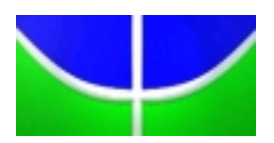

\author{
UNIVERSIDADE DE BRASÍLIA - UNB \\ INSTITUTO DE RELAÇÕES INTERNACIONAIS (IREL) \\ PROGRAMA DE PÓS-GRADUAÇÃO EM RELAÇÕES INTERNACIONAIS \\ (PPGRI)
}

\title{
FLUXOS MIGRATÓRIOS PARA O BRASIL NO INÍCIO DO SÉCULO XXI: RESPOSTAS INSTITUCIONAIS BRASILEIRAS
}

ÁTILA RABELO TAVARES DA CÂMARA

Brasília - DF 
FLUXOS MIGRATÓRIOS PARA O BRASIL NO INÍCIO DO SÉCULO XXI: RESPOSTAS INSTITUCIONAIS BRASILEIRAS

Dissertação apresentada no Programa de PósGraduação em Relações Internacionais da Universidade de Brasília, como requisito para obtenção do grau de Mestre em Relações Internacionais.

Orientador: Prof. Dr. Alcides Costa Vaz

Brasília - DF 


\section{FLUXOS MIGRATÓRIOS PARA O BRASIL NO INÍCIO DO SÉCULO XXI: RESPOSTAS INSTITUCIONAIS BRASILEIRAS}

Dissertação de Mestrado Aprovada pela Seguinte Comissão Examinadora:

Prof. Dr. Alcides Costa Vaz

Universidade de Brasília - IREL/UnB

Orientador
Prof ${ }^{\mathrm{a}}$. Dra ${ }^{\mathrm{a}}$. Tânia Maria Pechir Gomes Manzur
Universidade de Brasília - IREL/UnB
Examinadora

Prof. Dr. Leonardo Cavalcanti

Universidade de Brasília - CEPPAC/UnB

Examinador

Prof. Dr. Eitii Sato

Universidade de Brasília - IREL/UnB

Examinador (suplente) 
À minha família, meu precioso arroio,

sólida e firme base de apoio, para todas as minhas travessias. 


\section{AGRADECIMENTOS}

Ao Prof. Dr. Alcides Costa Vaz, por seu exemplo como educador e pesquisador, por seu comprometimento em favor da produção científica, por acreditar neste estudo e instigá-lo até que assumisse sua forma final.

À Prof ${ }^{a}$. Dr ${ }^{a}$. Tânia Maria Pechir Gomes Manzur, que gentilmente aceitou o convite para participar da Comissão Examinadora e incentivou, de forma significativa, que o estudo fosse erigido de modo mais consistente e enriquecedor, desde a etapa da qualificação.

Ao Prof. Dr. Leonardo Cavalcanti, que tanto contribuiu para meu despertar em relação à relevância de novas abordagens sobre o tema das migrações, aos desafios que a investigação científica propicia e aos novos horizontes acadêmicos que despontam diante de mim.

Ao Prof. Dr. Eitii Sato, por ter aceitado participar como suplente na Comissão Examinadora, e por ter fornecido contribuições para aprimoramento deste estudo.

A todos os professores do Programa de Pós-Graduação em Relações Internacionais, por ensinamentos e orientações que estimularam a busca contínua por novos conhecimentos no campo das ciências humanas aplicadas.

Aos participantes da pesquisa, que gentilmente se dispuseram a fornecer dados imprescindíveis à consecução deste estudo, relatando suas percepções acerca do fenômeno investigado.

Ao Anderson e à Odalva, funcionários da Universidade de Brasília, por sua solicitude e por seu auxílio na solução de questões administrativas.

Aos colegas da pós-graduação, por enriquecedores debates, discussões e apresentações ao longo do curso, e por seu companheirismo que sempre me impulsionou adiante.

Aos amigos Fábio Muller, Nara Reis, Vanessa Rezende, Weber Queiroz, Fabiano Coelho, Naomi Iwakiri, Gustavo García e Antônio Cardoso, que inspiraram a superação dos sacrifícios envolvidos na elaboração deste estudo, e incentivaram a sua conclusão de modo tão gratificante.

À Alessandra Matos, por sua amizade e por seu apoio atemporal.

Por fim, à minha família, a quem tanto amo, e ao Eterno, infindável fonte de luz e sabedoria. 
O mais importante é a mudança, o movimento, o dinamismo, a energia.

Só o que está morto não muda! Clarice Lispector

Outrora, eu era daqui, e hoje regresso estrangeiro, forasteiro do que vejo e ouço, velho de mim. Já vi tudo, ainda o que nunca vi, nem o que nunca verei.

Eu reinei no que nunca fui. Fernando Pessoa 


\section{RESUMO}

Este estudo investiga o fenômeno dos fluxos migratórios internacionais para o Brasil no início do século XXI, sobretudo em termos de desafios decorrentes desses fluxos para a atuação de instâncias governamentais brasileiras que operam nesse âmbito, com o objetivo de analisar quais medidas vêm sendo adotadas por tais instâncias, sob a forma de políticas migratórias, e de que modo podem ser avaliadas tais respostas institucionais - e se são fornecidas de modo coordenado ou não -, diante de demandas dos migrantes que participam desses fluxos. Particularmente, consideram-se as percepções dos dirigentes de unidades organizacionais em cinco instâncias governamentais diretamente envolvidas com a formulação e a implementação de políticas migratórias, as quais são analisadas conjuntamente com as percepções dos representantes de cinco organizações nãogovernamentais voltadas às migrações internacionais. Com base na literatura científica pertinente ao tema, são apresentadas e discutidas concepções acerca das migrações e de outros conceitos-chave, focalizando algumas das principais abordagens teóricas desenvolvidas sobre esse tema, em enfoque multidisciplinar, bem como o contexto sóciohistórico das migrações no Brasil. Foi realizada pesquisa qualitativa de caráter descritivo e explicativo, por meio de pesquisa documental e realização de entrevistas conforme roteiro com perguntas semi-estruturadas. Os resultados das entrevistas e da pesquisa documental possibilitaram a caracterização das percepções acerca dos fluxos migratórios para o Brasil no período considerado, bem como a categorização das respostas institucionais no contexto pesquisado em termos de: princípios norteadores das ações institucionais em torno das migrações; desafios ao desenvolvimento de ações institucionais frente às migrações; articulação e coordenação das ações entre instâncias governamentais; tendências em relação aos fluxos migratórios para o Brasil nos próximos anos; avaliação de iniciativas governamentais para políticas migratórias efetivas; e avaliação da atuação coordenada entre instâncias governamentais. Foram identificadas diversas lacunas que devem ser superadas com vistas a maior efetividade da atuação dessas instituições, bem como novas medidas adotadas que podem ser configurados como esforços em favor de nova política migratória. Conclui-se que as respostas institucionais do governo brasileiro diante das questões migratórias, embora tenham evoluído em termos de novos posicionamentos em relação ao tema, ainda carecem de articulação e coordenação mais estreita entre as várias instâncias, assim como de maior atenção ao acolhimento e à integração dos migrantes à sociedade brasileira, de modo que se salienta a necessidade de avançar nesse sentido para que haja aprimoramento na atuação dessas instâncias e maior efetividade das políticas migratórias brasileiras, bem como maior correspondência entre o discurso e a prática em torno da questão migratória no Brasil.

Palavras-chave: Migrante - Fluxos migratórios - Política de imigração 


\begin{abstract}
This study investigates the phenomenon of international migration flows to Brazil in the early twenty-first century, especially in terms of challenges arising from these flows for the performance of Brazilian government institutions operating in that context, in order to analyze what measures have been adopted by such instances in the form of migration policies, and how such institutional responses can be evaluated - and if they are provided in a coordinated way or not - considering demands of the migrants in these flows. In particular, it considers the perceptions of organizational units leaders in five government departments directly involved in the formulation and implementation of migration policies, which are analyzed altogether with the perceptions of representatives of five non-governmental organizations devoted to international migration. Based on the relevant scientific literature to the subject, concepts about migration are presented and discussed, as well as other key concepts, focusing on some of the main theoretical approaches developed on this topic, under multidisciplinary emphasis, as well as the socio-historical context of migration in Brazil. A qualitative research was carried out, considering descriptive explanatory methodological purposes, through documental research and interviews under script with semi-structured questions. The results of the interviews and documental research enabled the characterization of perceptions about migration flows to Brazil in the selected period, as well as the categorization of institutional responses on the researched context in terms of: guiding principles for institutional actions surrounding migration; challenges to the development of institutional front actions to migration; articulation and coordination of activities among government agencies; trends regarding migration flows to Brazil in the coming years; evaluation of government initiatives for effective migration policies; and evaluation of coordinated action between government agencies. A number of shortcomings have been identified that must be overcome in order to achieve greater effectiveness for the activities of these institutions, and there are new measures adopted that can be configured as efforts for new migration policy. It is concluded that the institutional responses of the Brazilian government on migration issues, although they have evolved in terms of new positions in relation to the subject, still require closer cooperation and coordination between the various agencies, as well as greater attention to the migrants reception and their integration to the Brazilian society. It is emphasized the need to move in this direction so that there is improvement in the performance of these agencies and greater effectiveness of Brazilian migration policies, as well as closer alignment between the discourse and practice around the issue of migration in Brazil.
\end{abstract}

Keywords: Migrant - Migratory flows - Immigration Policy 


\section{LISTA DE QUADROS}

Quadro 1. Passos para pesquisa empírica 49

Quadro 2. Repartição de competências entre instâncias governamentais ..................................... 53

Quadro 3. Percepções acerca dos fluxos migratórios para o Brasil no início do século XXI ...... 68

Quadro 4. Princípios norteadores das ações institucionais em torno das migrações .................... 73

Quadro 5. Desafios ao desenvolvimento de ações institucionais frente às migrações ................. 75

Quadro 6. Articulação e coordenação das ações entre instâncias governamentais ....................... 77

Quadro 7. Tendências em relação aos fluxos migratórios para o Brasil nos próximos anos ........ 81

Quadro 8. Avaliação de iniciativas governamentais para políticas migratórias efetivas .............. 84

Quadro 9. Avaliação da atuação coordenada entre instâncias governamentais ........................... 87 


\section{LISTA DE SIGLAS E ABREVIATURAS}

$\begin{array}{ll}\text { ACNUR } & \text { Alto Comissariado das Nações Unidas para Refugiados } \\ \text { CGIg } & \text { Coordenação-Geral de Imigração/MTE } \\ \text { CGPI } & \text { Coordenação-Geral de Polícia de Imigração/DPF } \\ \text { CNIg } & \text { Conselho Nacional de Imigração/MTE } \\ \text { CONARE } & \text { Comitê Nacional para Refugiados/MJ } \\ \text { COMIGRAR } & \text { Conferência Nacional sobre Migração e Refúgio } \\ \text { DEEST } & \text { Departamento de Estrageiros/MJ } \\ \text { DIJ } & \text { Departamento de Imigração e Assuntos Jurídicos/MRE } \\ \text { DIM } & \text { Divisão de Imigração/MRE } \\ \text { DPF } & \text { Departamento de Polícia Federal/MJ } \\ \text { IMDH } & \text { Instituto para Migrações e Direitos Humanos } \\ \text { MJ } & \text { Ministério da Justiça } \\ \text { MRE } & \text { Ministério das Relações Exteriores } \\ \text { MTE } & \text { Ministério do Trabalho e Emprego } \\ \text { OBMigra } & \text { Observatório das Migrações Internacionais (UnB) } \\ \text { OIM } & \text { Organização Internacional para as Migrações } \\ \text { OIT } & \text { Organização Internacional do Trabalho } \\ \text { ONU } & \text { Organizção das Nações Unidas } \\ \text { PNUD } & \text { Programa das Nações Unidas para o Desenvolvimento } \\ \text { PL } & \text { Projeto de Lei } \\ \text { PLS } & \text { Projeto de Lei do Senado } \\ \text { UnB } & \text { Universidade de Brasília }\end{array}$




\section{SUMÁRIO}

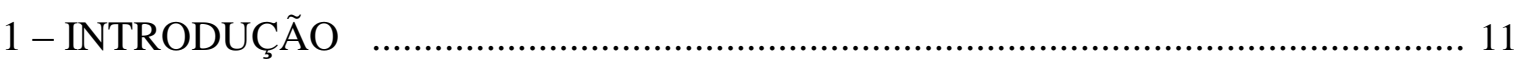

1.1- Contextualização do problema de pesquisa ………………………………………. 14

1.2 - Objetivos …………………………………………………………………... 17

1.2 .1 - Objetivo geral ………………………………………………….... 17

1.2 .2 - Objetivos específicos ………………………………………………….... 17

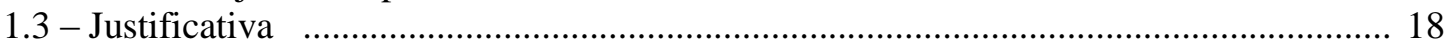

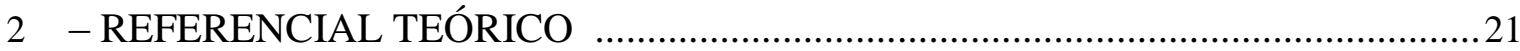

2.1 - Conceitos relevantes a respeito dos fluxos migratórios ............................................. 22

2.2 - Abordagens teóricas sobre o fenômeno das migrações internacionais ........................... 27

2.3 - Contexto histórico e sociopolítico das migrações internacionais para o Brasil ............. 38

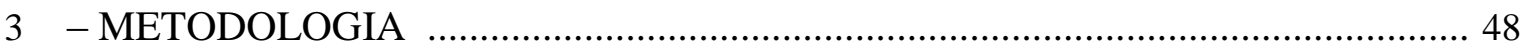

3.1 - Tipo e técnicas de pesquisa ……………………………………………………. 48

3.2 - Caracterização de organizações e de participantes da pesquisa …………………….... 50

3.3 - Procedimentos de coleta de dados ……………………………………………….... 58

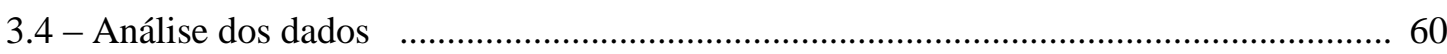

3.5 - Limitações da pesquisa ...………………………………………………………... 61

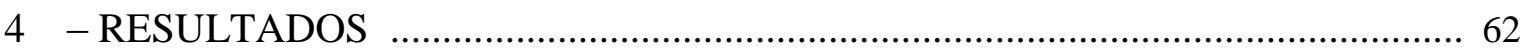

4.1 - O fenômeno migratório em perspectiva internacional ................................................ 62

4.2 - A imigração para o Brasil no início do século XXI ………………………………..... 66

4.3 - Percepções dos dirigentes de instâncias governamentais brasileiras .............................. 72

4.4 - Percepções dos representantes de organizações não-governamentais ............................. 83

4.5 - Esforços em favor de uma nova política migratória …………………………………….. 89

4.5.1 - Projetos de reforma do marco normativo sobre estrangeiros ................................... 90

4.5.2 - Atuação do CNIg na formulação de políticas migratórias ....................................... 92

4.5.3 - Perspectivas decorrentes da I Comigrar .............................................................. 94

5 - CONSIDERAÇÕES FINAIS .......................................................................... 99

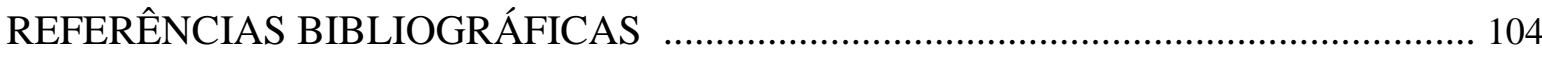

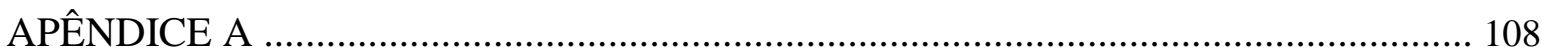

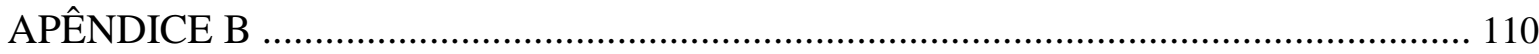

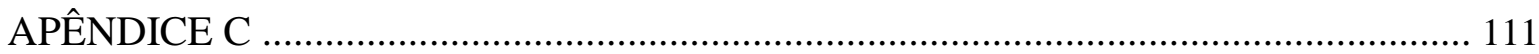




\section{Introdução}

Este estudo se consiste de uma investigação sobre o tema dos fluxos de migração de pessoas para o Brasil no início do século XXI, no ensejo de identificar suas origens, causas, características e tendências, bem como de apontar os principais desafios que tais movimentos recentes podem representar para a atuação de instituições governamentais brasileiras no âmbito das migrações internacionais.

No âmbito deste estudo, a expressão 'fluxo migratório' faz referência ao movimento de entrada (imigração) e saída (emigração) de pessoas. O indivíduo que participa do fluxo migratório internacional é o migrante, ou seja, aquele que deixou seu país ou região de moradia por um período de tempo relativamente longo, com o objetivo de fixar residência no país ou região de destino, em caráter temporário ou definitivo (LOPES, 2009). Nos últimos anos, o tema das migrações tornou-se mais complexo, diante da diversificação e da intensificação dos fluxos migratórios em escala global, e há um amplo conjunto de abordagens sobre o assunto (SAYAD, 1998; MASSEY et al., 1993; CASTLES; MILLER, 2009; CAVALCANTI, 2005; SILVA, 2005; BAENINGER, 2008; BASSANEZI et al., 2008; LOPES, 2009), as quais decorrem de diversas perspectivas e interesses envolvidos.

Fluxos migratórios são particularmente relevantes no contexto da globalização, pois com o deslocamento de pessoas também ocorre o deslocamento de informações econômicas, sociais, políticas e culturais, as quais afetam diretamente diversas variáveis da conjuntura nacional e internacional. Com maiores interações entre os mais diversos atores na esfera social, política, econômica e cultural, as trocas - de informações, recursos etc. - se intensificam e se aceleram, exercendo forças de atração e/ou repulsão que vêm culminando na ampliação dos fluxos de pessoas entre grante parte dos países e regiões.

Adicionalmente, como argumentam Martinucci e Milesi (2005, p.1), as migrações internacionais "constituem um espelho das assimetrias das relações socioeconômicas vigentes em nível planetário, [tais como] termômetros que apontam as contradições das relações internacionais e da globalização". Desse modo, os fluxos migratórios podem sugerir movimentos desencadeados por marcantes distinções entre os mais diversos países e regiões a respeito de disparidades no acesso a renda, emprego, respeito aos direitos políticos, liberdade religiosa, bem-estar social, dentre outros fatores. 
A esse respeito, Batista (2009) salienta que o contexto da globalização tem atuado diretamente sobre o formato das migrações internacionais, especialmente quanto às migrações em massa, à circulação de pessoas no ambiente internacional, aos processos de seleção e às restrições impostas às entradas de migrantes. Por outro lado, aponta que:

(...) essas migrações continuam produzindo o efeito de sempre: agregam pessoas e riquezas e resultam, naturalmente, em novas estratégias e mudanças comportamentais dos grupos sociais envolvidos. Se estas influências serão negativas ou positivas dentro de um Estado, afetando a modificação dos textos legais e efetivando direitos dos migrantes, bem como suas condições de vida, dependerá da escolha teórica e política de cada Estado (BATISTA, 2009, p.77).

Cabe salientar a emergência de um contexto político e econômico que caracteriza o cenário internacional ao longo dos últimos anos, o qual decorre de marcantes acontecimentos que afetaram a ordem mundial, tais como: a ocorrência dos atentados perpetrados em setembro de 2001, nos Estados Unidos, e suas consequências em termos de novas barreiras, restrições e mecanismos de controle no âmbito da migração de pessoas em escala global; o advento de crise financeira que acomete desde 2008 algumas das principais economias mundiais; a criação e a ampliação de acordos com vistas à livre circulação de pessoas entre nações integrantes de comunidades de países, e os desafios sociopolíticos e econômicos para sua implementação; os desdobramentos de mudanças demográficas, culturais e de acesso à informação e à tecnologia, que contribuem para a comunicação, a aproximação e a migração de pessoas e grupos ao redor do globo, embora também possam desencadear ou acirrar reações de aversão, resistência e tensão entre contingentes de nacionais e de migrantes.

O Brasil, que historicamente é apontado como um país de predominante tendência imigratória (SILVA, 2005), tem apresentado em décadas recentes considerável elevação no fluxo de emigração de seus nacionais. No decorrer da última década, há indícios de que tanto o fluxo imigratório como o fluxo emigratório têm se intensificado no tocante ao Brasil, de modo que muitos brasileiros têm deixado seu país para viver no exterior, ao mesmo tempo em que o país tem atraído diversos contingentes de estrangeiros em busca de melhores condições de vida e oportunidades de trabalho.

Diante do exposto, almeja-se, por meio deste estudo, a identificação dos principais aspectos que caracterizam os fluxos migratórios internacionais para o Brasil ao longo dos últimos dez anos, bem como a caracterização das ações governamentais direcionadas ao atendimento das demandas inerentes a esses movimentos migratórios, buscando identificar origens, causas, tendências e desafios que decorrem desses fluxos para a atuação coordenada 
de órgãos e instâncias governamentais brasileiras que atuam no âmbito da migração de pessoascomo alguns dos principais formuladores e/ou implementadores de políticas migratórias no Brasil. Dentre tais órgãos e instâncias governamentais cuja atuação é objeto desta investigação, incluem-se: o Ministério da Justiça (MJ), por meio do Departamento de Estrangeiros (DEEST); o Ministério das Relações Exteriores (MRE), em seu Departamento de Imigração e Assuntos Jurídicos (DIJ) e sua Divisão de Imigração (DIM); o Ministério do Trabalho e Emprego (MTE) e sua Coordenação-Geral de Imigração (CGIg); o Conselho Nacional de Imigração (CNIg), como unidade organizacional na estrutura do MTE; e o Departamento de Polícia Federal (DPF), por meio de sua Coordenação-Geral de Polícia de Imigração (CGPI), como autarquia subordinada ao MJ.

A atuação dessas instâncias governamentais e as respostas institucionais fornecidas para as demandas dos migrantes foram consideradas, também, sob a perspectiva de representantes de cinco entes não-governamentais que atuam diretamente em torno dos fluxos migratórios. Dentre tais entes, três correspondem a escritórios regionais de organismos internacionais: a Organização Internacional do Trabalho (OIT); a Organização Internacional para as Migrações (OIM), ainda em processo de instalação no Brasil; e o Alto Comissariado das Nações Unidas para Refugiados (ACNUR). E outros dois correspondem a organizações da sociedade civil em apoio aos migrantes: o Instituto para Migrações e Direitos Humanos (IMDH), em Brasília, e a Missão Paz, em São Paulo, que fazem parte da Pastoral do Migrante e da Rede Caritas de atenção à pessoa migrante. Todas essas instituições também exercem certo grau de influência na formulação da política migratória brasileira, na medida em que têm acesso a fóruns e discussões acerca do tema.

Quanto ao estudo, encontra-se estruturado conforme descrito a seguir. A primeira parte, introdutória, contextualiza o tema e discorre acerca dos objetivos propostos. A segunda parte considera referências teóricas relevantes para a compreensão dos principais conceitos e aspectos pertinentes aos movimentos de migração de pessoas em escala internacional, bem como seus desafios às instituições responsáveis pela regulamentação e pelo acompanhamento desses movimentos. Traz, ainda, uma contextualização histórica e sociopolítica a respeito de fenômeno das migrações para o Brasil. Em seguida, a terceira parte discorre acerca da metodologia proposta para investigação dos fluxos migratórios internacionais para o Brasil no decorrer da última década.

A quarta parte apresenta os resultados da pesquisa, examinando os movimentos migratórios para o Brasil no início do século XXI e as respostas institucionais às demandas 
ds migrantes, mediante a delimitação de algumas categorias de análise, e levando em conta esforços empreendidos institucionalmente para a definição de novas políticas migratórias no Brasil. Por fim, as conclusões do estudo são reunidas à guisa de considerações finais.

\section{1 - Contextualização do Problema de Pesquisa}

A mobilidade humana é um dos temas das relações internacionais contemporâneas que têm recebido cada vez mais atenção por parte de investigadores. Nesse contexto, o tema pode ser considerado como estratégico tanto por governos nacionais como por organismos internacionais, visto que os movimentos migratórios acarretam transformações sociais, culturais, econômicas e legais, tanto nos países de destino como de origem.

Nesse sentido, as migrações internacionais podem ser vislumbradas tanto como uma experiência humana quanto como um fenômeno sociocultural, econômico e político que conforma a história de diferentes sociedades. Como argumentam Cogo e Souza (2013), os movimentos e fluxos migratórios são dinâmicos e assumem especificidades em diferentes etapas e momentos históricos, de modo que as autoras mencionam a relevância em se analisar conjunturalmente as marcas e os impactos do fenômeno das migrações em relação ao contexto histórico e social.

Múltiplos fatores podem influenciar diretamente tais fluxos e ciclos migratórios em todo o mundo, tais como: eclosão de guerras, regimes ditatoriais, crises econômicas, calamidades ambientais, carências de recursos, políticas de incentivo ou repressão às migrações. Cabe lembrar ainda que fatores econômicos, tais como a busca de trabalho e a fuga de situações de pobreza, são importantes impulsionadores dos fluxos migratórios globais, o que contribui para se compreender por que esses fluxos têm se dirigido prioritariamente a determinados países e regiões que apresentam maior grau de desenvolvimento. Além disso, as próprias redes migratórias (MASSEY et al. 1993; GURAK; CACES, 1998) operam como espaços de interação entre os migrantes, de modo a colaborar para a constituição, ampliação ou reforço de determinadas rotas e movimentos de migração entre nações ou regiões.

O Relatório de Desenvolvimento Humano de 2009, elaborado pelo Programa das Nações Unidas para o Desenvolvimento (PNUD), considera que, a respeito das tendências globais de movimento, os fluxos migratórios refletem a necessidade que as pessoas têm de buscar melhores condições de vida. De acordo com o referido relatório, uma em cada cinco 
pessoas no mundo se encontra em situação migratória, interna ou externamente em relação ao território de seu país. O estudo aponta que há mais de um bilhão de migrantes ao redor do globo, estimando que 200 milhões se movimentam internacionalmente.

Com a crise econômica desencadeada em 2008, a qual vem afetando de modo relevante os Estados Unidos, o Japão e países da Europa (como Espanha e Portugal, entre outros), tais regiões passaram a apresentar significativa emigração de contingentes populacionais, ao mesmo tempo em que o Brasil e outros países em desenvolvimento passaram a vivenciar crescimento dos fluxos migratórios oriundos de outros países da América Latina, da Europa, da Ásia e da África.

Nesse cenário de crise global, deve-se levar em conta o retorno significativo de imigrantes sul-americanos, dentre os quais se situam brasileiros que compõem contingentes de imigrantes de retorno de países como Portugal, Espanha, Estados Unidos e Japão, contextos que haviam se transformado em décadas anteriores nos principais destinos da emigração brasileira ao exterior. Por conta desse incremento da imigração para o Brasil e do retorno de brasileiros junto de seus familiares, as instâncias governamentais e as organizações de apoio aos migrantes se voltam à discussão sobre a necessidade de definição de políticas migratórias que atendam às necessidades de inserção e de acolhimento desses novos fluxos que chegam ao país.

De acordo com dados do MJ, entre janeiro e junho de 2013, mais de 40 mil profissionais estrangeiros (temporários e permanentes) obtiveram permissão para trabalhar no país. Dados do MTE revelam que, em 2013, cresceu em 3,5\% o número de vistos de trabalho concedido a estrangeiros no Brasil, o que não inclui o número de imigrantes que não dispõem vistos de trabalho, nem daqueles que não conseguiram a regularização jurídica.

Apesar disso, a OIM estima que ainda há muitos migrantes em situação irregular no país. Como ainda não possuem documentos necessários à estada regular; são denominados, dessa forma, como migrantes 'não documentados'. Um relatório elaborado (OIM, 2011) aponta que, além do tradicional fluxo migratório entre os países da América Latina, que aumentou sensivelmente nos últimos anos, o Brasil tem recebido considerável contingente de estrangeiros da África subsaariana, de países do Sul da Ásia e do Haiti.

Os haitianos, particularmente, correspondem a um dos fluxos migratórios recentes que vem se intensificando no Brasil, sobretudo após o terremoto que atingiu o Haiti em 2010 e o início da participação brasileira na força de paz internacional enviada ao país. De acordo com relatório da OIM acerca do influxo de haitianos no Brasil, muitos desses migrantes 
ingressam no território nacional pela fronteira com a Bolívia e o Peru, com rotas que atravessam o Equador e a Colômbia, muitas vezes em situação clandestina e sujeitos a vulnerabilidades sociais e graves riscos (OIM, 2011).

Em termos de política migratória brasileira, embora não se encontre como tal expressa de modo coeso, podem ser apontadas algumas medidas adotadas por instâncias governamentais que operam nesse âmbito, tais como: acordo regional com países do Mercosul para facilitar migrações entre os países da região; assinatura de compromissos para acolhimento de refugiados; realização de anistias para estrangeiros em situação irregular a cada década, sendo que a última ocorreu em 2009; estímulo ao ingresso de mão-de-obra qualificada para suprir vagas no mercado laboral; exercício do controle de fronteiras aliado a sistema de vistos; aplicação do princípio da reciprocidade para isenção da necessidade de vistos com vistas a ingresso e permanência de estrangeiros no país etc. Não obstante, a execução de tais medidas por uma multiplicidade de atores aparenta, por vezes, certo grau de desconexão, e não raro há distintos entendimentos a respeito de sua concretização.

Em estudo sobre as migrações para o Brasil, Assad (2012) ressalta que as medidas de política migratória são acometidas pela defasagem normativa, uma vez que ainda são definidas pelo Estatuto do Estrangeiro (Lei $n^{\circ}$ 6.815) em vigência desde 1980. Assim, embora haja uma política de Estado para normatizar o trânsito migratório e recepcionar os migrantes, a autora argumenta que "não temos políticas públicas para a integração dos migrantes estrangeiros, que quanto mais empobrecidos são, mais vulneráveis e sujeitos a constrangimentos econômicos e sociais ficam" (ASSAD, 2012, p.30).

Observa-se, dessa maneira, que o Brasil se depara com o desafio de aprimorar esforços em torno da questão dos contingentes de migrantes que se deslocam para o território nacional, em número que se eleva gradativamente a cada ano. Ademais, Assad (2012) salienta que o país precisa se adaptar a esse fluxo crescente de pessoas, em grande parte buscando oportunidades de inserção social e melhoria de suas condições de vida. Tal desafio envolve, ademais, a otimização da atuação das instâncias governamentais envolvidas, as quais devem ser capazes de fornecer respostas em torno de políticas públicas aptas a lidar com os contingentes de migrantes provenientes do contexto internacional.

Acerca de estudos sobre a questão dos fluxos migratórios no Brasil, pode ser conferida especial atenção aos estudos desenvolvidos por Silva (2005), Cavalcanti (2005), Cervo (2008), Baeninger (2008, 2013), Bassanezzi et al. (2008), Batista (2009), Lopes (2009), Assad (2012) e Dutra (2013), envolvendo pertinentes reflexões a respeito dos 
eventos que motivam tais fluxos migratórios do e para o Brasil, bem como acerca de consequências desses fluxos para o contexto nacional. Salienta-se, acima de tudo, o interesse crescente que o tema vem recebendo por parte dos pesquisadores.

A maioria destas abordagens considera, como argumenta Cervo (2008, p.180), os "piques de imigração e de emigração" no Brasil, fazendo referência à influência do contexto histórico em torno dos movimentos migratórios, bem como ao âmbito das relações internacionais, sobretudo a partir do século XX, entremeando-se à trajetória política, econômica e social do país nesse período.

Considerando o exposto, almeja-se, no contexto dos fluxos migratórios para o Brasil, e considerando a atuação das instituições brasileiras que operam nesse âmbito, bem como seus principais desafios, responder ao seguinte problema de pesquisa: quais são e como podem ser avaliadas as medidas que vêm sendo implementadas por instituições governamentais brasileiras que atuam no âmbito das migrações internacionais, de modo a responder as demandas decorrentes dos movimentos migratórios para o Brasil no início do século XXI?

Dessa forma, essa pergunta sugere a hipótese de que há influência, para a efetividade dessas medidas, do grau de coordenação e complementaridade na atuação das organizações governamentais brasileiras na área de migração de pessoas, e que disfunções nessa coordenação podem afetar consideravelmente o desenvolvimento e a implementação de políticas em torno das migrações para o Brasil. Assim, em torno desse problema de pesquisa e dessa hipótese, almeja-se examinar qual a resposta institucional do Brasil frente a demandas decorrentes dos fluxos migratórios contemporâneos, bem como caracterizar a atuação dessas instituições brasileiras que operam no âmbito dos movimentos migratórios, com enfoque na articulação e na coordenação de seus programas e de suas ações.

\section{2 - Objetivos}

\subsection{1 - Objetivo geral}

O objetivo geral deste estudo é o de examinar medidas implementadas por instituições governamentais brasileiras que atuam no âmbito das migrações internacionais, de modo a responder as demandas decorrentes dos movimentos migratórios para o Brasil no início do século XXI. 


\subsection{2 - Objetivos específicos}

Como objetivos específicos, pretende-se:

- Caracterizar os principais fluxos migratórios internacionais para o Brasil ao longo dos últimos dez anos, apontando suas origens, o perfil de seus participantes e seus aspectos mais relevantes;

- Descrever aspectos pertinentes a políticas para migração de pessoas no Brasil, assinalando princípios e diretrizes que orientam a atuação das instituições brasileiras no âmbito da migração de pessoas;

- Inter-relacionar dados obtidos por meio de pesquisa documental e de entrevistas acerca da atuação de unidades do Ministério das Relações Exteriores, do Ministério da Justiça e do Ministério do Trabalho e Emprego, em torno da ação institucional de organizações governamentais brasileiras no âmbito da migração de pessoas;

- Avaliar o grau de articulação e de coordenação entre instituições brasileiras que operam nessa área e sua capacidade de fornecer respostas efetivas diante de demandas decorrentes dos fluxos migratórios contemporâneos, identificando suas principais tendências e desafios.

\section{3 - Justificativa}

Nas últimas décadas, os fluxos econômicos, financeiros, informacionais e migratórios se intensificaram em escala global. De acordo com o World Economic and Social Survey, um informe do Departamento de Assuntos Econômicos e Sociais da ONU para o ano de 2004, cerca de três por cento da população mundial naquele ano viviam fora do país em que nasceram, de modo que "as migrações já estão criando enormes tensões econômicas, políticas, culturais e religiosas nas sociedades dos países desenvolvidos" (ONU, 2004, p.37-38). O informe menciona que pode ser limitada a extensão com que tais sociedades possam receber influxos de novos trabalhadores migrantes.

Salienta-se, no âmbito dos fluxos migratórios internacionais, o contexto de posicionamentos e compromissos internacionais assumidos em prol da ampliação e da efetivação dos Direitos Humanos aos migrantes, o que se reflete na transformação do papel 
dos Estados Nacionais e das políticas públicas em relação aos processos internacionais de distribuição da população no espaço (COGO; SOUSA, 2013). A comunidade internacional, assim, se volta cada vez mais a debater a questão dos fluxos migratórios e a situação dos migrantes, bem como os impactos desses deslocamentos sobre o contexto local e regional.

Como argumenta Baeninger (2008), as migrações internacionais no século XXI adquirem, cada vez mais, papel importante no cotidiano social, nos mercados de trabalho, nas sociedades de chegada e de partida, nos fluxos financeiros, na mobilidade da força de trabalho e na vida das populações migrantes, como parte integrante do desenvolvimento que reflete e que é refletida na divisão internacional do trabalho. A esse respeito, salienta Vainer (2007) que a imigração, em geral, vem se tornando mais politizada, e que os posicionamentos acerca dos imigrantes não-documentados têm sido colocados à frente dos debates que envolvem questões migratórias.

A respeito dos migrantes não-documentados, Moreira e Oliveira (2013) salientam situações de vulnerabilidade social a que se encontram submetidos em suas travessias, de modo que os locais em que se instalam não raro possuem precária infraestrutura que não lhes confere padrões mínimos de saúde e bem-estar. Nesse sentido, as autoras salientam que muitas vezes "os imigrantes tendem a se tornar o grupo mais vulnerável da população, carecendo de estruturas básicas de vida” (MOREIRA; OLIVEIRA, 2013, p.10).

Adicionalmente, deve-se levar em conta as tensões entre os níveis de ação internacional, nacional e local, bem como a noção de que os movimentos migratórios internacionais constituem a contrapartida da reestruturação territorial entre países e continentes, de modo intrinsecamente relacionado à reestruturação econômico-produtiva em escala global (PATARRA, 2005).

Como argumenta Bizerril (2012), o exemplo mais evidente dessas tensões é:

o contrafluxo do processo de colonização: as migrações maciças de populações das ex-colônias em direção às nações hegemônicas (...). Obviamente, este movimento tem sido objeto de crescente restrição pelo menos desde o incidente de 11 de setembro de 2001, que inaugurou uma ruptura nos rumos que a globalização tinha tomado até então, justificando o fechamento de fronteiras inicialmente com o argumento da segurança, em particular da guerra ao terror. A última década assistiu a uma intensificação deste processo, com uma explicitação de sua dimensão xenofóbica e econômica (BIZERRIL, 2012, p.17).

Tais aspectos culminam em contínuos desafios às instituições que atuam em âmbito internacional e também à comunidade acadêmica, como mencionam Marinucci e Milesi (2005). Particularmente, o tema é relevante para órgãos públicos nacionais e também para organismos internacionais, bem como para centros de estudos migratórios e grupos de 
estudos sobre esse tema ao redor do globo, cujas investigações podem contribuir para a análise do fenômeno, sobretudo em perspectiva multidisciplinar nos campos político, sociológico, econômico e jurídico, culminando em formulação de políticas públicas que proporcionem a efetividade da ação governamental nas questões de migração.

Dessa forma, o estudo investiga a atuação de órgãos e instâncias governamentais brasileiras diante de fluxos migratórios internacionais para o Brasil ao longo da última década, destacando suas principais características e identificando desafios que decorrem de tais fluxos para a ação coordenada de instituições que atuam no âmbito da migração de pessoas. Espera-se, assim, fornecer um diagnóstico da resposta institucional a esses movimentos de migração para o Brasil ao longo dos últimos anos, e apontar de que forma o Estado brasileiro formulou políticas, estabeleceu normas e planejou o desenvolvimento de ações para lidar com os desafios decorrentes dos fluxos migratórios.

Tradicional país que recebe migrantes provenientes de diversas partes do globo (LOPES, 2009), o Brasil trata, no presente momento, de apreciar no Congresso Nacional o Projeto de Lei - PL n⿳ 5.655/2009, que dispõe sobre o ingresso e permanência de estrangeiros no território nacional, o instituto da naturalização e as medidas compulsórias, além de transformar o Conselho Nacional de Imigração (CNIg) em Conselho Nacional de Migração. Outras propostas de revisão são o Projeto de Lei do Senado - PLS no 288/2013, bem como a Portaria $n^{\circ}$ 2.162/2013, do MJ, como anteprojeto de nova lei para as migrações.

Nesse contexto, presume-se que tais propostas de mudança no marco regulatório sobre as migrações no Brasil, bem como os impactos dos fluxos migratórios para o Brasil nos últimos anos, culminam em alterações que afetam a atuação das instituições públicas brasileiras que operam junto à migração de pessoas, particularmente no âmbito de unidades do MRE, do MJ e do MTE. Daí se fundamenta a proposição deste estudo, objetivando investigar como tais instâncias têm atuado diante dos fluxos migratórios para o Brasil nos últimos anos, bem como quais os desafios para a atuação conjunta dessas instituições.

É oportuno salientar, ainda, o argumento aclamado por Marinucci e Milesi (2005), de que as migrações correspondem a fontes de inovações e de transformações, de modo que podem gerar tanto solidariedade como discriminação, tanto encontros como choques, e tanto acolhida como exclusão. Ressalta-se, assim, como dever da comunidade internacional, em geral, e das instituições públicas, em particular, fazer com que novos elementos trazidos pelos migrantes sejam fonte de enriquecimento recíproco na construção de uma cultura de paz e justiça social. 


\section{2 - Referencial Teórico}

A crescente importância das migrações internacionais tem sido, efetivamente, objeto de um número expressivo de contribuições importantes, de caráter teórico e empírico, que atestam sua diversidade, significados e implicações. Por meio de uma análise dos fluxos migratórios internacionais, remete-se, assim, a uma reflexão sobre transformações econômicas, sociais, políticas, demográficas e culturais que se processam em âmbito internacional, no decorrer das últimas décadas.

A respeito dos desenvolvimentos teóricos em torno da temática dos fluxos migratórios na literatura pertinente em contexto internacional, cabe salientar a relevância de estudos tidos como seminais por pesquisadores do tema, de fundamental importância para erigir os fundamentos da investigação proposta. Dentre tais obras, podem ser mencionadas as abordagens teóricas de Sayad (1998), Sassen (1980), Massey et al. (1993), Castles e Miller (2009), Portes (1999), dentre outros. Adicionalmente, salienta Cavalcanti (2005, p.37) que essa é uma questão que vem ocupando continuamente as principais pautas nas agendas de governos e organismos internacionais, de modo que "o fenômeno migratório ganhou um protagonismo singular no cenário internacional”.

Os movimentos migratórios internacionais contemporâneos se caracterizam por serem mais que fenômenos sociais, pois têm um forte componente político expresso, sobretudo, na organização dos Estados e na formação de organismos em âmbito internacional. Como argumenta Batista (2009), essa situação se confunde com a própria questão dos direitos humanos, que se impõe sobre a discussão das migrações de pessoas, conforme as perspectivas política, econômica, jurídica, histórica e até mesmo filosófica. Como argumenta Bizerril (2012, p.17), "a despeito da especificidade do recorte da pesquisa de um determinado investigador, o tema das migrações globais é atravessado por questões simultâneas que não pertencem exclusivamente a nenhum campo disciplinar em particular".

Nesse sentido, pelo caráter multidisciplinar que caracteriza tal enfoque, consideramse os campos de conhecimento das Ciências Sociais, das Ciências Econômicas, da Geografia, da História e das Relações Internacionais como alguns dos mais apropriados para a consecução de pesquisas capazes de explicar e descrever tal fenômeno. Para tanto, faz-se necessário delimitar de que forma esse tema se insere e se inter-relaciona no âmbito desses campos de conhecimento, seus enfoques, suas abordagens e seu contexto sócio-histórico. 
A respeito de tais movimentos, é também oportuno fazer referência ao fenômeno da globalização, não apenas em termos dos fluxos de mercadorias e finanças, como também em termos dos fluxos de pessoas entre países, regiões e continentes. Cabe salientar que o termo globalização não tem uma definição única e universalmente aceita. De acordo com Held e McGrew (2001, p. 11), a globalização pode ser concebida como:

(...) ação à distância (quando os atos de agentes sociais de um lugar podem ter
consequências significativas para "terceiros distantes"); como compressão espaço-
temporal (numa referência ao modo como a comunicação eletrônica instantânea
vem desgastando as limitações da distância e do tempo na organização e na
interação sociais); como interdependência acelerada (entendida como a
intensificação do entrelaçamento entre economias e sociedades nacionais, de tal
modo que os acontecimentos de um país têm um impacto direto em outros); como
um mundo em processo de encolhimento (erosão das fronteiras e das barreiras
geográficas à atividade socioeconômica).

Considerando os argumentos de Patarra (2005) a respeito da globalização, a complexidade que caracteriza as recentes tendências de movimentos migratórios internacionais vem demandando a avaliação de paradigmas para ser compreendida de modo mais coerente. Para tanto, a autora argumenta que "tornam-se imprescindíveis a incorporação de novas dimensões explicativas e uma revisão da própria definição do que é o fluxo migratório" (PATARRA, 2005, p.24).

É nessa perspectiva, particularmente, que se ressaltam rumos e direções tomados no âmbito de políticas referentes a fluxos migratórios de pessoas entre países, regiões e continentes, em escala global, de modo que tais políticas apontam interesses comuns dos principais atores institucionais envolvidos, em âmbito nacional e internacional, e denotam concepções e significados compartilhados em torno dos aspectos sociopolíticos e econômicos associados a tais movimentos migratórios. Para tanto, é oportuno salientar de que forma são compreendidos tais conceitos, tidos como relevantes no âmbito dos movimentos migratórios.

\section{1 - Conceitos relevantes a respeito dos fluxos migratórios}

A literatura pertinente ao tema aponta que a migração sempre foi um elemento básico da condição humana, e que atualmente reflete questões individuais e coletivas que colocam à prova o próprio funcionamento do Estado. De acordo com Batista (2009), a relação entre a migração e o fato de se pertencer a um determinado Estado é ambígua: por um lado, envolve o encorajamento para que o indivíduo exerça sua liberdade de ir e vir; por outro lado, a ideia 
de pertencer a um Estado significa também uma estreita conexão com o território e as pessoas sob poder estatal.

O termo 'nacionalidade', assim, diz respeito à condição própria do cidadão de um país, por naturalidade ou naturalização. Lopes (2009), fazendo referência a entendimento da Corte Interamericana de Direitos Humanos, argumenta que nacionalidade também pode ser definida como "o vínculo jurídico político que liga uma pessoa com um Estado determinado por meio do qual se obriga com ele em relações de lealdade e fidelidade, e se faz credor de sua proteção diplomática" (LOPES, 2009, p.126).

A questão das migrações internacionais envolve, assim, tanto o vínculo do indivíduo com o país da morada quanto com sua comunidade política original. A esse respeito, Batista (2009, p. 8) argumenta que:

(...) não se trata, portanto, da simples transferência de uma comunidade política
para outra, mas de todo um processo de inclusão e aceitação em outro território e
no seio de outra comunidade política, nem sempre receptiva ou disposta a aceitar
novos membros em suas atividades econômicas, políticas, sociais, culturais etc.
Assim, embora haja nos textos internacionais e nas constituições contemporâneas a
promessa de igualdade jurídica e de democracia republicana, a ausência de uma
ligação formal da pessoa ao território no qual escolheu viver, ou foi forçado a se
instalar, pode lhe negar qualquer sentido de cidadania e, portanto, capacidade de
participar de qualquer forma positivada de democracia no país de acolhida.

Quanto à 'migração', Castles e Miller (2009, p.20) a caracterizam como “uma ação coletiva, que envolve mudança social e que afeta toda a sociedade tanto nas regiões que enviam seus nacionais como nas regiões que os recebem”. Segundo os autores, a ideia de processo migratório contribui para exprimir o complexo conjunto de fatores e interações que levam à migração internacional, e que influenciam seu curso, de modo que as mudanças são geralmente contundentes para os próprios migrantes, e podem ser vislumbradas em todos os estágios do processo migratório, seja nos países de origem, de trânsito ou de destino.

No âmbito desse estudo, a expressão 'fluxo migratório' faz referência ao movimento de entrada (imigração) e saída (emigração) de pessoas. O indivíduo que participa do fluxo migratório internacional é o 'migrante', aquele que deixou seu país ou região de moradia por um período de tempo relativamente longo, com o objetivo de fixar residência na região, em caráter temporário ou definitivo. Ou seja, o imigrante é "a pessoa que imigra, que entra em um país estrangeiro para aí viver" (LOPES, 2009, p.32).

Haesbaert (2006, p.246) argumenta que o termo migrante diz respeito a "uma categoria muito complexa e, no seu extremo, (...) há tantos tipos de migrantes quanto de indivíduos ou grupos sociais envolvidos nos processos migratórios". Por conta disso, o autor 
opta por caracterizar o migrante em termos de "uma entidade abstrata [que] é, na verdade, um somatório das mais diversas condições sociais e identidades étnico-culturais" (HAESBAERT, 2006, p.246).

Sayad (1998, p.54-55), por sua vez, compreende o imigrante como:

(...) essencialmente uma força de trabalho, e uma força de trabalho provisória, temporária, em trânsito. (...) Afinal, um imigrante só tem razão de ser no modo do provisório e com a condição de que se conforme ao que se espera dele; ele só está aqui e só tem sua razão de ser pelo trabalho e no trabalho; porque se precisa dele, enquanto se precisa dele, para aquilo que se precisa dele e lá onde se precisa dele.

Dessa forma, percebe-se que há concepções distintas acerca do mesmo fenômeno, de modo que a concepção de Sayad (1998) a respeito do fenômeno da imigração pressupõe uma diferença fundamental entre o migrante (que cruza fronteiras voluntariamente no sentido de buscar melhores condições de vida a partir da oferta de sua mão-de-obra, ainda que de forma informal e não documentada), o refugiado (por meio de deslocamentos forçados, buscando afastar-se de situações de risco social decorrentes de perseguições, calamidades, guerras e vulnerabilidades extremas) e o asilado (que envolve a saída de indivíduos do território de seu próprio país em decorrência de fatores de ordem política).

Pressupõe-se, adicionalmente, distinção entre o termo 'imigrante' e 'estrangeiro', tal como mencionada por Sayad:

Um estrangeiro, segundo a definição do termo, é estrangeiro, claro, até as fronteiras, mas também depois que passou as fronteiras; continua sendo estrangeiro enquanto puder permanecer no país. Um imigrante é estrangeiro, claro, até as fronteiras, mas apenas até as fronteiras. Depois que passou a fronteira, deixa de ser um estrangeiro comum para tornar-se um imigrante. Se "estrangeiro" é a definição jurídica de um estatuto, "imigrante" é antes de tudo uma condição social (SAYAD, 1998, p.243).

Conforme salientado por Lopes (2009, p.32), o termo 'imigrante' indica "movimento, ação, muito embora a condição de imigrante permaneça após concluído o ato de imigrar". Assim, seu conteúdo expressa uma situação social, enquanto o termo 'estrangeiro' estaria mais vinculado a uma situação jurídica. Nesse sentido, a autora caracteriza o imigrante como "o estrangeiro que permanece" (LOPES, 2009, p.32).

Por sua vez, Téllez (2003, p.209) compreende 'rota migratória' como “um padrão de recorrências de deslocamentos humanos entre dois conjuntos de espaços geográficos que representam as zonas de chegada e de saída". Assim, rota migratória diz respeito ao trajeto seguido pela pessoa migrante, ou pelo grupo de migrantes, ao deslocar-se entre as fronteiras 
dos países, considerando países e regiões de origem, de passagem e de destino, bem como os meios de transporte empregados e os recursos investidos para efetuar a travessia.

Em termos das motivações para migrar, Haesbaert destaca que:

\begin{abstract}
há migrações ditas econômicas vinculadas à mobilidade pelo trabalho, migrações provocadas por questões políticas e outras por questões culturais ou ainda ambientais. Para completar, categorias como as de refugiado e asilado muitas vezes são confudidades com a de migrante, sendo muitas as situações ambíguas ou de entrelaçamento. (...) O migrante que se desloca antes de tudo por motivos econômicos, imerso nos processos de exclusão socioeconômica, pode estar deixando um emprego mal remunerado para buscar outro com remuneração mais justa, pode estar querendo usufruir ganhos pela diferença de poder aquisitivo da moeda de um país em relação a outro, ou ainda, simplesmente, para aqueles numa condição muito mais privilegiada, pode estar buscando investir capital ou expandir negócios em terra estrangeira (HAESBAERT, 2006, p.246-247).
\end{abstract}

Quanto ao termo 'política migratória', pode ser compreendido, de acordo com Zolberg (2006, p.27), como "o conjunto de ações de governo para regular a entrada, a permanência e a saída de estrangeiros de território nacional, bem como as ações destinadas a regular a manutenção dos laços entre o Estado e os seus nacionais que residam no exterior”. Nessa perspectiva, a política migratória corresponde a uma ação de Estado na regulação de seu vínculo com os estrangeiros que se encontram em seu território, bem como com os seus nacionais que estejam sob a jurisdição de outro Estado.

Como argumenta Siciliano (2013, p. 9), a política migratória é um fenômeno social complexo, com enfoque também jurídico, uma vez que:

(...) determina as condições de outorga da cidadania a estrangeiros em seu território, assim como as condições de exercício da cidadania de seus nacionais que se encontrem sob a jurisdição de outros Estados. Dessa forma, sendo um fenômeno jurídico, são os textos normativos que definem uma política migratória (independentemente de sua denominação), estabelecendo quem são, e em quais condições, os estrangeiros que serão titulares de direitos. As políticas migratórias, portanto, variam significativamente de um Estado para outro, e mesmo ao longo da história de um país. Assim, políticas de emigração e imigração muitas vezes atingem matrizes complexas de diferentes normas e práticas.

Cabe salientar que a política migratória de cada país contém elementos e diretrizes sobre a imigração e a emigração, de modo que a ênfase pode ser dada a uma ou a outra conforme o contexto socio-histórico, a situação e as necessidades de cada país. Não obstante, Siciliano (2013, p.22) chama a atenção para o fato de que a questão migratória, muitas vezes, é observada "pela ótica do Estado-nação, em abordagens tipicamente realistas do sistema internacional", em que o indivíduo migrante não é tomado como agente ou como sujeito de diretos, mas como um elemento da equação de fluxos migratórios, que gera efeitos para o Estado emissor e para o receptor. 
Além dessas medidas usuais pertinentes a políticas migratórias, há outras medidas possíveis que, mesmo não sendo tipicamente associadas a tais políticas, podem ser inseridas nesse contexto quando se referirem ao ingresso, à permanência ou à saída de estrangeiros de território nacional. Como exemplos, podem ser mencionadas medidas que aumentem ou restrinjam o acesso aos serviços sociais pelos imigrantes, tributação diferenciada em relação aos migrantes, adoção de políticas sociais em relação aos migrantes, ou o grau de participação política permitida a eles (ZOLBERG, 2006).

Desse modo, a noção de política migratória, muitas vezes, permanece restrita às decisões governamentais que dizem respeito à entrada, à permanência e à saída de pessoas do território de um dado país, bem como aquelas destinadas a cuidar dos cidadãos nacionais emigrados. Embora se reconheça sua relevância, nem sempre se permite a participação direta de entes ou organizações não governamentais na formulação dessa política por questões de soberania e competência legal. Como observa Siciliano (2013), a influência desses elementos na formação da política migratória de determinado país depende, sobretudo, de condições específicas do país emissor ou do país receptor de migrantes.

Adicionalmente, a qualidade da mão-de-obra de um determinado país, a instrução de seu povo e o grau de desenvolvimento econômico são fatores determinantes no estabelecimento de uma política migratória, pois condicionam o debate sobre a maior aceitação de estrangeiros. E atitudes de preconceito, situação geopolítica do Estado e questões de política externa também são fatores de forte influência na determinação dessa política (SICILIANO, 2013).

Nesse sentido, os mecanismos por meio dos quais se opera uma política migratória são diversos, culminando em regras (mais abertas ou mais restritivas) que apontam o perfil de uma política migratória. A esse respeito, Siciliano se propõe a compilar:

(...) as diversas práticas analisadas, tendo em conta a perspectiva humanista, para definir o conjunto de ações que desenham a política migratória de um país. Ainda que sem a pretensão de estabelecer qualquer hierarquia, ou mesmo de estabelecer limites, pode-se dizer que uma política migratória, qualquer que seja ela, é definida por: (i) sistema de vistos adotado; (ii) existência de acordos regionais que facilitem a migração regional; (iii) medidas que visem a integrar o imigrante à sociedade; (iv) incentivos à reunião familiar; (v) medidas de controle de fronteiras; (vi) incentivos a trabalhadores estrangeiros; (vii) políticas subnacionais para gestão de contingente de imigrantes; (viii) sistema de detenção de imigrantes irregulares; (ix) políticas de seleção de imigrantes; (x) estabelecimento de quotas à imigração; (xi) política de acolhimento de refugiados/asilados; (xii) anistias; (xiii) outorga de direitos políticos a imigrantes; (xiv) aparelho estatal para o atendimento de imigrantes; (xv) medidas para cidadãos nacionais exercerem sua cidadania à partir do exterior; (xvi) política de capacitação de trabalhadores nacionais para atuarem no exterior; (xvii) política de retorno; e (xviii) incentivo ao envio de remessas (SICILIANO, 2013, p.25-26). 
O rol acima pode ilustrar a variedade de medidas e envolvidas e pode contribuir como uma matriz para análise de políticas migratórias, seja de país desenvolvido ou em desenvolvimento, predominantemente emissor ou receptor de imigrantes. Após apresentar conceitos formulados acerca de termos e aspectos relevantes no âmbito do fenômeno das migrações, são considerados a seguir alguns desenvolvimentos teóricos em torno dessa temática, bem como as dificuldades para se erigir uma teoria das migrações coesa o bastante para abarcar todos os seus enfoques multidisciplinares.

\section{2 - Abordagens teóricas sobre o fenômeno das migrações internacionais}

De acordo com Massey et al. (1993), a maioria dos países desenvolvidos do mundo se transformou em sociedades caracterizadas pela diversidade étnica, e aqueles que não atingiram esse estado estão se movendo nessa direção. Nesse contexto, a assunção da migração internacional como uma característica estrutural básica de quase todos os países pode atestar a intensidade e a coerência das forças subjacentes aos fluxos migratórios.

No entanto, a base teórica para a compreensão dessas forças permanece fraca, e a esse respeito Massey et al. (1993) argumentam que:

Os recentes acréscimos de imigração surpreenderam, assim, a muitos cidadãos,
gestores públicos e estudiosos, e quando se trata de migração internacional, o
pensamento popular continua atolado em conceitos, modelos e hipóteses do século
XIX. No momento, não existe uma teoria única e coerente da migração
internacional, apenas um conjunto fragmentado de teorias que se desenvolveram
em grande parte de forma isolada uma da outra, mas nem sempre segmentadas por
fronteiras disciplinares. Padrões e tendências de imigração atuais, no entanto,
sugerem que uma plena compreensão dos processos migratórios contemporâneos
não será alcançada baseando-se nas ferramentas de uma disciplina por si só, ou
concentrando-se em um único nível de análise. Ao contrário, sua natureza
complexa e multifacetada requer uma teoria sofisticada que incorpore uma
variedade de perspectivas, níveis e pressupostos (MASSEY et al., 1993, p.432).

Castles e Miller (2009) salientam que a pesquisa acerca da migração envolve necessariamente enfoques multidisciplinares, de modo que cada um tem sua relevância na compreensão do processo: sociologia, relações internacionais, ciência política, história, economia, geografia, demografia, psicologia, antropologia, direito. Os autores argumentam que os estudos sobre migração internacional se dividem em dois grupos bem delimitados de investigação social e científica: "primeiramente, pesquisas sobre determinantes, processos e 
padrões de migração; e em seguida, pesquisas sobre os meios pelos quais os migrantes se incorporam nas sociedades que os recebem” (CASTLES; MILLER, 2009, p.20).

Os desenvolvimentos teóricos acerca das migrações, sobretudo nas últimas décadas, vêm se dedicando à investigação de temas e questões específicos, tais como: etnicidade, xenofobia, gênero, identidade, comunidade e cidadania. De acordo com Castles e Miller (2009), há relevantes desenvolvimentos produzidos acerca dos fluxos migratórios agrupados em teorias, conhecidas como: teoria neoclássica; teoria do mercado de trabalho dual; teoria dos sistemas mundiais; teoria de redes de migração; teoria transnacional.

Massey et al. (1993) distinguem abordagens teóricas de migração internacional em duas categorias: abordagens teóricas que explicam o início da migração e abordagens teóricas que explicam a continuação da migração no tempo. Nessa perspectiva teórica, a teoria econômica neoclássica, a teoria do mercado de trabalho dual, a nova economia da migração laboral, e a teoria dos sistemas mundiais tentam explicar o início da migração. A teoria institucional e a teoria das redes migratórias, por sua vez, procuram explicar o curso dos fluxos migratórios internacionais ao longo do tempo, de modo que estas teorias tentam esclarecer, entre outras questões, por que os fluxos migratórios internacionais continuam a aumentar mesmo se o incentivo inicial para migrar vier a diminuir.

Desse modo, a caracterização das abordagens teóricas sobre o fenômeno das migrações, no âmbito deste estudo, considera a perspectiva desenvolvida por Massey et al. (1993, 2006). De acordo com esses autores, um exemplo de indicador que provoca fluxos de migração internacional entre dois países é a diferença salarial que os trabalhadores recebem em relação aos dois lados da fronteira, como forças de atração e repulsão. Assim, este início de migração pode instigar os fluxos internacionais de trabalho que persistem enquanto continuam as diferenças salariais, ou a desigualdade na distribuição de renda.

Uma das primeiras teorias modernas sobre migração, de acordo com Massey et al. (1993, p.434), é a teoria econômica neoclássica, desenvolvida a partir da década de 1980. Segundo esta teoria, as diferenças salariais entre as regiões são a principal razão para a migração laboral. Tais diferenças salariais seriam decorrentes de diferenças geográficas na procura e na oferta por trabalho, embora outros fatores também possam desempenhar papel importante, como, por exemplo, a produtividade do trabalho ou o grau de organização dos trabalhadores.

Numa perspectiva de ordem econômica, a teoria neoclássica é a principal herdeira dos modelos de atração e repulsão. Essa teoria possui duas formas de abordagem: a versão 
macroeconômica e a microeconômica. Na versão macroeconômica, os fluxos internacionais são influenciados pelos mecanismos do mercado de trabalho, ou seja, a migração internacional é causada pelas diferenças salariais e as condições de trabalho entre os países com baixos e altos salários (MASSEY et al., 1993).

Por sua vez, na abordagem microeconômica, a migração internacional é considerada uma forma de investimento em capital humano, onde os indivíduos são racionais e decidem migrar porque, ao calcularem os custos e os benefícios, criam a expectativa de que com a migração existe a possibilidade de obter na sociedade de destino um retorno líquido positivo, normalmente financeiro (MASSEY et al., 1993).

Apesar do modelo repulsão-atração e a teoria neoclássica serem importantes nos estudos da migração internacional, os seus principais pressupostos tornam-se questionáveis. Castles e Miller (2009) argumentam que tal teoria não constitui um quadro teórico capaz de classificar e ordenar os determinantes da migração no espaço. Outro ponto é que este modelo também se torna insuficiente à medida que não consegue explicar o porquê de um determinado grupo de indivíduos emigrarem para um determinado país em detrimento de outro (CASTLES E MILLER, 2009).

A abordagem das migrações de acordo com a teoria neoclássica também tem sido criticada por pressupor expectativas racionais, uma vez que o indivíduo possuiria conhecimentos exatos sobre o país de destino. De fato, Castles e Miller (2009) salientam que, na verdade, o migrante possui informações limitadas, as quais ainda podem ser contraditórias e não corresponderem à realidade encontrada no destino. Além disso, os indivíduos não podem decidir livremente sobre o destino da migração, pois "estão sujeitos a uma série de restrições, principalmente a falta de poder face aos empregadores e governos" (CASTLES; MILLER, 2009, p.23).

Outro pressuposto questionável dessa teoria, de acordo com Massey et al. (2006), é o argumento de que, com a migração, os salários nas sociedades de origem aumentariam e na sociedade de destino diminuiriam de forma que os movimentos migratórios deveriam continuar até os salários serem equiparados em ambas as sociedades. Nesse sentido:

\footnotetext{
A experiência histórica revela, contudo, que as diferenças salariais transnacionais raramente desaparecem. E, se isso acontecesse, seria através de uma variedade de mecanismos, entre os quais a migração não seria necessariamente a mais importante. Se o mundo funcionasse realmente como previsto pela teoria, muito mais pessoas moveriam e as migrações internacionais continuariam a crescer até produzir um salário de equilíbrio em todo o mundo. (...) A migração não terminaria com a igualdade de salários, mas com a realização de melhorias nas condições de vida nos países de origem" (MASSEY et al., 2006, p.34).
} 
Outra abordagem teórica é denominada como nova economia da migração (MASSEY et al., p.436), de acordo com a qual a decisão de se tornar um migrante de trabalho não pode ser explicada apenas no nível dos trabalhadores individuais, de modo que entidades sociais mais amplos têm de ser levados em conta também. Uma dessas entidades sociais a que se referem é a família, de modo que as famílias tendem a reduzir os custos envolvidos com a migração, e incentivam a migração de trabalhadores entre os agregados familiares para ampliar a renda no país de destino. Nessa perspectiva, os membros da família no exterior também incentivam as migrações por meio do envio de remessas de recursos, as quais têm um impacto positivo na economia dos países de origem e estimulam as famílias a enviar mais membros ao exterior.

Uma das principais contribuições dessa abordagem consiste em afirmar que a decisão de migrar não é concebida no âmbito individual, mas sim no coletivo. Ou seja, as decisões são concebidas tendo por base as unidades maiores de pessoas relacionadas que, além das famílias ou dos domicílios, incluem a comunidade "que agem coletivamente, não apenas para maximizar os rendimentos esperados, mas também para minimizar os riscos e os constrangimentos associados a uma variedade de mercados de trabalho" (MASSEY et al., 2006, p.36).

Para Castles e Miller (2009), embora a nova economia da migração tenha por base as decisões coletivas e apresente uma gama maior de fatores que influenciam a migração internacional, esta abordagem é semelhante à teoria neoclássica, na medida em que se concentra do lado da procura e nos motivos que levam os indivíduos a migrarem principalmente à procura de trabalho. Dessa forma, é relevante considerar a teoria do mercado de trabalho dual ou segmentado, como assim a denomina Castro (2011), a qual se refere à migração internacional não como resultado de decisões tomadas por indivíduos ou famílias, mas sim pela procura de trabalhadores estrangeiros para ocuparem os espaços de trabalho que os trabalhadores nativos geralmente não preenchem ou desprezam.

A teoria do mercado de trabalho dual argumenta que a migração internacional é causada, principalmente, por fatores de atração nos países receptores de migrantes desenvolvidos. Segundo esta teoria, os segmentos dos mercados de trabalho nesses países podem ser distinguidos como sendo de natureza primária ou secundária. O segmento primário é caracterizado por métodos de produção intensivos em capital e mão de obra predominantemente de alta qualificação, enquanto o segmento secundário é caracterizado 
por métodos de produção intensivos em trabalho, e por mão-de-obra predominantemente de baixa qualificação (MASSEY et al., 1993, p.440).

Nessa perspectiva, os trabalhadores nativos têm preferência pelo setor primário, pois os empregos são mais seguros, a remuneração é maior e existe a possibilidade de ascensão na hierarquia social. Ao contrário do que ocorre no setor primário, no setor secundário os salários são mais baixos, as condições de trabalho são mais instáveis e não há tanta perspectiva de mobilidade social. Assim, ocorre a procura permanente de trabalhadores com pouca ou nenhuma qualificação que aceitem tais condições (MASSEY et al., 1993, CASTLES E MILLER, 2009).

Nesse sentido, os empregadores possuem dificuldades em recrutar os trabalhadores nativos para as ocupações do setor secundário. Por conseguinte, desenvolvem práticas para a importação de trabalhadores estrangeiros, que não se importem com as condições impostas pelo segundo setor. As críticas dirigidas a esta teoria consideram que ao privilegiar a importância da procura por trabalhadores como causa da migração internacional, tal teoria acaba por menosprezar os fatores que se encontram do lado da oferta (CASTRO, 2011).

A última das abordagens teóricas referentes ao início das migrações é conhecida como a teoria dos sistemas mundiais (MASSEY et al., 1993, p.444), a qual considera a migração internacional a partir de uma perspectiva global. Esta abordagem enfatiza que a interação entre as sociedades é determinante para a mudança social que se produzem em seu meio, sobretudo no âmbito das migrações. Um exemplo de interação entre as sociedades é o comércio internacional, de modo que tais interações podem culminar em incentivos para a migração.

A teoria dos sistemas mundiais procura explicar as migrações como parte da dinâmica interna de um sistema único, o mundo econômico capitalista. Assim, a mesma economia capitalista que cria os migrantes nas regiões periféricas também os atrai para os países desenvolvidos. Nesta fase do processo migratório ocorre não somente a migração do trabalhador, mas também do capital, pois, as empresas de países capitalistas também estabelecem linhas de montagem nos países em desenvolvimento para tirarem proveito dos salários mais baixos (MASSEY et al., 1993).

A respeito da teoria dos sistemas mundiais, Sassen (2010) argumenta que a globalização econômica contribuiu para a definição de uma nova geografia da economia e da estrutura social, na qual o investimento estrangeiro é administrado indivíduos e grupos situados nas maiores cidades do planeta. Estas metrópoles, ao concentrarem as atividades 
financeiras e administrativas de serviços e de produção de alta tecnologia, acabam por atrair um grande quantitativo de migrantes, o que contribui para que o seu espaço urbano seja composto por uma multiplicidade de culturas e identidades diversificadas (SASSEN, 2010).

Nestas grandes cidades globais, a incorporação dos trabalhadores imigrantes, ocorre não somente no setor secundário, como afirma a teoria do mercado de trabalho segmentado, mas também no setor primário. Ocorre que as atividades concentradas nestas cidades, necessitam tanto de trabalhadores migrantes com baixas qualificações, como de trabalhadores migrantes altamente qualificados para a indústria de alta tecnologia em eletrotécnica, informática, telecomunicações, entre outras (MASSEY et al., 1993).

Não obstante, Castro (2011, p.26) salienta que:

(...) embora a teoria dos sistemas mundiais reconheça que as estruturas econômicas e políticas entre as nações contribuam para a definição dos sistemas migratórios, esta teoria não explica por que uma determinada pessoa que pertença a um conjunto de indivíduos com características semelhantes, pode tornar-se migrante e as outras não.

Feitas essas considerações a respeito das teorias que lidam com o início das migrações, são caracterizadas a seguir abordagens teóricas que se voltam para a continuidade dos movimentos migratórios no decorrer do tempo. A respeito das teorias que lidam com as migrações que persistem ao longo do tempo, faz-se referência à teoria institucional, à teoria das redes migratórias e à teoria transnacional.

De acordo com a teoria institucional (MASSEY et al., 1993 p.450), na medida em que a migração internacional passa a ocorrer em escala cada vez maior, pode tornar-se institucionalizada. Assim, um grande afluxo de migrantes internacionais induz à criação de nichos econômicos lucrativos para a operação de empreendedores e de instituições dedicados a promover o deslocamento de pessoas para aferir lucros, atuando em base legal (contratos de trabalho regulares) ou ilegal (atividades e documentos irregulares), podendo chegar à formação de um mercado negro no âmbito das migrações (ofertando meios de transporte clandestinos, documentos falsificados etc.).

Como argumentam os autores,

Na medida em que esse mercado subterrâneo cria condições que levam à exploração e à vitimização dos migrantes, organizações voluntárias em caráter humanitário também surgem nesses contextos para reforçar direitos e aprimorar o tratamento dos migrantes, tanto os legalmente instalados como os não documentados (MASSEY et al. 1993, p.450). 
Por sua vez, a respeito da teoria das redes migratórias, Massey et al. (1993, p.488) argumentam que, como resultado de grandes fluxos de migrantes internacionais, redes baseadas nas conexões entre os migrantes vão se formando, envolvendo vínculos interpessoais entre os que já migraram e os que tendem a migrar, tanto nas regiões de origem como de destino. Redes de migrantes podem, assim, ajudar potenciais migrantes da mesma origem, por exemplo, contribuindo para financiar a viagem, ajudando a encontrar um emprego ou alojamento adequado, ou fornecendo informações sobre as possibilidades de acesso a melhores condições de vida e de renda.

A respeito da teoria de redes migratórias, tal abordagem teórica (RAMELLA, 1995; GURAK; CACES, 1998) analisa a formação de redes sociais entre imigrantes e argumenta que essas redes podem diminuir os riscos da migração, o que incentiva a própria mobilização entre as fronteiras (Massey et al., 1993). Desse modo, tais redes seriam uma fonte de capital social e, por conseguinte, facilitariam a integração dos migrantes na sociedade de destino.

De acordo com Portes (1999), essas redes sociais podem ser compreendidas como:

Conjuntos de associações recorrentes entre grupos de pessoas ligadas por laços ocupacionais, familiares, culturais ou afetivos. As redes sociais são importantes na vida econômica, na medida em que são meios de aquisição de recursos escassos, como o capital e a informação, e porque impõem simultaneamente constrangimentos eficientes à prossecução ilimitada dos interesses pessoais (PORTES, 1999, p. 12-13).

De acordo com Ramella, (1995), o emprego da rede social nos estudos migratórios se generalizou rapidamente nos últimos anos, numa busca por novos caminhos por parte daqueles que criticaram e rechaçaram o enfoque estruturalista, que enfatizava os fatores de expulsão e ignorava as escolhas dos emigrados, as quais, quando mencionadas, eram julgadas como irrelevantes. Conforme a autora:

Para a metáfora da rede, passaram a ser considerados os emigrantes como atores racionais, que buscam objetivos e mobilizam para tanto os recursos à sua disposição, tais como recursos relacionais, ou seja, relações pessoais que servem para conseguir informação, escolher o destino, inserir-se no mercado de trabalho etc. (RAMELLA, 1995, p.11).

Já existia o conceito de cadeia migratória na bagagem de instrumentos metodológicos do estudo histórico das migrações, e daí se partiu para o desenvolvimento da ideia de uma rede social em torno dos migrantes. Nessa perspectiva, os pesquisadores que passaram a utilizar o enfoque da rede demonstraram a importância fundamental do estudo analítico para compreender os processos sociais através dos quais a informação passa e se 
difunde. São esses processos sociais (e não o encontro abstrato entre oferta e demanda) os que influem diretamente, de um lado, sobre a natureza e a composição da emigração, e do outro lado, a colocação dos emigrados no mercado de trabalho dos países receptores, ou seja, suas posições e suas recompensas (RAMELLA, 1995).

Gurak e Caces (1998) ressaltam a importância de redes baseadas em laços de parentesco, amizade e comunidade para a formação e o apoio à migração, conformando uma ideia de dinâmica da migração. Nesse contexto, as redes vinculam a comunidade emissora com a receptora e proporcionam uma estrutura coerente às populações de migrantes, de modo que operam e variam de acordo com contextos étnicos e políticos, e têm impacto sobre os migrantes e o movimento de migração.

Redes migratórias, assim, correspondem a construções complexas e variáveis, interligadas a outros fatores no âmbito dos sistemas migratórios. Os autores salientam a importância de se analisar o processo geral de formação de uma comunidade de migrantes, e argumentam que:

(...) as redes migratórias, ao interagir com a sociedade de destino e de origem, constituem a matéria prima para formação de comunidades étnicas na sociedade de destino. A persistência de vínculos entre descendentes e imigrantes radicados e as comunidades na sociedade de origem, mesmo em períodos de imigração reduzida, demonstra o papel que corresponde às comunidades étnicas já assentadas para manter o impulso com o que podem contribuir ao processo migratório (GURAK; CACES, 1998).

Como salienta Ramella (1995), são temas relevantes que o enfoque da rede permite reintroduzir e aprofundar: o caráter não indiferenciado dos fluxos migratórios; e as oportunidades às quais os emigrados têm acesso, especialmente através do acesso à informação. Desse modo, o que estrutura tais oportunidades são as redes de relações das quais os migrantes formam parte, e que eles constroem. Neste sentido, "tais oportunidades estão socialmente determinadas, pois não dependem de características pessoais, mas sim das relações entre os atores" (RAMELLA, 1995, p.15).

Por sua vez, Gurak e Caces (1998) argumentam que, embora as redes migratórias possam originar-se como redes de parentesco fortemente entrelaçadas, as necessidades subjacentes de diversos recursos (apoio com sistemas legais, melhor emprego, melhor moradia, opções de escolaridade, injeções financeiras etc.) devem predispor os migrantes a abrir suas redes e envolver elementos especializados além das bases em que se assentam e operam. Muitos dos novos elementos (pessoas, agências etc.) desempenham papéis regulares 
e importantes na comunidade imigrada, mas só estão debilmente ligados à maior parte dos membros da rede (GURAK; CACES, 1998).

Massey et al. (1993) salientam que o papel desempenhado pelas redes sociais contribui para que o processo migratório seja mais seguro e viável para os migrantes e as suas famílias. Desse modo, as redes aumentam a probabilidade de circulação internacional, porque além de garantirem segurança, contribuem para a redução dos custos e os riscos do processo migratório e podem ainda aumentar o retorno líquido esperado. A análise da composição da rede e de suas formas torna-se, assim, o ponto central, porque fornece uma chave explicativa para o fenômeno a partir desses elementos que abrem ou fecham o acesso às oportunidades.

Não obstante seu poder explicativo, há críticas à teoria da rede migratória que salientam suas dificuldades para esclarecer grandes fluxos migratórios internacionais, pois restrições em sua composição e em suas funções não explicariam por que os fluxos migratórios continuam a se expandir além desse contexto da rede migratória. Krissman (2005) salienta que tais restrições no conceito de rede migratória levam à distorção da análise acerca de como os fluxos migratórios se expandem e persistem ao longo do tempo e, dentre tais restrições, salienta a exclusão de uma série de atores envolvidos com a origem e a perpetuação dos fluxos migratórios, tais como: agenciadores de trabalho, empregadores, intermediários e assistentes.

Desse modo, a demanda por trabalhadores não seria um fator central na teoria da rede migratória. $\mathrm{O}$ autor alega que há nesse modelo assunções falsas, tais como: que as redes migratórias se originam e se resumem exclusivamente aos membros das mesmas cidades de origem; que a migração pode se perpetuar, continuando a ocorrer independentemente das ações dos atores fora das redes; e que o recrutamento laboral não sustentaria fluxos de migração em larga escala (KRISSMAN, 2005).

No decorrer da década de 1990, outra abordagem teórica foi introduzida nos estudos sobre as migrações internacionais. Esta teoria é conhecida como a teoria transnacional ou da comunidade transnacional. De acordo com Vertovec (1999, p.447), o transnacionalismo:

(...) descreve uma condição em que, apesar de grandes distâncias e da presença de fronteiras internacionais (e todas as leis, regulamentos e narrativas nacionais que elas representam), certos tipos de relacionamentos se intensificaram globalmente e agora tomam forma paradoxalmente em uma arena de atividade em escala planetária, ainda que comum, também virtual. 
De acordo com a perspectiva do transnacionalismo (PORTES, 1999; CAVALCANTI, 2005), salienta-se a necessidade de se compreender as novas migrações enquanto transmigrações, uma vez que o migrante não rompe suas relações culturais, sociais, econômicas ou familiares com seu país de origem e acaba interligando essas relações com a nova sociedade receptora. Dessa forma,

(...) o transnacionalismo emergiu da constatação que os imigrantes mantêm contatos entre o estrangeiro e o seu país de origem e fazem de ambos um território único de ação social. A partir de uma análise transnacional, os imigrantes já não estão desenraizados, ao contrário movem-se livremente de um lado para o outro através de fronteiras internacionais e/ou entre culturas e sistemas sociais diferentes. Estes migrantes influenciam a mudança nas comunidades ou locais de pertença, não só através das suas remessas econômicas, mas igualmente através de remessas sociais (GÓIS et al., 2006, p. 113).

Tal perspectiva teórica, além de fornecer explicações sobre a perpetuação dos movimentos migratórios, também contribui no sentido de evidenciar o desenvolvimento de diferentes modelos migratórios e de formas de interação entre os migrantes com as sociedades de acolhimento. De acordo com Portes (1999), uma das mudanças decorrentes da teoria transnacional consiste, assim, no fato dos imigrantes passarem a ser vistos como transmigrantes, que não são apátridas, mas sim indivíduos que mantêm atividades transnacionais e práticas transnacionais com dois países ou mais.

Para Castles e Miller (2009), o termo 'transmigrante' pode ser utilizado para identificar pessoas que participam de comunidades transnacionais baseadas na imigração. Não obstante, os autores ressaltam que nem todos os imigrantes podem ser caracterizados como tal, de modo que não seriam considerados transmigrantes aqueles migrantes que não mantêm ou não promovem vínculos entre as comunidades de origem e de destino. Por sua vez, Tedesco (2012, p.43) compreende o transmigrante como "alguém que imprime processos concomitantes, ou quase, entre dois territórios [o que] se manifesta em múltiplas atividades, situações, correlações, intercâmbios e vínculos".

A respeito do transnacionalismo, Portes, Guarnizo e Landolt (1999, p.219) delimitam seu conceito em termos de "ocupações e atividades que requerem contatos regulares e socialmente sustentados ao longo do tempo através de fronteiras nacionais, para sua implementação". Tal concepção, assim, envolve tanto os indivíduos como suas redes de relações sociais e suas comunidades, além de estruturas mais amplas e institucionalizadas, tais como os governos nacional e local.

Os autores salientam a importância, por razões metodológicas, em se definir apropriadamente a unidade de análise nessa perspectiva transnacional, a qual corresponde ao 
indivíduo e suas redes de apoio. Nesse sentido, outras unidades, tais como comunidades, empresas e grupos políticos, dentre outros, "também exercem influência em estágios subsequentes e mais complexos. Ainda assim, o indivíduo e suas redes correspondem ao ponto de partida mais viável para investigações sobre esse tópico" (PORTES; GUARNIZO; LANDOLT, 1999, p.220).

Cabe destacar, a respeito da abordagem transnacional, a investigação realizada por Cavalcanti e Parella (2013) com o objetivo de analisar o retorno dos emigrados a partir de uma perspectiva transnacional das migrações. Por meio dessa análise, os autores refletem sobre a complexidade inerente à prática do retorno ao país de origem em uma época em que as migrações estão fortemente marcadas por práticas sociais transnacionais. Nesse sentido, salientam que:

(...) compreender o retorno implica ir mais além das tradicionais lógicas interpretativas do retorno unicamente como o processo inverso da emigração. Assim, a ideia do retorno na atualidade se encontra em constante movimento, cada vez mais 'desterritorializado', e onde o transnacionalismo se converteu em uma realidade presente (CAVALCANTI; PARELLA, 2013, p.17).

Outro aspecto relevante desta abordagem, de acordo com Castles e Miller (2009), consiste na introdução do termo 'comunidades transnacionais', as quais que podem ser compreendidas como grupos baseados em dois ou mais países, envolvidos em atividades transmigrantes significativas, recorrentes e duradouras, que podem ser de natureza econômica, política, social ou cultural. Neste sentido, a melhoria nas tecnologias de transporte e comunicação, por um lado, possibilitaram maior interconexão entre o migrante e o seu país de origem, e por outro lado contribuíram "para o crescimento da mobilidade circular ou temporária, em que, as pessoas migram repetidamente entre dois ou mais lugares onde têm ligações econômicas, sociais ou culturais" (CASTLES; MILLER, 2009, p.30).

Enfim, Castles e Miller (2009) salientam que todas essas concepções teóricas em torno dos temas das migrações internacionais contribuem para a compreensão de que as abordagens teóricas que se propõem a explicar a origem e a continuidade dos fluxos migratórios não são necessariamente contraditórias entre si, mas antes complementares. Assim, ressaltam a relevância em se realizar investigações sob o enfoque interdisciplinar, o que possibilita a interpretação da mobilidade dos indivíduos sob diferentes aspectos e perspectivas, de modo que, por meio da interdisciplinaridade, é possível uma compreensão mais abrangente do complexo fenômeno migratório. 
Dutra (2013) também relaciona algumas abordagens teóricas no âmbito das migrações internacionais, tais como a teoria neoclássica, a teoria da nova economia das migrações a trabalho, a teoria do mercado de trabalho dual, a teoria dos sistemas mundiais, e a teoria das redes migratórias. Como observado por Dutra (2013, p.35), os fluxos de seres humanos são históricos, e podem ser vislumbrados como "consequência de contextos econômicos historicamente determinados".

Nesse sentido, é de suma relevância buscar compreender os primórdios dos movimentos migratórios para o Brasil, suas características e peculiaridades, como decorrência dos processos de formação nos quais se inserem, sobretudo em decorrência de sistemas de injeção de mão-de-obra ensejados pela necessidade de produção, bem como a atuação de instâncias governamentais de modo a fomentar, monitorar e/ou controlar os fluxos migratórios, conforme contextos sócio-históricos então vigentes.

\section{3 - Contexto histórico e sociopolítico das migrações internacionais para o Brasil}

Quanto ao contexto das migrações internacionais no Brasil, cabe salientar o argumento de Lopes (2009), em torno da ideia de que a própria história do Brasil pode ser contada a partir das migrações e dos deslocamentos de pessoas: a conquista pela Coroa Portuguesa e o influxo de europeus, os movimentos impostos aos indígenas forçados a se deslocar de suas terras, e a chegada dos africanos, capturados e transportados à força, que trouxe ao Brasil quase cinco milhões de africanos como escravos. Não obstante esses relevantes movimentos populacionais na história do Brasil Colônia, Lopes (2009) afirma que, usualmente, os fluxos migratórios no Brasil dizem respeito, especificamente, à política migratória de atração de estrangeiros por meio da imigração livre, estabelecida por primeira vez durante o Brasil Império.

Sobretudo a partir da segunda metade do século XIX, um novo agente social passou a desempenhar um papel cada vez mais relevante no Brasil: o imigrante estrangeiro. Estimativas (BASSANEZI et al., 2008) apontam que, dos imigrantes que ingressaram no Estado de São Paulo entre as últimas décadas do século XIX e as primeiras décadas do século XX, 36\% eram italianos, 20\% eram portugueses, 16\% eram espanhóis, $8 \%$ eram japoneses e o restante era composto por outras nacionalidades.

Silva (2005) afirma que o Brasil, como um país historicamente aberto à imigração estrangeira, posicionou-se em quarto lugar entre os países do continente em número de 
imigrantes recebidos, entre 1808 e 1955, com o ingresso de mais de quatro milhões de imigrantes. A vinda desses imigrantes esteve inserida no contexto das grandes migrações humanas no século XIX e na primeira metade do século $\mathrm{XX}$, as quais foram determinadas por um conjunto complexo de transformações originado na Europa e em outras regiões do mundo, provocando alterações de caráter sociodemográfico, decorrentes da expansão do capitalismo e de mudanças políticas em muitos países dos continentes europeu, asiático e americano. Tais transformações resultaram em excedentes populacionais em várias regiões, os quais foram direcionados às migrações, facilitadas pela impulsão das relações internacionais e pelo desenvolvimento das comunicações e do transporte.

Na perspectiva brasileira, a expansão do capitalismo em termos da produção e da exportação de produtos primários culminou não só na necessidade de mais mão-de-obra para alimentar a produção, como também sua transformação de escrava para livre. Além disso, como argumentam Bassanezi et al. (2008), outros fatores foram considerados nesse contexto, como a necessidade de povoamento diante de baixa densidade demográfica, a existência de espaços e mercados de trabalho acessíveis aos estrangeiros, aspectos ideológicos que privilegiavam o ingresso de contingentes de raça branca, preferencialmente europeia, bem como o forte estímulo do Estado brasileiro de modo a atrair migrantes.

A esse sistema de incentivos à imigração, impulsionado tanto pelas elites cafeeiras detentoras de poder político econômico quanto pelo aparato governamental do Estado brasileiro, Beiguelman (1981) se refere como imigrantismo, como um sistema que substitui, gradualmente, o escravismo como forma de produção privilegiada no Brasil Império.

A lavoura cafeeira, principalmente após 1871 - quadto decresce o interesse pelo investimento em escravos -, passou a apresentar a tendência de se organizar, gradualmente, com base no trabalho imigrante, e se voltava para as possibilidades propiciadas pelo surto imigratório de alguns países da Europa, como a Itália. Desse modo, grande parte desses imigrantes, como colonos, passavam a ser empregados nos cafezais em formação. A introdução de imigrantes em famílias, como salienta Beiguelman (1981, p. 32) permitia ao fazendeiro "obter um suprimento de trabalho suplementar de baixo custo, fornecido pelos demais membros do grupo familiar, enquanto que ao colono se tornava possível, através da cooperação da unidade familiar, um melhor aproveitamento das oportunidades de ganho".

Com o sistema de imigrantismo (BEIGUELMAN, 1981) em grande escala, subvencionado com recursos das administrações provincial e nacional, a lavoura cafeeira passava, cada vez mais, a interpretar a imigração subvencionada como alicerce de um 
abundante mercado de trabalho estrangeiro, que caberia aos cofres públicos proporcionar. Dessa forma, o imigrantismo oferecia a apropriação de mais ganhos à lavoura cafeeira do que a manutenção do escravismo. E é nesse sentido que, gradativamente, o desinteresse da lavoura cafeeira pelo suprimento em escravos torna evidente para a consciência nacional à época a perspectiva da viabilidade de um movimento voltado à abolição da escravatura.

Adicionalmente, ao interpretar os movimentos que culminam no imigrantismo, Beiguelman (1981, p.28), salienta alguns fatores relevantes: a característica peculiar do trabalho assalariado, com a possibilidade de expropriação de mais-valia aliada à conformação de uma capacidade tendencial de consumo que fortalece o mercado interno; as condições especiais em que a cafeicultura, particularmente, logrou promover a grande imigração subvencionada europeia; a conjuntura global em que se insere a absorção do trabalho imigrante, como uma opção adotada pelos setores mais influentes à época, do ponto de vista político e econômico.

De acordo com Bassanezi et al. (2008), com o passar dos anos, o sistema escravista dava sinais de esgotamento, de modo que a opção pela manutenção dos escravos se tornava cada vez mais difícil, mais cara e mais arriscada. Nesse contexto, ainda marcado pela predominância do escravismo, os fazendeiros passaram a tomar consciência de que tinham um problema de oferta de mão-de-obra para uma lavoura promissora, em plena expansão. Detentores de poder político e econômico e de grande influência junto ao Estado brasileiro, esses setores oligárquicos, vislumbrando para breve a abolição da escravatura, precisavam não apenas de um novo trabalhador, mas também de uma nova forma de trabalho, que atenuasse os custos e as turbulências associados à transição para um novo regime.

Assim, às vésperas da abolição e definido o colonato como a forma de remuneração dos trabalhadores estrangeiros, restava convencer o trabalhador europeu a emigrar para o Brasil. Bassanezi et al (2008) destacam que foram investidos esforços para a melhoria da imagem do país no exterior foram feitos, ao mesmo tempo em que agentes de divulgação foram contratados para percorrer aldeias recrutando imigrantes. Havia condições que favoreciam a emigração em alguns países europeus, especialmente a Portugal, Espanha e Itália, acumulando uma população rural excedente. Tais esforços foram mantidos e intensificados com o fim da Monarquia e com o advento da República.

Por sua vez, os fazendeiros de café tinham grande interesse em prover suas lavouras com uma oferta de trabalho abundante, que reduzisse os custos de mão-de-obra. Com a prosperidade do negócio do café, providenciaram mecanismos de financiamento tanto da 
produção como da comercialização do produto, bem como da importação de imigrantes com apoio do Estado brasileiro, através de uma política de subsídios que privilegiava a imigração em unidades familiares.

De acordo com Silva (2005, p.115), a elevação na entrada de imigrantes nesse período decorria da conjugação dos seguintes fatores: desenvolvimento da cafeicultura, proibição do tráfico negreiro, facilidades materiais oferecidas aos imigrantes pelos cafeicultores, abolição da escravatura e intranquilidade social nos países de onde emigravam as principais correntes de migrantes para o Brasil - italianos, alemães, espanhóis, síriolibaneses, poloneses, ucranianos e japoneses.

Como argumenta Lopes (2009), a forma como foi conduzido o processo de abolição da escravatura - que não pretendeu claramente a plena incorporação dos ex-escravos à sociedade - gerou a necessidade de atração de imigrantes para manter em funcionamento a economia agrícola. O afluxo de imigrantes entre 1880 e 1934 é estimado em cerca de 4,5 milhões de pessoas, tão contundente quanto o número total de ingressos de africanos escravizados durante todo o período em que o tráfico negreiro estava permitido.

Ao mesmo tempo em que a imigração foi concebida para a ideia de construir o país (ocupando terras para impedir que fossem invadidas) e incorporar mão-de-obra aos setores agrários em franca expansão, a chegada dos imigrantes e seu 'abrasileiramento' eram apontados como relevantes para a manutenção da unidade nacional. Nesse sentido, a imigração nesse período foi tratada de forma utilitarista, como salienta Lopes (2009), vinculada com interesses de povoamento, substituição de mão-de-obra e constituição da identidade nacional.

Como ressalta Beiguelman (1981), o fim da escravidão, longe de ser um processo de confirmação de direitos humanos, teve motivações predominantemente econômicas, tais como custos de manutenção da escravidão e pressões internacionais motivadas por interesses comerciais. Desse modo, após a abolição da escravatura em 1888, não se cogitou a doação de terras para escravos libertos, tampouco o pagamento de qualquer compensação. Além disso, como salienta Lopes (2009), os ex-escravos não tiveram as mesmas oportunidades concedidas aos imigrantes europeus, como se sua presença no país houvesse sido ignorada a partir do momento em que a escravidão foi abolida.

Desse modo, quando já se anunciava o fim da escravidão, a cafeicultura e o governo imperial já tratavam de atrair imigrantes europeus para as regiões Sul e Sudeste do país, com aportes financeiros custeados pelo governo. Além da política de incentivo do governo 
brasileiro, mais imigrantes foram atraídos para o Brasil em razão de instabilidades e precária situação social e econômica em vários países europeus. Lopes argumenta que essa política migratória:

(...) impôs uma contradição que até hoje influi na sociedade brasileira. Com efeito, a política desqualificava o nacional enquanto trabalhador para justificar a imigração estrangeira, e desqualificava o imigrante enquanto estrangeiro para justificar medidas discriminatórias que resultavam nos privilégios das elites (LOPES, 2009, p.277).

A principal intenção que motivava a introdução de imigrantes é usualmente reconhecida como a de substituir o trabalho escravo pelo assalariado, sobretudo para manter a expansão no cultivo do café. Não obstante, Lopes (2009, p. 277) identifica outras motivações relevantes nesse contexto: a pressão exercida por outras nações em torno do encerramento do tráfico negreiro e da abolição do sistema escravocrata no Brasil; a predisposição das elites em promover o "embranquecimento" da população brasileira; e o apoio conferido pelos cafeicultores à introdução do imigrante como um meio para resguardar o sistema produtivo que lhes conferia poder político e econômico.

Nesse sentido, Lopes (2009) menciona que uma verdadeira política de branqueamento da população foi estabelecida em 1890, no Governo Provisório da República. Adicionalmente, a autora destaca o Decreto nr. 528, de 28 de junho de 1890, com o pretexto de regularizar o serviço de imigração da nova república, bem como impulsionar a imigração e proteger os imigrantes, estabelecendo que:

\section{DA INTRODUÇÃO DE IMMIGRANTES:}

Art. $1^{\circ}$ É inteiramente livre a entrada, nos portos da República, dos indivíduos válidos e aptos para o trabalho, que não se acharem sujeitos à acção criminal do seu paiz, exceptuados os indígenas da Asia ou da Africa, que somente mediante autorização do Congresso Nacional poderão ser admitidos, de acordo com as condições que forem então estipuladas (LOPES, 2009, p.277).

Bassanezi et al. (2008) também reconhecem que uma ideologia valorativa da raça branca contribuiu para a opção pela imigração europeia, em detrimento dos escravos e seus descendentes, o que também determinou que os imigrantes adentrassem em um patamar da estrutura social superior ao da população de escravos libertos no Brasil. A própria imigração japonesa dependeu de autorização especial para ser implementada, e apenas após restringidas as possibilidades de se manter o influxos de imigrantes europeus, especialmente italianos.

Da perspectiva do imigrante, Bassanezi et al. (2008) argumentam que os subsídios e as esperanças de amealhar renda e de ter acesso à terra, veiculadas pela propaganda e pelos 
agentes recrutadores do Estado brasileiro, tornaram o destino brasileiro atraente a muitos migrantes, atraídos principalmente no âmbito do impulso econômico que dinamizava as regiões produtoras de café no Brasil.

A respeito da política migratória do Brasil Império, Cervo e Bueno (2009) argumentam que o Império não alcançou êxito em seu intento de promover a imigração livre em grande escala, a não ser entre 1880 e 1889, quando entraram no Brasil cerca de 450 mil europeus. Não obstante, Cervo e Bueno salientam que:

(...) a ação da diplomacia brasileira, incumbida de facilitar a coleta de imigrantes, esbarrava em sérias dificuldades, tais como: a) a imagem de uma sociedade escravocrata e de um país inóspito; b) o tipo de atividade a que se destinaria o imigrante; c) poderosas campanhas de difamação promovidas pelas companhias que operavam o grande movimento emigratório para os Estados Unidos e colônias europeias; d) investigações por agentes oficiais de governos europeus sobre as condições de vida de seus colonos no Brasil; e) proibições esporádicas da emigração para o Brasil por parte de governos europeus (CERVO; BUENO, 2009, p.84).

Cervo e Bueno (2009) argumentam que não se pode menosprezar os esforços do governo central e das províncias no sentido de superar dificuldades à imigração na época do Brasil Império, e de tornar o Brasil competitivo em termos de atração de imigrantes. De acordo com os autores, os frutos desses esforços "começaram a ser colhidos ao final do período e acabaram por transformar profundamente a sociedade brasileira" (CERVO; BUENO, 2009, p.85).

Em suma, a evolução do ingresso dos imigrantes no Brasil durante esse período de pouco mais de um século que vai desde a independência, em 1822, até o início dos anos 1930, de acordo com Silva (2005), possibilita a identificação de dois períodos distintos: um entre 1808 e 1850, e outro entr 1850 e 1930. A esse respeito, o autor argumenta que:

A primeira fase, situada entre a Abertura dos Portos do Brasil por Dom João em 1808, e a Lei Euzébio de Queirós, que proibiu o tráfico de escravos em 1850, caracterizou-se pela presença de um pequeno fluxo imigratório, explicado pela fácil obtenção de mão-de-obra escrava, pela instabilidade política do período regencial e pela longa Guerra dos Farrapos, que se estendeu de 1835 a 1845 . As principais correntes eram de açorianos, suíços, alemães e prussianos. A segunda fase abarca o período entre a Lei Eusébio de Queirós, de 1850, e a Revolução de 1930, identificando-se como a de maior entrada de imigrantes devido à conjugação dos seguintes fatores: desenvolvimento da cafeicultura, proibição do tráfico negreiro, facilidades materiais oferecidas aos imigrantes pelos cafeicultores, abolição da escravatura e intranquilidade social no Sul da Itália, em decorrência do processo de unificação do Estado italiano. As principais correntes eram de italianos, alemães, portugueses, espanhóis, sírio-libaneses, poloneses, ucranianos e japoneses (SILVA, 2005, p.115). 
Bassanezi et al. (2008), por sua vez, adotam perspectiva em que se divide o período após 1850 em duas fases distintas: de 1850 até 1902, e de 1902 até 1930. A seguir, são caracterizados cada um desses três períodos delimitados:

a) o primeiro se estende da independência até 1850, e foi caracterizado por experiências do governo imperial no sentido de recrutar imigrantes para as províncias do Sul do Brasil, principalmente alemães, sobretudo com o intuito de ocupar o território. Não obstante, esses influxos eram muito pequenos se comparados aos fluxos imigratórios da segunda metade do século XIX, e não chegaram a afetar o funcionamento do sistema escravista de produção;

b) o segundo se estende de 1850 até 1902, compreende o Segundo Reinado e o início da República. Esse período foi caracterizado pelo imigrantismo, ou seja, por um esforço sistemático dos setores produtivos e do aparato governamental do Estado brasileiro, inclusive agentes diplomáticos, em atrair contingentes de estrangeiros para trabalhar, sobretudo, nas lavouras de café, com subsídios à imigração e entrada maciça de imigrantes, principalmente italianos. Ao longo desse período, o sistema escravista foi abolido e a mão-de-obra nos cafezais foi substituída pelo trabalho assalariado dos imigrantes, em regime de colonato. Esse período findou em 1902, quando a Itália passou a dificultar a emigração subsidiada para o Brasil, ao mesmo tempo em que uma crise acometeu a cafeicultura ao final do século XIX;

c) o terceiro período se estende de 1902 até 1930, quando houve uma política de revalorização do café - por meio do Convênio de Taubaté, em 1906 - e, diante das dificuldades para a imigração italiana, houve aumento expressivo na imigração de portugueses e espanhóis, ao mesmo tempo em que teve início a imigração japonesa e a de países do Leste Europeu para o Brasil. Ao longo desse período, a cafeicultura enfrentou crises decorrentes de geadas e quebras de safra, bem como com a queda na demanda durante a Primeira Guerra Mundial, mas os esforços do Estado brasileiro mantinham a produção cafeeira como forte atrativo de imigrantes.

O fim desse terceiro período teve como referência uma série de acontecimentos que marcaram o fim do imigrantismo brasileiro: o término da política de subsídio do governo à imigração em 1927; a crise econômica de 1929 e a crise de superprodução do café, que alcançou seu auge em 1930; restrições impostas por diversos países europeus para a emigração de seus nacionais; e restrições impostas à imigração pelo governo de Vargas nos 
anos 1930, com a política de cotas e a campanha de nacionalização que pretendia a assimilação - à força, se necessário - da nacionalidade brasileira por parte dos imigrantes e de seus descendentes. Assim, a partir da década de 30, com a crise econômica mundial que acometeu pesadamente a atividade cafeeira, e com as restrições à imigração impostas pela Revolução de 1930 e de 1932, os fluxos migratórios para o Brasil se reduziram drasticamente em relação ao que se observava no período anterior, embora jamais tivessem cessado.

A partir da década de 50, o Brasil voltou a atrair algumas correntes migratórias de contingentes populacionais (principalmente portugueses, espanhóis, italianos e japoneses) que deixavam regiões afligidas pelas dificuldades de reconstrução decorrentes do período pós-guerra. No entanto, como argumenta Silva (2005), o golpe militar no decênio seguinte inaugurou uma fase de instabilidade interna que motivou, uma vez mais, a queda nos fluxos migratórios para o Brasil, a qual perdurou até a década de 70, quando o período de desenvolvimento conhecido como o 'milagre brasileiro' passou a atrair migrantes de países vizinhos do Brasil, (principalmente chilenos, paraguaios, argentinos e uruguaios), os quais enfrentavam dificuldades econômicas e/ou políticas causadas pelos regimes autoritários também vigentes entre eles.

A partir da década de 80, Silva (2005) salienta que a elevação do endividamento externo do Brasil, com graves consequências no plano econômico, culminou em desestímulo para a imigração no Brasil, e resultou numa tendência de emigração de brasileiros que se deslocavam para outros países em busca de melhores condições de vida e de trabalho. Passou a ser observado, ainda nesse período, um influxo migratório de contingentes populacionais (dentre os quais, chineses, coreanos, peruanos e bolivianos) que vinha ao Brasil clandestinamente e que permaneciam no território nacional de forma irregular, em número tão significativo que, ainda na década de 80 , o governo brasileiro promoveu anistia aos estrangeiros em situação irregular - uma medida que seria adotada novamente nas décadas seguintes.

Nesse contexto, Cervo (2008) salienta que a trajetória dos fluxos migratórios no Brasil, na segunda metade do século XX, evoluiu de um país de crescimento acelerado, com grande geração de emprego e renda, para outro de estagnação econômica e frustração social, de modo que:

(...) o marco da transição fixa-se em 1980, ano que simboliza a passagem de décadas de crescimento para décadas de estagnação. Não mais se observa aquele ímpeto para a frente, não mais aparecem estadistas de têmpera em condições de contagiar a sociedade. Daí a transição do movimento migratório. Assim como a 
imigração contribuiu no passado para configurar novo perfil da sociedade, a emigração reflete seu perfil de sociedade desigual e inerte no presente (...). Um Brasil pobre e desigual forçou a emigração de trabalhadores em busca de melhores condições de vida (CERVO, 2008, p.180).

A partir da metade da década de 90, com a estabilidade política e a recuperação econômica do Brasil, embora com indicadores sociais ainda atrás de regiões mais desenvolvidas ao redor do globo, observa-se que tanto o fluxo emigratório como o fluxo imigratório se intensificaram e se tornaram mais complexos. Como argumenta Cervo (2008, p.180), "durante a década de 1990, a globalização recessiva do Brasil manteve elevado o fluxo de emigrantes", e que a "emigração, sintoma de pobreza, mescla-se com o crime, sintoma de degenerescência social".

Lopes (2009, p.282) também reconhece a "conversão do Brasil em país de emigração", a partir da década de 1980 e intensificando-se na década de 1990, em decorrência de transformações que ocorreram no contexto laboral e econômico, e seus reflexos sobre os níveis de emprego e de renda. Nesse contexto, a autora destaca os impactos da instabilidade econômica que caracteriza o Brasil nos final dos anos 1980 e no início dos anos 1990, e comenta sobre os "resultados da estagnação econômica da década de 80: perdas salariais, deterioração dos serviços públicos, desemprego, aumento da desigualdade social e agravamento das condições de vida da população" (LOPES, 2009, p.286).

Não obstante, argumenta a autora que tais infortúnios econômicos não explicam, por si sós, a razão pela qual os brasileiros decidiram emigrar, de modo que:

Tendo o Brasil, nas décadas de 1980 e 1990, optado por liberalizar sua economia e
flexibilizar as condições de trabalho, está sujeito a todos os mecanismos de
sujeição típicos de um país que ocupa uma posição subordinada na (...) divisão
internacional do trabalho. Não é apenas o crescimento das taxas de desemprego e
das desigualdades sociais que impulsiona brasileiros a tentar a sorte no exterior. O
que move brasileiros para além das fronteiras nacionais é, principalmente, a
deterioração da qualidade dos empregos oferecidos, que não oferecem a muitos
deles a perspectiva de construir um patrimônio, e quanto menos de crescimento
profissional ou mesmo realização pessoal (LOPES, 2009, p.289).

Ao mesmo tempo em que se elevou a emigração de brasileiros nesse período entre as décadas de 1980 e 1990, a imigração reduziu sua intensidade, diante do contexto econômico adverso. Não obstante, com o advento dos anos 2000 e a recuperação econômica do Brasil, os movimentos migratórios de pessoas do e para o Brasil passaram a apresentar novas características: o influxo de contingentes de brasileiros retornados do exterior, muitas vezes trazendo suas famílias, o que foi ampliado diante da eclosão de crise financeira em 2008 que atingiu os principais países de destino dos emigrantes brasileiros; o acréscimo do número de 
solicitantes de refúgio e de refugiados no país, particularmente os provenientes de regiões de conflito, como sírios; e a chegada de contingentes de estrangeiros em busca de empregos e melhores condições de vida e de renda, alguns provenientes de países vizinhos, tais como paraguaios, bolivianos e peruanos, e outros que historicamente não se deslocavam ao território nacional em grande quantidade e passaram a fazê-lo, tais como senegaleses, congoleses, nigerianos, paquistaneses, bengalis e haitianos.

É oportuno ressaltar que muitos dos migrantes que pertencem a essa última categoria ingressaram no país de forma irregular e permaneceram aqui temporariamente como migrantes não documentados (ou seja, que ainda não detêm os documentos que possibilita sua estada regular no país), até que fosse possível a regularização - tanto pelas hipóteses de transformação de visto previstas em lei como pela anistia aos estrangeiros em situação irregular procedida pelo governo brasileiro no ano de 2009. Outra forma que os estrangeiros em situação irregular procuraram obter sua permissão no território nacional, ainda que provisoriamente, é por meio das solicitações de refúgio, ainda que o contexto sociopolítico em seus países de origem não ensejasse, em última análise, a concessão de refúgio.

Assim, é nesse contexto que se argumenta acerca da relevância da formulação e da implementação de política migratórias voltadas para fazer frente aos desafios que tais fluxos impõem ao contexto econômico, política e social, ao mesmo tempo que devem ser respeitadas garantias legalmente constituídas e cumpridos os acordos em caráter humanitário em favor dos que se encontram em situação de risco ou vulnerabilidade social, qualquer que seja sua origem.

Procedida a caracterização das abordagens teóricas sobre a migração internacional e consolidada a contextualização sócio-histórica do Brasil no âmbito dos fluxos migratórios desde o século XIX até movimentos mais recentes, as quais podem contribuir no sentido de fornecer alicerces à investigação, avança-se ao próximo capítulo no sentido de descrever as estratégias metodológicas seguidas para a consecução da pesquisa. Nesse sentido, a discussão acerca dos fluxos migratórios contemporâneos será retomada no quarto capítulo deste estudo, considerando a análise dos dados coletados no decorrer da pesquisa, no sentido de ampliar a caracterização desses movimentos migratórios para o Brasil no início do século XXI, sob perspectiva institucional, em termos de suas origens, desafios e tendências. 


\section{3 - Metodologia}

A escolha da estrutura metodológica para a pesquisa empírica configura-se como uma das principais preocupações do pesquisador, ao deparar-se com um problema de pesquisa a ser detalhadamente analisado e compreendido.

Daí a opção, portanto, pela pesquisa qualitativa por meio de uma investigação diagnóstica e situacional a fim de mapear a formulação e a implementação de políticas migratórias no Brasil, por meio da adoção de medidas e de processo decisório para fazer frente a tais fluxos, assim como a ação institucional relacionada a essas medidas, considerando dados e documentos obtidos junto a unidades organizacionais do MRE, do MTE e do MJ que atuam no âmbito das migrações. Considera-se, particularmente, as percepções de indivíduos que atuam como dirigentes em determinadas unidades desses ministérios, bem como a percepções de indivíduos que atuam em organizações não governamentais acerca da atuação dessas instâncias.

\section{1 - Tipo e técnicas de pesquisa}

O estudo pode ser classificado como descritivo e explicativo (MILLER, 1991), no sentido de descrever os principais aspectos dos fluxos migratórios de pessoas para o Brasil nos últimos anos e de caracterizar a ação institucional de órgãos públicos brasileiros que operam nesse âmbito, bem como de buscar explicar relações de causa e efeito ao analisar a atuação das instâncias governamentais no sentido de atender demandas desses contingentes de migrantes para o Brasil, tanto na perspectiva de dirigentes de unidades governamentais como de representantes de organizações não governamentais.

A pesquisa empírica envolveu uma avaliação diagnóstica e situacional a respeito da atuação do governo brasileiro no âmbito das migrações para o Brasil no início do século XXI, de modo a mapear tais fluxos migratórios e a ação institucional sob a forma de políticas em torno das migrações, em termos da caracterização das medidas adotadas e da avaliação de sua efetividade.

King, Keohane e Verba (1996, p.8) afirmam que uma pesquisa científica pode utilizar observações do mundo para proporcionar o entendimento acerca de fatos específicos, ainda que não diretamente observados. Investindo nessa possibilidade, esta pesquisa busca 
realizar inferências descritivas com o intuito de contribuir para uma melhor compreensão de políticas, princípios e estruturas para migrações no Brasil, os quais não se encontram formalmente descritos em um dispositivo legal ou jurídico coeso, mas podem ser inferidos a partir da atuação de instituições públicas brasileiras que atuam nesse âmbito.

Em suma, ao selecionar o escopo a ser investigado, o pesquisador deve ser cuidadoso em suas decisões de pesquisa, ao selecionar o tipo de organização e a natureza do fenômeno investigado. Nesse sentido, investiga-se a atuação de instituições brasileiras frente às demandas decorrentes dos movimentos migratórios contemporâneos, considerando a abordagem desenvolvida por Eisenhardt (1989) acerca de passos e atividades a ser seguidos em investigações empíricas, a qual foi levada em conta de modo a estruturar uma sequência de decisões metodológicas que culminaram na formulação do protocolo de pesquisa seguido por esta investigação, conforme o Quadro 1, a seguir.

\begin{tabular}{|c|c|}
\hline Passos & Atividades \\
\hline \multirow{2}{*}{ Iniciando a pesquisa } & Definição do problema de pesquisa \\
\hline & Construtos a priori \\
\hline \multirow{2}{*}{ Selecionando o objeto } & Contexto especificado \\
\hline & Seleção teórica, não-randômica \\
\hline \multirow{2}{*}{$\begin{array}{l}\text { Construindo instrumentos } \\
\text { e protocolos }\end{array}$} & Múltiplos métodos para coleta de dados \\
\hline & Dados qualitativos e quantitativos \\
\hline \multirow{2}{*}{ Indo a campo } & Sobreposição de coleta e análise de dados, com anotações de campo \\
\hline & Procedimentos de coleta de dados oportunos e flexíveis \\
\hline \multirow{2}{*}{ Analisando os dados } & Análise dentro do contexto \\
\hline & Busca por padrões cruzados \\
\hline \multirow{2}{*}{ Analisando hipóteses } & Tabulação iterativa de evidência para cada construto \\
\hline & Busca por fundamentação para relacionamentos entre categorias \\
\hline \multirow{2}{*}{ Envolvendo a literatura } & Comparação com a literatura similar \\
\hline & Comparação com a literatura conflitante, quando possível \\
\hline Alcançando conclusões & Saturação teórica, quando possível \\
\hline
\end{tabular}

Quadro 1. Passos para pesquisa empírica

Fonte: Eisenhardt (1989, p. 535)

Dessa forma, o primeiro passo envolveu a definição do problema de pesquisa e a seleção dos construtos a priori considerados nesta investigação, em torno do entendimento 
acerca de fluxos migratórios, imigração, emigração, migrante, rota migratória e política migratória, entre outros. Adicionalmente, foi especificado o contexto considerado, qual seja a atuação das instâncias governamentais que operam no âmbito das migrações no início do século XXI, e foram selecionados e contatados preliminarmente os participantes da pesquisa, tanto na esfera governamental como nas organizações não governamentais. Instrumentos de pesquisa (sob a forma de roteiros de entrevista) foram desenvolvidos para cada grupo de entrevistados, conforme constam nos Apêndices A e B.

Eisenhardt (1989) salienta que tais passos não seguem, necessariamente, sequência linear, de maneira que podem se sobrepor ou alternar entre si. Os passos e atividades a ser seguidos buscam subsidiar a realização de pesquisas empíricas, o que foi julgado como pertinente ao âmbito desta investigação. Dessa maneira, as estratégias e as decisões metodológicas traçadas nesta investigação buscam seguir, sempre que pertinente, os passos e as atividades sugeridos por Eisenhardt (1989) de modo a desenvolver protocolo de pesquisa para consecução deste estudo, como oportuno guia para orientar as iniciativas do pesquisador.

\section{2 - Caracterização de organizações e de participantes da pesquisa}

O estudo considera, particularmente, as percepções acerca da atuação frente aos fluxos migratórios de pessoas ao Brasil do ponto de vista de dirigentes de unidades relacionadas a tal área no âmbito de três ministérios, em unidades organizacionais que atuam diretamente com a formulação e a implementação de políticas governamentais para regulamentação, acompanhamento e controle acerca da migração de pessoas para o Brasil. Também foram incluídas na análise as perspectivas acerca da atuação das organizações governamentais brasileiras por parte de representantes de cinco organizações nãogovernamentais que lidam com o monitoramento, a atenção e o apoio aos migrantes, tais como caracterizadas a seguir.

Dentre tais órgãos e instâncias governamentais pesquisados no âmbito desta investigação, os quais têm atuação relevante no âmbito de fluxos migratórios do Brasil e para o Brasil, podem ser mencionados: o Ministério das Relações Exteriores (MRE), por meio de decisões e políticas desenvolvidas pelo Palácio do Itamaraty em termos da migração de pessoas e emanadas para suas unidades consulares ao redor do globo; o Ministério da Justiça (MJ), por meio de regulamentos e normas referentes ao controle e ao registro do 
ingresso e da permanência de estrangeiros no território nacional, bem como da adoção de restrições à entrada no país e de retiradas compulsórias; e o Ministério do Trabalho e Emprego (MTE), por meio da análise e da concessão de permissões de trabalho para estrangeiros e, particularmente, da atuação do Conselho Nacional de Imigração (CNIg) como órgão deliberativo e consultivo.

Nesse sentido, é oportuno realçar, brevemente, atribuições e responsabilidades que caracterizam a atuação dos órgãos governamentais na seara da imigração, a partir de informações institucionais coletadas em seus sítios na internet (http://www.justica.gov.br/seus-direitos/estrangeiros ; http://www.itamaraty.gov.br/o$\underline{\text { ministerio }} ;$ http://portal.mte.gov.br/cni ; http://portal.mte.gov.br/trab_estrang/trabalho-

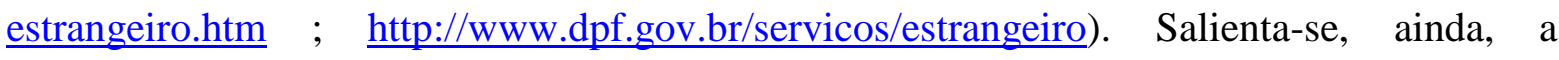
existência de interfaces em relação aos procedimentos realizados por cada instância.

a) Ministério da Justiça (MJ) - encontra-se na estrutura do MJ o Departamento de Estrangeiros - DEEST, vinculado à Secretaria Nacional de Justiça, no âmbito do qual são processados assuntos relacionados à nacionalidade, naturalização e regime jurídico dos estrangeiros. Desta forma, processos de permanência de estrangeiros no território nacional, de naturalização (processo pelo qual se adquire a cidadania brasileira) e de retiradas compulsórias (procedimentos que envolvem a retirada de estrangeiros do território nacional com o cumprimento de medidas administrativas ou judiciais), dentre outros, ordinariamente instruídos nas unidades descentralizadas do Departamento de Polícia Federal (DPF) são encaminhados ao MJ para decisão ministerial, direcionados ao DEEST. Também integra a estrutura do Ministério da Justiça o Comitê Nacional para Refugiados - CONARE, cuja atuação é relevante acerca da regulamentação e do processamento de solicitações de refúgio no Brasil.

b) Ministério de Trabalho e Emprego (MTE) - é responsável pela concessão da autorização de trabalhos aos estrangeiros, mantendo em sua estrutura: a Coordenação-Geral de Imigração (CGIg), responsável pela operacionalização dos processos de solicitação de vistos de trabalho com o apoio das unidades das Superintendências Regionais do Trabalho em todo o país; e o Conselho Nacional de Imigração (CNIg), sendo este um órgão colegiado, envolvendo representantes de diversos órgãos públicos, dos empregadores, das centrais sindicais e da sociedade civil, responsável, entre outras atribuições, por formular políticas de imigração e por opinar a respeito de propostas de alteração da legislação relativa à imigração. 
c) Ministério das Relações Exteriores (MRE) - mantém em sua estrutura o Departamento de Imigração e Assuntos Jurídicos (DIJ), a qual também é integrada por uma Divisão de Imigração (DIM). O DIJ é responsável pelo controle da emissão de vistos de entrada concedidos pelas repartições consulares brasileiras no exterior e pela legalização de documentos no Brasil, dentre outras atividades. Também merecem destaque os papéis exercidos pelas missões diplomáticas e pelas repartições consulares brasileiras, responsáveis pela concessão de vistos no exterior.

Lopes (2009, p.559) trata do contexto histórico da repartição de competências administrativas em matéria de migrações e remonta à década de 1960 como "o embrião da atual divisão de competências entre MRE, MTE e MJ no que diz respeito com o tratamento de estrangeiros". A autora salienta que essa repartição de competências coincide com o momento histórico em que a colonização mediante importação de mão-de-obra estrangeira deixou de ser prioridade para o país, ao mesmo tempo em que a importância quantitativa da imigração despencava e que cresciam as preocupações com a segurança nacional em relação ao contexto externo.

Nesse contexto histórico, foi promulgado o Decreto-Lei $\mathrm{n}^{\circ}$ 941, em 1969, o qual posicionava o MJ como responsável pela concessão de visto com base em relações de trabalho e estudos, estabelecia a competência exclusiva do MRE para a tramitação e a concessão de visto oficial e diplomático, mas silenciava sobre a atuação do MTE. Um pouco mais tarde, em 1980, surge a Lei $\mathrm{n}^{\circ}$ 6.815, que institui o Estatuto do Estrangeiro ainda vigente, o qual alterou a sistemática de competências dos órgãos governamentais e estabeleceu as possibilidades de ingresso, registro e permanência de estrangeiros no Brasil, bem como criou o Conselho Nacional de Imigração, dentre outras medidas.

De acordo com Lopes (2009, p.559):

\begin{abstract}
Atualmente, após a efetiva instalação do CNIg, são quatro os órgãos que exercem competências em matéria de imigração: Ministério das Relações Exteriores, Ministério do Trabalho, Ministério da Justiça (em parceria com a Polícia Federal) e Conselho Nacional de Imigração. Ao MRE compete a concessão dos vistos; ao MTE, a concessão de autorizações de trabalho (se e quando necessárias); ao MJ a tramitação de documentos relacionados com a permanência (em parceria com a Polícia Federal, que em verdade é subordinada ao MJ) e ao CNIg compete agir de maneira a atualizar a legislação e resolver suas lacunas ou omissões.
\end{abstract}

O Quadro 2, a seguir, descreve a repartição de competências no âmbito migratório entre essas instâncias governamentais, de acordo com Lopes (2009), caracterizando algumas de suas principais atribuições. 


\begin{tabular}{|c|c|}
\hline $\begin{array}{c}\text { Instância } \\
\text { governamental }\end{array}$ & Descrição e repartição de competências \\
\hline $\begin{array}{l}\text { Ministério das } \\
\text { Relações Exteriores }\end{array}$ & $\begin{array}{l}\text { O Ministério das Relações Exteriores exerce atribuições perante dois grupos bem } \\
\text { distintos: estrangeiros que mantêm laços com o Brasil; e brasileiros que mantêm } \\
\text { laços com o exterior. Quanto à primeira função, já se previa desde o início do } \\
\text { século XX a necessidade de concessão de visto aos que pretendiam entrar no país, } \\
\text { conforme a nacionalidade, a cargo das autoridades consulares subordinadas ao } \\
\text { MRE. Nesse contexto, o MRE dividiu tradicionalmente as competências } \\
\text { relacionadas à admissão de estrangeiros com o MJ acerca da concessão de vistos } \\
\text { temporários e permanentes, com exceção dos vistos oficiais e diplomáticos, cuja } \\
\text { atribuição para concessão era exclusiva para o MRE, inclusive em termos de } \\
\text { pedidos de prorrogação de estada e tramitação de documentos. Quanto à segunda } \\
\text { função, junto aos brasileiros no exterior, as atribuições do MRE dizem respeito a } \\
\text { atividades de assistência, representação e proteção aos brasileiros no exterior. No } \\
\text { exercício desta tarefa, podem ser realizados atos notariais e de registro civil, atos } \\
\text { referentes à nacionalidade, serviço militar e assuntos eleitorais, bem como } \\
\text { expedição de documentos. No tocante aos brasileiros que residem no exterior, as } \\
\text { repartiçõos consulares podem atuar de modo a fazer prevalecer o direito à } \\
\text { proteção consular em casos onde haja afronta aos direitos reconhecidos aos } \\
\text { estrangeiros. }\end{array}$ \\
\hline $\begin{array}{l}\text { Ministério da } \\
\text { Justiça }\end{array}$ & $\begin{array}{l}\text { Ao Ministério da Justiça são atribuídas funções concernentes à imigração por suas } \\
\text { competências voltadas às garantias de preservação da ordem e dos direitos, e } \\
\text { ainda por sua ascendência sobre a Polícia Federal. O Departamento de } \\
\text { Estrangeiros (DEEST) é órgão vinculado à Secretaria Nacional de Justiça que tem } \\
\text { por atribuições: processar, opinar e encaminhar os assuntos relacionados com } \\
\text { nacionalidade, naturalização e regime jurídico de estrangeiros; tratar de assuntos } \\
\text { relacionados com medidas compulsórias de expulsão, extradição e deportação; } \\
\text { instruir os processos relativos à transferência de presos para cumprimento de pena } \\
\text { no país de origem, com base em acordos dos quais o Brasil seja parte; instruir } \\
\text { processos de reconhecimento da condição de refugiado e de asilo político. É o } \\
\text { DEEST que decide sobre os pedidos de registro relacionados com a concessão de } \\
\text { vistos temporários e permanentes, bem como sobre a prorrogação e transformação } \\
\text { de vistos, quando couber. Para o exercício desta atividade, conta com o apoio da } \\
\text { Polícia Federal. }\end{array}$ \\
\hline $\begin{array}{l}\text { Departamento de } \\
\text { Polícia Federal }\end{array}$ & $\begin{array}{l}\text { Dentre as funções do Departamento de Polícia Federal, está a de exercer as } \\
\text { funções de polícia marítima, aeroportuária e de fronteiras. O DPF é órgão } \\
\text { subordinado ao MJ e atua em colaboração com o DEEST no que diz respeito ao } \\
\text { processamento e à tramitação de assuntos de estrangeiros, de modo que é a } \\
\text { Polícia Federal quem executa a interface com estrangeiros no Brasil, instruindo e } \\
\text { encaminhando os pedidos de permanência temporária ou definitiva, bem como } \\
\text { expedindo o registro e os documentos dos estrangeiros após a decisão favorável } \\
\text { do MJ. Para a emissão da cédula de identidade do estrangeiro, a Polícia Federal } \\
\text { lança mão de sistemas de cadastramento e registro de estrangeiros, com } \\
\text { informações acerca de sua identificação e sobre as condiçães de permanência do } \\
\text { estrangeiro no país. A Polícia Federal também exerce a função de polícia de } \\
\text { fronteiras, e muitas vezes é ali que se dá o primeiro contato do estrangeiro com o } \\
\text { país, conferindo a validade de documentos e vistos, e atribuindo prazos de estada. } \\
\text { Adicionalmente, a Polícia Federal faz cumprir as determinações do MJ a respeito } \\
\text { das medidas de retiradas compulsórias de estrangeiros do território nacional, tais } \\
\text { como deportação, extradição e expulsão. }\end{array}$ \\
\hline $\begin{array}{l}\text { Ministério do } \\
\text { Trabalho e } \\
\text { Emprego }\end{array}$ & $\begin{array}{l}\text { A atribuição do Ministério do Trabalho no que diz respeito a admissão de } \\
\text { migrantes assumiu relevância a partir do momento em que cessou a prioridade de } \\
\text { imigração para colonização, situação em que a imigração para o trabalho era } \\
\text { presumida e tida como necessária pelos gestores da política de imigração. Com o } \\
\text { Decreto-Lei } 941 \text {, em } 1969 \text {, o Ministério do Trabalho permanecia alijado do } \\
\text { processo, uma vez que a previsão de imigração dirigida poderia ser causa da } \\
\text { concessão de visto permanente pelo MJ, independente da concessão de qualquer }\end{array}$ \\
\hline
\end{tabular}




\begin{tabular}{|c|c|}
\hline & $\begin{array}{l}\text { visto de trabalho. Foi com o Estatuto do Estrangeiro de } 1980 \text { que o Ministério do } \\
\text { Trabalho recuperou seu papel em políticas de imigração, seja condicionando a } \\
\text { expedição de vistos à prévia autorização de trabalho dada por esse órgão, seja } \\
\text { vinculando o CNIg ao Ministério do Trabalho. Atualmente, é a Coordenação- } \\
\text { Geral de Imigração (CGIg), órgão diretamente vinculado ao Gabinete do } \\
\text { Ministro, a unidade administrativa do Ministério do Trabalho que tem } \\
\text { competência de decisão sobre as solicitações de autorizações de trabalho a } \\
\text { estrangeiros. Quanto à confecção da carteira de trabalho para estrangeiros, } \\
\text { compete às Superintendências Regionais do Trabalho, por meio de quaisquer de } \\
\text { suas representações, mediante a apresentação do extrato do contrato de trabalho } \\
\text { visado pela CGIg, publicado no Diário Oficial, além do passaporte com o } \\
\text { respectivo visto. }\end{array}$ \\
\hline $\begin{array}{l}\text { Conselho Nacional } \\
\text { de Imigração }\end{array}$ & $\begin{array}{l}\text { Órgão criado pelo Estatuto do Estrangeiro de } 1980 \text {, vinculado ao Ministério do } \\
\text { Trabalho, com atribuições para estabelecer e revisar exigências para a concessão } \\
\text { de vistos temporários e permanentes no Brasil. As competências originalmente } \\
\text { estabelecidas pela Lei } 6.815 / 80 \text { foram especificadas pelo Decreto Regulamentar } \\
86.715 / 81 \text {, e por sua vez foram atualizadas pelo Decreto } 840 / 93 \text {. Dentre as } \\
\text { competências do CNIg, de acordo com o art. } 1^{\circ} \text { do Decreto } 840 \text {, podem ser } \\
\text { mencionadas: formular a política de imigração; coordenar e orientar atividades de } \\
\text { imigração; efetuar levantamento periódico das necessidades de mão-de-obra } \\
\text { estrangeira qualificada, para admissão temporária ou permanente; promover ou } \\
\text { fornecer estudos de problemas relativos à imigração; estabelecer normas de } \\
\text { seleção dos migrantes, visando proporcionar mâo-de-obra especializada aos } \\
\text { vários setores da economia nacional e captar recursos para setores específicos; } \\
\text { dirimir dúvidas e solucionar casos omissos, no que diz respeito a imigrantes; } \\
\text { opinar sobre alteração da legislação relativa à imigração, quanto proposta por } \\
\text { qualquer órgão do Poder Executivo. No exercício de suas atribuições, o CNIg já } \\
\text { editou dezenas de resoluções administrativas que estabelecem critérios de } \\
\text { admissão de estrangeiros no país. A competência para solucionar casos omissos é } \\
\text { o instrumento que possibilitou a sistematização de situações importantes não } \\
\text { previstas na legislação de imigração, como o visto para tratamento de saúde e o } \\
\text { visto para companheiro em união estável. }\end{array}$ \\
\hline
\end{tabular}

Quadro 2. Repartição de competências entre instâncias governamentais

Fonte: LOPES (2009, p. 561-568).

Podem ser ressaltadas algumas recentes medidas que vêm sendo adotadas e/ou implementadas por essas instâncias governamentais de modo a implementar procedimentos relacionados a questões migratórias no Brasil, tais como: propostas de mudança à legislação referente à imigração, por iniciativa do CNIg, e emissão resoluções voltadas à regularização do ingresso e da permanência de migrantes (documentados e não documentados); criação de grupos de trabalho para realizar propostas voltadas ao aprimoramento de políticas migratórias, com diversos projetos em tramitação sobre o tema; alterações nos requisitos para concessão de autorização de trabalho e de vistos de trabalho de curta duração, bem como obtenção de visto temporário ao estrangeiro com vínculo empregatício no Brasil; emissão de resoluções normativas para reduzir prazos de concessão de vistos de trabalho; criação de comissões para realizar levantamento de informações junto às embaixadas brasileiras com vistas a otimizar o processo de concessão de vistos; criação de novos postos consulares ao redor do globo, ampliando a capacidade de atendimento; concessão de anistia 
aos estrangeiros que se encontravam em situação irregular no território nacional e que haviam ingressado até fevereiro de 2009; realização de audiências públicas em torno de temas como a proteção ao trabalhador migrante, com diversas ações propostas nessa área; assinatura de acordos com outros países da América do Sul no ensejo de facilitar a movimentação e a migração de pessoas entre os países da região.

Para a consecução da pesquisa, foram selecionados participantes inseridos em cada uma dessas organizações, com os quais foi estabelecido contato no sentido de receber informações acerca de documentos internos relevantes à questão migratória, bem como agendar e realizar entrevista conforme roteiro de perguntas semi-estruturadas. Com os participantes selecionados em organizações governamentais, foi aplicado o roteiro de entrevista que se encontra no Apêndice A. Por outro lado, o roteiro que se encontra no Apêndice B foi aplicado nas entrevistas junto aos participantes selecionados em organizações não governamentais.

Nas instâncias governamentais, foram cinco entrevistados: o diretor da Divisão de Imigração (DIM), no Ministério das Relações Exteriores; o diretor do Departamento de Estrangeiros (DEEST), no Ministério da Justiça; o coordenador-geral da Coordenação-Geral de Imigração (CGIg), no Ministério do Trabalho e Emprego (com participação do coordenador-geral substituto ao longo da entrevista); o presidente do Conselho Nacional de Imigração (CNIg); e o coordenador-geral da Coordenação-Geral de Polícia de Imigração (CGPI), no Departamento de Polícia Federal.

No tocante às organizações não governamentais, foram entrevistadas cinco pessoas, muitos dos quais atuando como observadores da questão migratória no Brasil, como dirigentes ou representantes das seguintes instituições: escritório regional da OIT no Brasil; escritório do ACNUR no Brasil; representação regional da OIM para a região sul-americana; sede do IMDH na cidade de Brasília; e sede da Missão Paz na cidade de São Paulo. Tais organizações são caracterizadas a seguir, conforme informações que constam em seus sítios na internet (http://www.oitbrasil.org.br ; http://www.acnur.org/t3/portugues ;

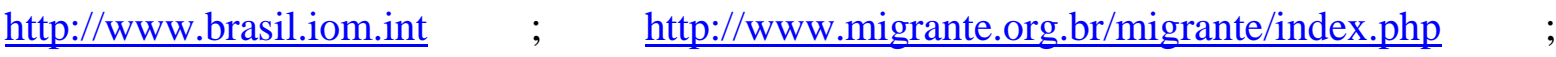
http://www.missaonspaz.org).

A Organização Internacional do Trabalho (OIT) é a agência das Nações Unidas que tem por missão promover oportunidades para que homens e mulheres possam ter acesso a um trabalho decente e produtivo, em condições de liberdade, equidade, segurança e dignidade. Tem a missão de promover oportunidades para que homens e mulheres possam 
ter um trabalho produtivo e de qualidade, em condições de liberdade, equidade, segurança e dignidade humanas, sendo considerado condição fundamental para a superação da pobreza, a redução das desigualdades sociais, a garantia da governabilidade democrática e o desenvolvimento sustentável. No Brasil, a OIT tem mantido representação desde a década de 1950, com programas e atividades que refletem os objetivos da Organização ao longo de sua história.

O Alto Comissariado das Nações Unidas para Refugiados (ACNUR) tem o mandato de dirigir e coordenar a ação internacional para proteger e ajudar as pessoas deslocadas em todo o mundo e encontrar soluções duradouras para elas. Iniciou seus trabalhos em 1950, e sua principal missão é assegurar os direitos e o bem-estar dos refugiados empenhando-se em garantir que qualquer pessoa possa exercer o direito de buscar e gozar de refúgio seguro em outro país e, caso assim deseje, regressar ao seu país de origem, prestando, assim, assistência aos refugiados no regresso ao seu país de origem ou na sua instalação em outro país. No Brasil, o ACNUR conta com um escritório em Brasília e uma unidade recém-inaugurada em São Paulo. A agência atua em cooperação com o Comitê Nacional para os Refugiados (CONARE), ligado ao Ministério da Justiça.

A OIM, criada em 1951, é uma das principais organizações intergovernamentais no âmbito das migrações, e trabalha em estreita colaboração com associados governamentais, intergovernamentais e não governamentais. Conta com mais de 150 Estados-membros e escritórios em mais de cem países, oferecendo serviços e assessoramento a governos e migrantes. A missão da OIM envolve promover uma gestão ordenada e humanizada da migração, bem como promover a cooperação internacional sobre questões migratórias, ajudar a encontrar soluções práticas aos problemas migratórios, e oferecer assistência humanitária aos migrantes em situação de vulnerabilidade.

Cabe salientar que a OIM ainda não conta com um escritório em funcionamento no Brasil, de modo que, embora já exista pedido formalizado pelo governo brasileiro para ingresso na OIM, ainda faltam ratificações por parte do Congresso e da Casa Civil para que o ingresso seja válido. Enquanto esse processo de ingresso ainda tramita, os representantes da OIM atuam no Brasil como observadores, e também por meio de parcerias com instâncias governamentais brasileiras no âmbito das migrações.

O Instituto Migrações e Direitos Humanos (IMDH), fundado em 1999, é uma entidade social sem fins lucrativos, filantrópica, cuja missão é promover o reconhecimento da cidadania plena de migrantes e refugiados, atuando na defesa de seus direitos, na 
assistência sócio-jurídica e humanitária, em sua integração social e inclusão em políticas públicas, com especial atenção às situações de maior vulnerabilidade. É vinculado à Congregação das Irmãs Scalabrinianas e à Rede Caritas, e atua em parceria com várias organizações da sociedade. Situado em Brasília, tem a missão de contribuir no atendimento integral a migrantes e a refugiados, incluídos migrantes internos, atuando na defesa de seus direitos, em favor de políticas públicas, articulação da rede institucional, assistência pastoral, sócio-jurídica e humanitária, para promover o respeito à sua dignidade e favorecer sua integração social e cidadão.

Por fim, a Missão Paz é uma entidade assistencial e filantrópica com sede na cidade de São Paulo, com atividades oferecidas por missionários scalabrinianos, cuja missão é acolher os migrantes, os imigrantes e os refugiados. Os serviços de acolhida ao migrante começaram em 1978. Os serviços de acolhida somaram-se a uma série de atividades que já eram desenvolvidas no âmbito da Missão Paz, visando a inserção dos migrantes, com destaque para a realização de cursos profissionalizantes. Conta em sua estrutura com a Casa do Migrante, um local onde essas pessoas podem ser instaladas e ter acesso a diversos serviços, assistências e informações. Atualmente, 90\% dos acolhidos são imigrantes e/ou solicitantes de refúgio.

Após a descrição das instituições em que foram selecionados os participantes da pesquisa, é oportuno caracterizar o perfil médio desses participantes. Todos os dez entrevistados (cinco em organizações governamentais e cinco em organizações não governamentais ) são do sexo masculino. Ao ser indagados acerca do tempo em que atuam predominantemente com questões migratórias, responderam, em média, que já atuam com esse tema há cerca de seis anos. Quanto ao tempo em que estão nos cargos em que atualmente ocupam, a média é de cerca de três anos. E a respeito de suas formações acadêmicas, a maioria é graduada em Direito e Administração, sendo que oito deles têm pósgraduação, três têm mestrado e um está atualmente cursando doutorado. Adicionalmente, cabe salientar que uma breve caracterização dos entrevistados e outras informações sobre as entrevistas encontram-se no Apêndice C, ao final deste estudo.

\section{3 - Procedimentos de coleta de dados}

Para a consecução do estudo, foi procedida coleta de dados concernentes a documentos internos de cada organização e a realização de entrevistas, bem como a 
momentos informais vivenciados pelo pesquisador inserido no âmbito de cada contexto institucional. Assim, denota-se o ensejo de empregar múltiplos meios para coleta de dados, conforme Eisenhardt (1989) como importante passo para pesquisa.

A pesquisa documental, considerando documentos internos obtidos junto às organizações investigadas de modo a subsidiar os propósitos da pesquisa, configura-se como uma "técnica valiosa de abordagem dos dados qualitativos", tal como mencionado por Lüdke e André (1986, p.3), ao complementar informações obtidas por meio de outras técnicas e, adicionalmente, ao revelar aspectos novos do tema investigado. A pesquisa documental, assim, corresponde a uma das principais técnicas para a consecução de pesquisa qualitativa, junto com a realização de entrevistas.

Desse modo, a coleta de dados, com vistas ao desenvolvimento de uma visão geral da organização, envolveu a obtenção de documentos internos relevantes, tais como estatísticas, relatórios, resoluções, regulamentos, normas, pesquisas, informes, atas de reuniões, bem como dados de sistemas informatizados e informações disponíveis nos sítios das organizações pesquisadas na internet. $\mathrm{O}$ acesso a muitos desses documentos somente foi efetuado após a realização das entrevistas com os participantes selecionados, de modo que no decorrer das entrevistas muitos desses documentos foram referidos ou caracterizados, e em alguns casos, inclusive, foi fornecida uma cópia ou foi possibilitado o acesso ao documento pelo próprio entrevistado ou por algum de seus colaboradores.

Quanto às entrevistas, foram realizadas com dez participantes selecionados nessas organizações. A entrevista é definida por Zanelli (2002, p.83) como "uma conversação com um propósito", de modo a "entender o que as pessoas apreendem ao perceberem o que acontece em seus mundos". A esse respeito, King (2004) argumenta que:

(...) o propósito de qualquer entrevista de pesquisa qualitativa é, portanto, conceber e compreender o tópico pesquisado a partir da perspectiva dos entrevistados, e entender como e por que eles chegaram a essa perspectiva em particular (KING, 2004, p. 11).

As entrevistas, segundo Lüdke e André (1986), podem ser classificadas em: estruturadas/padronizadas, quando têm de seguir estritamente um roteiro de perguntas feitas a todos os entrevistados; ou não-estruturadas/não-padronizadas, quando há mais liberdade de percurso na condução das perguntas ao longo da entrevista. Tendo em vista o escopo deste estudo, serão conduzidas entrevistas semi-estruturadas, que se caracterizam como um gênero misto, por seguir um roteiro de perguntas que não impede a formulação de novos 
questionamentos conforme a evolução da entrevista. Daí a opção pela entrevista semiestruturada - com perguntas abertas -, pois:

(...) um roteiro de entrevista serve como uma intenção de trajetória; mas aprofundar o relacionamento é prioritário, na medida em que somente assim podem-se obter os conteúdos procurados. (...) Isto proporciona abertura para que o entrevistado possa discorrer, nos limites de interesse da pesquisa, de modo como lhe parecer melhor. (...) Assim, dá-se liberdade ao entrevistado até que se ganhe confiança e não se percam elementos que podem ampliar a visão do pesquisador (ZANELLI, 2002, p. 84).

Nesse sentido, os roteiros de entrevistas foram desenvolvidos de modo a contemplar questões em torno dos principais temas investigados nessa pesquisa, e encontram-se inseridos nos Apêndices A (para participantes em organizações governamentais) e B (para participantes em organizações não-governamentais). O público-alvo das entrevistas correspondeu a dirigentes e representantes de unidades organizacionais (cinco governamentais e cinco não-governamentais) que atuam diretamente com fluxos migratórios para o Brasil, no âmbito das instituições investigadas, caracterizados conforme Apêndice C.

Todas as entrevistas foram realizadas em Brasília, entre junho e outubro de 2014, com exceção de uma, realizada por meio eletrônico, por meio do qual as perguntas foram enviadas e as respostas foram devolvidas. A duração média das entrevistas foi de aproximadamente quarenta minutos. Antes do início das entrevistas, foi assegurado a cada um dos entrevistados que os dados coletados seriam utilizados apenas para os fins da pesquisa e que sua identificação seria preservada, bem como a de suas opiniões e percepções a respeito do tema investigado. Desse modo, as verbalizações do que foi dito pelos entrevistados não são identificadas, e foram omitidas na análise quaisquer menções que pudessem permitir tal identificação, preservando, contudo, as percepções e as peculiaridades dos achados em termos de exprimir como é percebida a atuação das instâncias governamentais brasileiras no âmbito migratório.

Ao longo das entrevistas, foram apresentadas as questões do roteiro aos entrevistados, não necessariamente na sequência estabelecida, bem como foi solicitado que relatassem suas percepções a respeito de origens, causas, características, elementos mais destacados, tendências e desafios relacionados à atuação da unidade no âmbito de medidas relacionadas com a migração de pessoas, ao longo dos últimos anos.

Adicionalmente, foi requerida autorização do entrevistado para que a entrevista fosse gravada, de modo que as respostas obtidas pudessem posteriormente transcritas e analisadas. Anotações também foram realizadas pelo entrevistador no decorrer da entrevista, e forma 
consideradas conjuntamente para a análise dos dados. Apenas em um dos casos a autorização para a gravação não foi concedida, de modo que, apenas nesse caso, pôde-se contar apenas com as anotações efetuadas pelo entrevistador em termos de coleta de dados.

\title{
3.4 - Análise dos dados
}

Em seguida, foi realizada análise de conteúdo de todo o material obtido por meio da coleta de dados. A análise de conteúdo, de acordo com Lüdke e André (1986, p.41), corresponde a "um método de investigação do conteúdo simbólico das mensagens (...) abordadas de diferentes formas e sob inúmeros ângulos”. Franco (2003, p.10), por sua vez, argumenta que a análise de conteúdo, cada vez mais, tem sido "utilizada para produzir inferências acerca de dados verbais e/ou simbólicos, (...) obtidos a partir de perguntas e observações de interesse de um determinado pesquisador”.

A análise de conteúdo envolveu o exame dos dados obtidos por meio da pesquisa documental e das entrevistas, ou seja, opiniões e crenças verbalizadas pelos entrevistados, bem como anotações efetuadas pelo entrevistador ao longo das entrevistas. Após a organização dos dados e o estabelecimento de unidades de análise - a critério do pesquisador -, o que envolveu leituras sucessivas do material coletado, buscou-se a identificação de temas mais reiterados em termos do objeto de pesquisa. A partir da detecção desses temas mais frequentes, balizados pela literatura pertinente, foram desenvolvidas categorias conceituais de análise do fenômeno pesquisado, por meio do cruzamento dos dados obtidos em pesquisa documental e realização de entrevistas.

A respeito da construção de categorias, Zanelli (2002, p. 84) afirma que:

\begin{abstract}
Organizar e interpretar dados qualitativos é um processo de análise sistemática, em busca de uma descrição coerente. A organização em categorias facilita e permite atribuir significados, ou interpretar a realidade pesquisada. A análise (organizar e interpretar) é também um processo recorrente de aprendizagem para chegar à compreensão do fenômeno.
\end{abstract}

Por meio de exames sucessivos do material coletado e do arcabouço teórico em que se baseou a pesquisa, as categorias definidas inicialmente em relação à caracterização dos fluxos migratórios para o Brasil e da ação institucional correspondente foram refinadas e expandidas, submetidas a novos julgamentos quanto a sua abrangência e delimitação, possibilitando a compreensão das relações entre os desafios inerentes aos movimentos de 
migração de pessoas nos últimos anos, e o que se requer da atuação governamental em relação ao contex to considerado.

\section{5 - Limitações do estudo}

Em termos de limitações do estudo proposto, uma limitação refere-se aos procedimentos de coleta de dados em corte transversal, uma vez que a realização de uma coleta de dados longitudinal poderia permitir a mensuração, de forma mais adequada, da influência que o ambiente político e socioeconômico exerce ao longo do tempo sobre a evolução dos fluxos migratórios internacionais para o Brasil, em contínua mudança.

Adicionalmente, outra limitação diz respeito ao fato de não ter sido possível incluir na pesquisa, por conta de escassez de tempo e de recursos, outras instâncias governamentais brasileiras que atuam em âmbito migratório, tais como o Ministério do Desenvolvimento Social, o Ministério da Saúde e o Ministério da Educação. Embora tais instâncias não tenham um papel tão destacado como os participantes da pesquisa, sua inclusão poderia ter proporcionado a identificação de outros aspectos relevantes no tocante às respostas institucionais brasileiras aos fluxos migratórios em anos recentes. 


\section{4 - Resultados}

Os achados da pesquisa, com base nos resultados de pesquisa documental e das coletas de dados em entrevistas, foram organizados em tópicos de análise e são expostos conforme indicado a seguir. Inicialmente, são tecidos alguns comentários sobre o fenômeno das migrações contemporâneas no contexto do sistema internacional, enfocando de que modo o conjunto de instituições que compõem tal sistema vislumbra as questões migratórias em termos de preocupações e oportunidades, bem como posicionamentos, regimes e agendas desenvolvidos pela comunidade internacional em torno do tema. Em seguida, são efetuadas algumas considerações a respeito dos contingentes de imigrantes para o Brasil no início do século XXI, seus perfis, suas motivações e as demandas inerentes a esses fluxos migratórios, a partir dos dados coletados.

A atuação das instâncias do governo brasileiro no âmbito migratório é analisada em seguida, primeiro na perspectiva dos participantes que operam em organizações governamentais - em termos da análise de princípios norteadores, de desafios às ações governamentais nessa área, da articulação e da coordenação entre as instâncias e de tendências para o fenômeno migratórios nos próximos anos -, e por conseguinte conforme as percepções dos participantes que operam em organizações não governamentais - a respeito da avaliação das iniciativas governamentais em torno de políticas migratórias efetivas bem como do exame da ação coordenada entre tais instâncias.

Por fim, são examinadas e discutidas algumas medidas recentes do governo brasileiro em favor de novos entendimentos acerca da política migratória brasileira - tais como a adoção de novos posicionamentos institucionais acerca das migrações, a necessidade de revisão normativa sobre a questão migratória no Brasil, alterações no papel exercido por determinadas instâncias governamentais nesse contexto e o desenvolvimento de iniciativas inovadoras para ressaltar a relevância do tema para a conjuntura nacional, bem como algumas de suas principais tendências e sugestões para aprimoramento.

\section{1 - O fenômeno migratório em perspectiva internacional}

Políticas nacionais a respeito da migração internacional foram adotadas para lidar com diversas preocupações no contexto internacional, tais como: proteção de direitos 
humanos, segurança nacional, mercado laboral, desemprego, atração de mão-de-obra qualificada, envelhecimento populacional, integração social, xenofobia, concessão de asilos e refúgios, movimentos de pessoas em situação não documentada, tráfico de pessoas etc. Essas preocupações levaram, pela própria dinâmica que caracteriza o fenômeno, a um exame contínuo das políticas migratórias, bem como de potenciais vantagens e desvantagens da migração internacional no tocante aos países de origem, de destino e de trânsito.

De acordo com a experiência internacional, salientada por estudiosos dessa temática (CERVO, 2008; BATISTA, 2009; ASSAD, 2013), políticas migratórias são usualmente formuladas com a intenção de fazer frente à intensidade e à composição dos fluxos migratórios. Nesse sentido, o relatório de pesquisa econômica e social realizada pela ONU (2004) já ressaltava, há uma década, que o número de governos que adotaram medidas para restringir a migração internacional havia crescido significativamente, de modo que, em 2003, um terço dos países integrantes da ONU tinham políticas para conter ou reduzir a imigração, em comparação a apenas sete por cento dos países integrantes em 1976.

Adicionalmente, observa-se que há, atualmente, uma similaridade entre países desenvolvidos e em desenvolvimento a respeito de sua propensão em alcançar níveis mais baixos de imigração. Desse modo, em ambos os grupos, cerca de um terço dos países propunham políticas que buscavam reduzir a imigração (ONU, 2004). Não obstante, embora a maior parte dos países esteja gradualmente impondo controles mais rígidos sobre a imigração, aspectos como a reunião familiar e o atendimento ao mercado laboral se tornaram fatores de grande relevância para aceitar o ingresso de migrantes.

Nesse contexto, um número crescente de países desenvolvidos vem buscando aliviar a pressão por suprir postos vagos de trabalho em determinados setores por meio da promoção à imigração de trabalhadores de alta qualificação, conformando a busca por tais competências como critério de admissão de migrantes. Como resultado, os migrantes legalmente admitidos na maior parte dos países de destino no mundo desenvolvido têm correspondido a esse contingente de trabalhadores qualificados, salientando em grande medida as interligações entre as migrações internacionais e o mercado de trabalho global. Assim, o acesso a melhores oportunidades de trabalho - e, por conseguinte, a melhores condições de renda e de vida - consolida-se, cada vez mais, como uma das mais importantes forças motrizes no tocante às migrações, o que é reconhecido pela maioria das nações e dos organismos internacionais. 
Cabe salientar que, embora as políticas de admissão de migrantes tenham se tornado mais restritivas, de modo geral, os países de destino vêm conferindo maior atenção a políticas migratórias que enfocam a integração dos não nacionais que vivem em seu meio, seja pelo enfoque do multiculturalismo ou do assimilacionismo (CAVALCANTI; SIMÕES, 2013). Nos últimos anos, cresceu o número de países que informou à ONU programas de integração de migrantes implementados em seus territórios, sobretudo em países desenvolvidos, de modo que tais programas envolvem medidas como: oferecer oportunidades para aprimorar suas competências linguísticas ou vocacionais; adotar ações de combate à discriminação contra migrantes; revisão de instrumentos normativos de modo a facilitar a regularização e a naturalização; o reconhecimento da dupla nacionalidade; e, em alguns países, a concessão aos migrantes do direito a voto em eleições locais.

Uma importante tendência no sistema internacional tem sido o desenvolvimento de políticas migratórias em países de origem para ampliar os benefícios auferidos por meio da migração internacional e para reduzir os custos envolvidos (ONU, 2004). Tais políticas incluem medidas para facilitar as remessas de recursos feitas pelos migrantes, o apoio às redes que conectam os migrantes a seu país de origem, a facilitação da migração de retorno, o aprimoramento dos serviços consulares e, em alguns países, o direito dos emigrantes a votar em eleições nacionais no país de origem.

Desse modo, a complexidade do fenômeno da migração internacional e a ampliação de sua intensidade compeliram muitos governos nacionais a substituírem uma abordagem unilateral pelo desenvolvimento de uma cooperação internacional aprimorada, com o apoio de organismos internacionais, com vistas ao favorecimento da atuação institucional frente às migrações. Assim, os últimos anos têm testemunhado uma disposição renovada de governos nacionais ao investir esforços em nível bilateral, regional e internacional para encontrar novos meios de assegurar migrações que se processam ordenadamente (OIM, 2011).

Em relação a acordos bilaterais sobre a migração internacional, a gama de questões abrangidas por tais acordos foi ampliada, de modo a incluir questões tais como: migração laboral temporária, controle de migrantes em situação irregular, gestão de fronteiras, retorno de emigrados e gestão de remessas. O enfoque bilateral, embora eficaz para o avanço dos interesses migratórios entre dois governos nacionais, tem geralmente um foco geográfico bastante estreito e, portanto, contribui de forma limitada com vistas a iniciativas de atuação em âmbito regional ou internacional no tocante à mobilidade dos contingentes de migrantes. 
Em nível internacional, o sistema composto pelas Nações Unidas e outros organismos multilaterais vem promovendo uma série de atividades com o ensejo de abordar as principais questões migratórias. Para tanto, tal sistema tem investido esforços para a formulação, adoção e revisão de instrumentos jurídicos sobre a migração internacional, bem como para a promoção de fóruns voltados a incentivar o diálogo intergovernamental no tocante a essa temática. A ONU, por meio de diversas de suas agências, também tem procurado coletar, analisar e disseminar, sistematicamente, informações sobre os deslocamentos de contingentes populacionais ao redor do globo, tanto de migrantes laborais como de refugiados. $\mathrm{E}$ ainda há outros organismos intergovernamentais que têm tido papel cada vez mais ativo nestas áreas, particularmente contribuindo para a formulação de normas globais voltadas às migrações internacionais (ONU, 2004; OIM, 2011).

Uma vez que a migração internacional não aparenta ser suscetível de ter reduzida sua intensidade ou sua importância no futuro próximo, grande parte dos governos nacionais tem demonstrado cada vez mais interesse em aprimorar formas de cooperação internacional em torno do tema das migrações. Como salientado em informe das Nações Unidas (ONU, 2004), uma das principais tarefas, ao se lidar com os fluxos migratórios, envolve os esforços sistemáticos da comunidade internacional em torno da melhoria de condições e oportunidades para potenciais migrantes em seus países de origem, bem como da redução de consideráveis diferenças entre o bem-estar do indivíduo médio em um país desenvolvido em relação ao da maioria dos habitantes em países mais pobres.

O sistema das Nações Unidas também salienta a importância do desenvolvimento de uma agenda global que congregue a comunidade internacional em torno desse tema, com diretrizes para um esforço global de modo a lidar com as migrações internacionais de modo mais ordenado. Por outro lado, a migração internacional tem sido cada vez mais vislumbrada no sistema internacional como uma questão relacionada ao desenvolvimento (ONU, 2004).

Não obstante, as políticas migratórias ainda não refletem, em sua totalidade, esta perspectiva de desenvolvimento. É, portanto, necessário integrar a política migratória no bojo de políticas de desenvolvimento nacionais e internacionais, assegurando a compatibilidade e a coerência entre ambas, salientando que, tanto em países de origem como em países de destino, as políticas migratórias geralmente não são tratadas pelo mesmo ministério ou agência que lida com as políticas de desenvolvimento, de modo que mudanças nos arranjos institucionais em nível nacional tem se evidenciado como cada vez mais necessárias para superar tais lacunas. 
As políticas migratórias internacionais também precisam lidar apropriadamente com a situação de refugiados e solicitantes de refúgio, ou seja, os que se sentem compelidos a deixar seus países de origem por riscos a sua segurança e a de seus familiares. Nos últimos anos, quase três quartos dos refugiados do mundo viviam em países em desenvolvimento. Para reduzir o carga que grandes fluxos de refugiados podem impor a esses países, a comunidade internacional precisa aprimorar os mecanismos de partilha de responsabilidades perante os refugiados, como vem sendo defendido pelo ACNUR e outras agências.

Em suma, o sistema internacional reconhece que o tema das migrações ainda carece de um arcabouço de análise abrangente que aborde de modo coeso e sistemático o vasto leque de questões relacionadas a essa temática. Nesse sentido, as migrações, como fenômeno global envolvendo vários atores com diferentes perspectivas e interesses, requerem o desenvolvimento de uma abordagem global. Há, portanto, a necessidade de ampliar a cooperação na área dos deslocamentos de pessoas entre os países de origem e os países de destino, de modo a assegurar que os consideráveis desequilíbrios entre a oferta e a procura de trabalho em escala global não agravem nem perpetuem perturbações econômicas e sociais, seja no nível nacional, regional ou internacional. Não obstante, a cooperação multilateral em torno dos fluxos migratórios internacionais ainda tem sido insuficiente (ONU, 2004), de modo que tal lacuna na cooperação internacional enseja o desenvolvimento de novas estruturas e de um arcabouço de análise que considere tanto os interesses dos migrantes e como os das comunidades em que eles se inserem.

\section{2 - A imigração para o Brasil no início do século XXI}

Os recentes fluxos internacionais de pessoas para o Brasil, observados nos últimos anos, trouxeram novos elementos para a questão migratória no país, como a chegada em volume crescente dos naturais de países que não têm estreita relação com o Brasil - situação que não se conhecia desde a primeira metade do século XX. Se no início eram poucos, com o tempo o fluxo aumentou e redes foram se formando, com crescimento exponencial, chegando-se a 2014 com estimativas que ultrapassam vários milhares de novos migrantes.

Como argumenta Baeninger (2013), o século XXI anuncia o cenário da mobilidade, de modo que, apesar do ensejo de maior controle nas fronteiras, os fluxos internacionais de pessoas têm se intensificado em todo o mundo. Nesse sentido, os movimentos migratórios internacionais no Brasil, a partir dos anos 2000, reforçam a tendência de configuração de 
espaços das migrações, com a necessidade de novas perspectivas para as escalas transnacionais e os arranjos institucionais junto aos quais esses fluxos se processam, seus sentidos e repercussões dentro e fora das fronteiras nacionais. Nesse contexto,

\begin{abstract}
As evidências empíricas das migrações internacionais para e do país demonstram a complexidade e a heterogeneidade da imigração internacional neste século. Denotam os desafios teórico-metodológicos para explicações e análises das migrações de haitianos, chineses, coreanos, bolivianos, peruanos, paraguaios, imigrantes internacionais qualificados, imigrantes internacionais indocumentados, imigrantes refugiados, presentnes nos espaços migratórios construídos a partir de nexos transnacionais no Brasil imigrante do século 21 (BAENINGER, 2013, p.18).
\end{abstract}

De acordo com relatório sobre a inserção dos imigrantes no mercado de trabalho brasileiro, publicado recentemente pelo OBMigra (CAVALCANTI; OLIVEIRA; TONHATI, 2014), os trabalhadores imigrantes aumentaram, entre os anos 2011 e 2012, em $19 \%$ a sua presença no mercado de trabalho formal brasileiro, passando de $79.578 \mathrm{em} 2011$ a 94.688 em 2012. Por sua vez, entre os anos 2012 e 2013, o aumento foi de 26,8\%, passando de 94.688 para 120.056. No acumulado de 2011 a 2013, o número de imigrantes no mercado de trabalho formal cresceu $50,9 \%$, denotando forte incremento. As Unidades da Federação que mais empregaram imigrantes no mercado formal em 2013 correspondem às regiões Sudeste e Sul do Brasil, embora os empregadores nos estados do Sul foram os que registraram os maiores incrementos de trabalhadores imigrantes. Adicionalmente, o relatório do OBMigra destaca que os trabalhadores haitianos em 2013 passaram a ser a nacionalidade com mais presença no trabalho formal. Esses dados reforçam o empenho do meio acadêmico em consolidar dados e estimativas mais confiáveis em torno das migrações no Brasil.

A respeito dos dados coletados em pesquisa empírica em torno da imigração para o Brasil no início do século XXI, são consideradas a seguir as informações obtidas por meio de pesquisa documental e junto aos entrevistados a respeito dos movimentos de migração para o Brasil nesse período, tratando de examinar, dentre outros fatores: qual o perfil do migrante que participa desses fluxos; que países de origem mandaram migrantes ao Brasil com maior intensidade; quais suas principais motivações para migrar; que bases legais e normativas foram evocadas pela maioria desses contingentes migrantes no ensejo de permanecer no país; enfim, quais as percepções dos representantes das instituições brasileiras pesquisadas (governamentais e não governamentais) acerca da forma como se comportaram esses fluxos migratórios.

Tais informações foram consolidadas no Quadro 3, a seguir, considerando tanto os dados coletados em entrevistas como em pesquisa documental. 


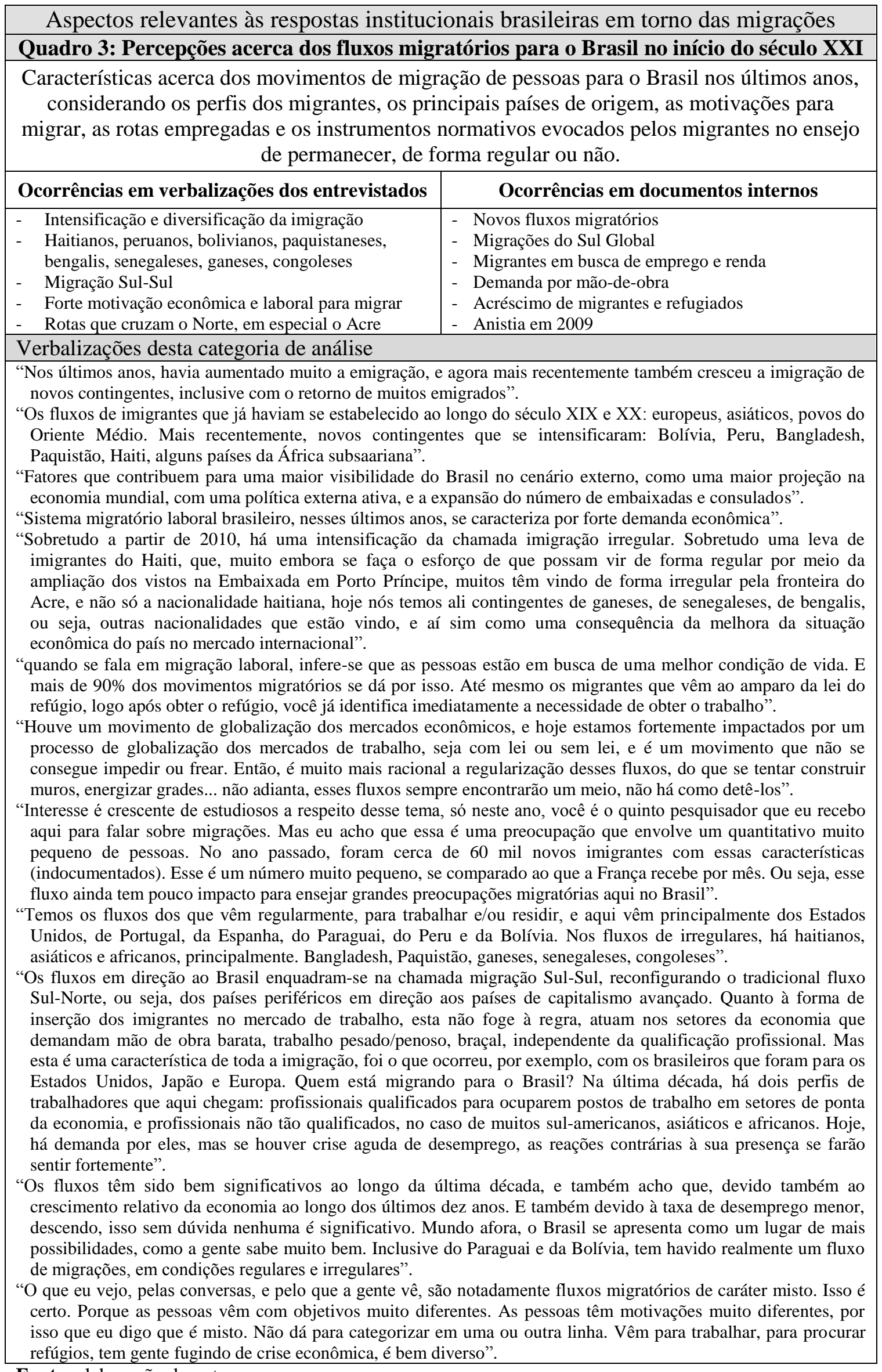

Fonte: elaboração do autor. 
Observa-se, assim, que os fluxos migratórios para o Brasil têm se intensificado e se diversificado muito, em termos de origens dos contingentes, em termos dos motivos da vinda ao Brasil, em termos das rotas empregadas, em termos dos recursos mobilizados para cruzar a fronteira. Tal entendimento é comum a todas as instâncias investigadas, com distinções em relação à intensidade dos fluxos e aos impactos que podem ser produzidos em médio e longo prazo. De acordo com os entrevistados e a pesquisa documental, os fluxos migratórios para o Brasil têm aumentado expressivamente nos últimos anos, sobretudo a partir do dinamismo da economia brasileira, o fato de que o Brasil ficou reconhecido como uma economia forte em nível nacional.

E esses fluxos migratórios são uma clara demonstração de que a economia do país teve forte período de crescimento, atraindo mão de obra e, por conseguinte, atraindo migrantes, porque esteve nesse período comparativamente melhor que outras economias. Como argumentou um dos entrevistados, "é quase uma lei tendencial das migrações em nível internacional, que as pessoas normalmente vão das áreas de menor desenvolvimento, para as áreas de maior desenvolvimento, de menor salário, para as áreas de maior salário, e das áreas que têm maior grau de tranquilidade, com situação mais estável, saem de áreas onde a situação está mais complexa, mais complicada; é uma lei tendencial, que ocorre dentro de cada país". Então, pode-se concluir que o dinamismo econômico experimentado pelo Brasil nos últimos anos, ampliando oportunidades de emprego e renda, foi um dos principais motivadores para o incremento e a diversidade nos fluxos migratórios para o país.

Não obstante, tal incremento não é tão elevado como se poderia supor, pois estatísticas mencionadas pelos entrevistados indicam que o quantitativo de estrangeiros que migram para o Brasil tem se mantido equilibrado, com a diferença de que, desde 2010, particularmente, há uma procura pelo país de um acréscimo considerável de migrantes em situação irregular, provenientes de países que antes não vinham com tanta intensidade, como bengalis, ganeses, senegaleses, congoleses e paquistaneses, configurando claramente a intensidade de migrações provenientes de diversos países do Sul global. É um aspecto novo para o Brasil, em termos da formulação e da implementação de políticas capazes de regular esses fluxos e de recepcionar esses contingentes migrantes, muitos dos quais com aspectos culturais e linguísticos bastante distintos em relação aos nacionais.

Pois correspondem a fluxos bem diferenciados em relação aos que foram registrados historicamente no Brasil, com a vinda de portugueses, italianos, alemães e japoneses, a partir 
de uma política de migração incentivada. Como afirma um dos entrevistados, é "diferente desse fluxo que nós estamos vivenciando, o Brasil nunca viveu essa situação... pois no passado, o Brasil estava, de certa maneira, mais preparado para receber aqueles contingentes, por toda uma estrutura que se havia montado".

Trata-se, nesses últimos dez anos, de uma mudança crucial nos fluxos migratórios para o Brasil. Até 2004, o maior fluxo era de emigração, com brasileiros que iam para o exterior em busca de trabalho, e menor fluxo de imigrantes que vinham para o Brasil. Embora as bases de dados ainda não possibilitem o fornecimento de estimativas mais confiáveis a respeito do número de emigrantes e imigrantes para o Brasil - em decorrência da dinâmica e da complexidade das migrações bem como de dificuldades em mensurá-la -, um dos entrevistados mencionou que "o Itamaraty estimou em mais de três milhões o numero de brasileiros que viviam no exterior, e naquela época o DPF indicava menos de 900 mil estrangeiros que viviam no Brasil. São números que tem que flexibilizar um pouco, porque não tem uma fonte muito firme para esses dados, mas são os números com que, naquela época, a gente aceitava trabalhar". Até então, tais fluxos de imigração se tratavam, basicamente, de fluxos regionais com os países que fazem fronteira com o Brasil, e poucos fluxos provenientes de outros continentes.

A partir de 2008, com a eclosão de crise financeira global, bem como o incremento da projeção do Brasil no cenário internacional, o país que passou a ter maior visibilidade externa. Com a manutenção de certo grau de crescimento conômico em modelo fundado na geração de empregos, o Brasil passou a se deparar com a situação de que, diante dos efeitos da crise financeira, não só os brasileiros deixaram de partir para o exterior, como muitos passaram a retornar ao Brasil, e passaram a existir fluxos significativos no processo de imigração, não só em termos de quantidade, como também em diversidade de países de origem dos migrantes. Como argumenta um dos entrevistados, "passamos a ter a vinda de pessoas de outras regiões que não tinham a tradição de vir aqui, e passamos a ter fluxos migratórios maiores, digamos assim".

Embora não se possa afirmar que o Brasil esteja experimentando fluxo migratório que aporta grande contingente de pessoas - pois, como salientaram dois entrevistados, " $o$ Brasil continua sendo um país de baixa imigração" e "o número de imigrantes no Brasil ainda é muito pequeno, se comparado ao total da população, ou à quantidade de imigrantes recebidos em outros países" -, tratam-se de fluxos que proporcionaram ao longo do tempo um incremento de imigrantes para o Brasil, e uma considerável diversificação de suas 
origens (haitianos, bengalis, paquistaneses, sírios, senegaleses, congoleses e ganenses, dentro outros), das rotas empregadas (em grande parte, por fronteira terrestre, cruzando pontos de fronteira em localidades no Norte do país) e das motivações para migrar (busca por melhores condições de emprego e renda, zonas de conflito ou calamidades naturais nos países de origem, fuga de situações de desemprego, instabilidade, risco ou vulnerabilidade social).

Grande parte dos migrantes ingressa no Brasil de forma regular, com a classificação de turista ou temporário por até noventa dias, e por não sair do território nacional após esse período, passa a permanecer no território nacional de forma irregular. Em 2009, o governo brasileiro adotou medidas no sentido de conferir anistia aos estrangeiros que se encontravam em situação irregular até fevereiro daquele ano, de modo que puderam regularizar sua situação no país. Desde então, os que se encontram no Brasil em situação irregular clamam por uma nova anistia, ou buscam na legislação brasileira outros meios pautados em instrumentos normativos para buscar a regularização de sua permanência no Brasil, ainda que de forma temporária ou provisória. É o que vem acontecendo, em grande medida, em torno das solicitações de refúgio no país.

A esse respeito, como argumenta um dos entrevistados, "nem todos os migrantes são refugiados, mas todos os refugiados e todos os solicitantes de refugio são migrantes". Dentro da corrente migratória em geral, refugiados são pessoas que, por razões de fundado temor de perseguição, tiveram que cruzar uma fronteira internacional por causa de motivos de raça, etnia, nacionalidade, opinião política e religião. Como argumenta o entrevistado, "então, sim, respondendo à pergunta, nos últimos anos, o número de pessoas que têm chegado ao país tem aumentado expressivamente. No ano 2010, chegaram aqui ao país 560 pessoas como solicitantes de refúgio. No ano 2011, esse número chegou a mais de 1.100. No ano de 2012, chegou a 2008. No ano 2013, chegou a 5.700. E neste ano, já estamos chegando a 4.000, então, estamos pensando que até o final do ano o número será ainda maior do que foi no ano passado".

Então, claramente o número de pessoas que veio ao país como solicitantes de refugio tem aumentado expressivamente, com muita intensidade, mas muitos dentre eles não se enquadrariam como refugiados conforme o entendimento em torno desse conceito. Não obstante, "evocam o instituto do refúgio como único meio possível para conseguir permanecer no Brasil, enquanto tramita o pedido de refúgio, pois o estatuto do estrangeiro não lhe dá outras opções, de modo que a lista de solicitantes de refúgio apenas aumenta, 
ainda que não se trate claramente da situação de refugiado". Dessa maneira, denota-se que o número de solicitantes de refúgio no Brasil contém expressivo contingente de migrantes que apelam ao refúgio como forma de buscar estabelecer-se no país. Essa é mais uma questão que deve ser levada em consideração pelas instâncias que operam nesse âmbito, impondo desafios para sua atuação efetiva.

\section{3 - Percepções dos dirigentes de instâncias governamentais brasileiras}

Neste tópico, são consideradas as percepções dos entrevistados acerca de aspectos referentes aos movimentos migratórios para o Brasil no início do século XXI, no âmbito de instâncias que lidam diretamente com a temática das migrações, quais sejam: a Divisão de Imigração, no MRE; o Departamento de Estrangeiros, no MJ; a Coordenação-Geral de Polícia de Imigração, no DPF/MJ; a Coordenação-Geral de Imigração, no MTE; e a Presidência do CNIg/MTE. Como salientado no capítulo da metodologia, foi firmado o compromisso perante os entrevistados de que nenhuma de suas verbalizações seria nominada, de modo a preservar suas identidades e a enfocar nos entendimentos acerca das questões propostas em perspectiva conjuntural, com o propósito de evidenciar aspectos em que haja convergências ou divergências em torno desses temas.

Nesse sentido, é pertinente ressaltar que, sempre que houvesse na verbalização o emprego de algum termo que pudesse contextualmente identificar de que organização o entrevistado faria parte, optou-se por omitir de sua fala o trecho que permitisse tal identificação. Assim, convencionou-se substituir tal termo pela expressão "denominação da organização omitida", sempre que julgado oportuno. Adicionalmente, salienta-se que não há qualquer tipo de ordenamento ou sequencia pré-definida para a listagem das verbalizações conforme a instância investigada, ou no tocante ao cruzamento de ocorrências entre dados coletados com as entrevistas e os documentos, de modo que tais elementos foram propositalmente 'embaralhados' nos quadros a seguir, de modo a assegurar que os entrevistados não seriam identificados por meio da verbalização de suas percepções.

A seguir, são considerados os resultados obtidos no que se refere a quatro categorias de análise, conforme os quadros 4 a 7, quais sejam: princípios norteadores das ações institucionais em torno das migrações; desafios ao desenvolvimento de ações institucionais frente às migrações; articulação e coordenação das ações entre instâncias governamentais; e tendências em relação aos fluxos migratórios para o Brasil nos próximos anos. 
Percepções dos dirigentes de instâncias governamentais quanto às migrações Quadro 4: Princípios norteadores das ações institucionais em torno das migrações

Valores, atributos ou paradigmas expressos, implícita ou explicitamente, em termos de entendimentos, costumes ou regras fundamentais que orientam a formulação de políticas migratórias, sugerem rumos a ser seguidos pelas instâncias governamentais e delimitam diretrizes de atuação institucional nesse âmbito.

\begin{tabular}{|l|l|}
\hline Ocorrências em verbalizações dos entrevistados & \multicolumn{1}{|c}{ Ocorrências em documentos internos } \\
\hline - Direitos humanos e direito ao trabalho & - Direitos humanos \\
- Soberania & - Trabalho digno \\
- Segurança nacional e proteção das fronteiras & - Soberania e segurança \\
- Proteção da mão de obra nacional & - Noção de cidadania mundial \\
- Facilitação à circulação de pessoas & - Salvaguarda do mercado de trabalho nacional \\
- Reciprocidade & - Integração regional e global \\
- Apoio humanitário & - Solidariedade \\
\hline
\end{tabular}

Verbalizações desta categoria de análise

"O eixo das migrações é o trabalho, e não a catástrofe".

"Implantamos para a área migratória princípios gerais, voltados à noção de direitos humanos, com respeito e preservação de direitos, independente de quão específica seja a questão migratória. Mas também acreditamos no exercício do controle dos fluxos de pessoas, como uma questão de soberania e de segurança nacional".

"Em termos de princípio, entendemos que a questão migratória é de direitos humanos. Seja enfoque humanitário ou laboral, a gente sempre procura perceber que, por trás do processo, há pessoas, há vidas, que precisam de uma decisão célere, mais justa possível, que vai impactar em sua situação".

"Também como princípio, temos a questão econômica, um trabalhador e seus dependentes, então também temos um enfoque pragmático, técnico, de privilegiar a proteção da mão-de-obra nacional. Então, na hora de decidir entre uma questão econômica e o interesse do trabalhador nacional, temos que sopesar se existe mão-de-obra nacional disponível para tal demanda econômica, então, não se justifica trazer um trabalhador estrangeiro se essa vaga pode ser suprida por um trabalhador nacional".

"Também conta como princípio a formalização do vínculo empregatício, aqui no [denominação da organização omitida], porque com o visto concedido, o estrangeiro vai poder ingressar no mercado de trabalho formal, até mesmo como microempreendedor individual, conforme o caso".

"O Acordo sobre residência temporária para estrangeiros provenientes do Mercosul e de países associados, aqui também tem um princípio interessante, que é a ideia de facilitar a livre circulação de pessoas entre os países do Mercosul, como uma meta a ser atingida. Ele pode exercer qualquer atividade, pode ser empreendedor, ou não fazer nada disso, como no caso de alguém já aposentado".

"Em relação a princípios, eu acho... primeiro, assim, a migração deveria ser encarada como um direito. Porque ninguém pode ser obrigado, nem pode ser exigido de alguém que passe privações onde vive. Isso não é exigível de ninguém. As pessoas têm direito a buscar uma vida melhor, isso é um direito universal".

"Sobre os princípios que norteiam as ações em torno das migrações, posso mencionar os direitos humanos, por parte do MTE, a reciprocidade, por parte do MRE, e também a segurança do país, por parte do MJ. É um tripé, e os princípios acabam compartilhados entre os três em seus campos de atuação, também por uma questão de soberania. Mas é o MJ a principal instância que pode fazer o contraponto entre os direitos humanos e a segurança nacional, porque é de sua natureza lidar com essas questões por competência institucional".

"Sobre a segurança nacional, também é importante nesse contexto. Nem todos os estrangeiros que ingressam no Brasil vêm com intenções de agir dentro da lei, então, no sentido de coibir o crime organizado internacional, o tráfico, inclusive o de pessoas, e o terrorismo, é importante que se mantenha a segurança nacional e a proteção das fronteiras como princípios válidos, pois se acontece algo desse tipo, é sobre esses princípios que podemos nos valer para que o ingresso e a permanência dessas pessoas no território nacional possam ser contidos".

"o que se tem feito, diante da legislação deficiente, sob o viés da segurança nacional, uma lei feita para a ditadura, onde o estrangeiro é considerado um agente potencialmente nocivo para o status quo, então, a gente procurou alargar as possibilidades migratórias, e estabelecer novos canais. Quebrar esse paradigma de que o trabalhador estrangeiro vem aqui para tirar o trabalho de brasileiros. Tudo isso evoluiu muito, e nós conseguimos de fato ter várias novas possibilidades de vinda".

"Hoje, nós sabemos que, além de estar substituindo o predomínio de uma certa escala de valores, nós não abrimos mão da discussão sobre segurança, não abrimos mão da discussão sobre desenvolvimento, mas temos outra orientação, de que o antagonismo contra a pessoa migrante, contra o fluxo migratório no Brasil, simplesmente não realiza objetivos de segurança nacional, não realiza objetivos de proteção à economia nacional. Que são muitas vezes mais bem realizados se forem harmonizados com os demais princípios da ordem constitucional brasileira".

"Então, lidar com essa realidade, e perceber que, além de realizar, existem muitos outros objetivos estratégicos brasileiros que não... a interpretação dada à segurança e ao mercado nacional nos anos 80 , que hoje precisa ser outra... e existem muitos outros objetivos estratégicos que precisam ser atingidos com uma política mais igualitária em termos de migrações. Então, isso tudo está envolvido".

Fonte: elaboração do autor. 
Acerca dos princípios que norteiam a formulação e a implementação de políticas migratórias no Brasil, os dados coletados com as entrevistas apontaram os seguintes: a migração como um direito; o direito ao trabalho digno; o respeito aos direitos humanos; a prestação de apoio de caráter humanitário; o exercício da soberania; a proteção das fronteiras nacionais; a reciprocidade no trato com outros países; a segurança nacional; a proteção da mão-de-obra nacional. Vários desses princípios encontram ressonância nos dados coletados em pesquisa documental, de modo que se encontram expressamente formalizados em documentos em caráter oficial.

O que se observa em relação a convergências e divergências em torno dos princípios é a existência de certa dicotomia que estaria relacionada, por um lado, ao pleno exercício dos direitos por parte dos indivíduos e, pelo outro, ao legítimo exercício das medidas de soberania e controle por parte do Estado. A maior parte dos entrevistados denotou que não há incompatibilidade entre esses princípios, mas sim a necessidade de ser conjugados. Nesse sentido, o respeito aos direitos humanos e a preservação das garantias fundamentais assumem papel essencial no sentido de conferir a tônica desse movimento pendular entre os direitos individuais e a segurança estatal.

A esse respeito, argumenta um dos entrevistados: "eu não quero dizer com isso que qualquer pessoa tenha o direito de entrar em qualquer lugar do mundo, mas considerar as migrações um direito significa não criminalizar o migrante. Ele não é um criminoso. Ele violou uma regra do Estado, certo, mas isso não é um crime. Porque ele está lutando por um direito humano que é fundamental. Então, assim, ninguém migra para violar a ordem jurídica de um país. As pessoas migram em busca de oportunidades".

A importância das migrações para a história do país também é salientada, tanto pela ótica do desenvolvimento socioeconômico como pela própria formação da identidade nacional. Nesse sentido, argumenta um entrevistado: “se a gente pega a história das migrações no Brasil, ela é uma história positiva. Ou seja, os migrantes que aqui vieram ajudaram a construir o país em que vivemos, de modo que foram agentes no processo de desenvolvimento. Sobretudo no Brasil, até pelo histórico do país. Agora se fala muito sobre o valor de o país ser miscigenado, ser multicultural, então, isso é um valor, eu acho. Realmente é um valor". Esse aspecto do valor histórico das migrações também é mencionado por outros entrevistados, salientando que a importância de construir um entendimento nacional sobre as migrações e evitar a 'importação' de perspectivas externas que fomentam a xenofobia e a aversão aos migrantes. 


\section{Percepções de dirigentes de organizações governamentais quanto às migrações} Quadro 5: Desafios ao desenvolvimento de ações institucionais frente às migrações

Problemas enfrentados concreta ou potencialmente pelas instâncias governamentais que operam no âmbito das migrações, os quais podem afetar ou impedir sua atuação de modo mais efetivo, sob a forma de pontos frágeis, dificuldades e obstáculos que carecem de soluções ou aprimoramentos com vistas à formulação e à implementação de ações e políticas migratórias.

\begin{tabular}{|l|l|}
\hline Ocorrências em verbalizações dos entrevistados & \multicolumn{1}{|c}{ Ocorrências em documentos internos } \\
\hline - Lei $n^{\circ}$ 6.815/80 antiga, desatualizada e anacrônica & - Estatuto do Estrangeiro precisa ser atualizado \\
- Falta de conscientização sobre o tema no Legislativo & - Tramitação lenta do projeto $\mathrm{n}^{\circ}$ 5.655 no Congresso \\
- Falta de políticas para o acolhimento ao migrante & - Necessidade de informatização de processos \\
- Morosidade no processamento de solicitações & - Necessidade de fortalecer consulados e fronteiras \\
- Instâncias públicas surpreendidas e sobrecarregadas & - Entraves burocráticos precisam ser reduzidos \\
\hline Verbalizações desta categoria de análise
\end{tabular}

"Hoje, não, hoje esses fluxos, de certa maneira, surpreenderam os órgãos envolvidos na área de migração, que não tinham histórico anterior de como acolher esses imigrantes que chegaram e que vêm chegando, e que de certa maneira nos confronta com a situação de recebermos uma mão-de-obra que não foi... de certa maneira, não foi estimulada, ou não foi prevista".

"temos hoje uma lei defasada, a 6.815, de 1980. É uma lei que vê o migrante ainda sob o aspecto da segurança nacional, e não sobre o enfoque dos direitos humanos. Então, está muito defasado ao longo do tempo. Você tem uma lei anacrônica, e você tem os enfoques atuais de direitos humanos que adquirem um status cada vez mais relevante perante toda e qualquer estrutura, seja produtiva, laboral ou econômica".

"É um processo gradual que implica muitas mudanças de mentalidade, tendo que dar mais atenção na área consular, que é internamente uma área que tende a ser menos valorizada, pois é mais braçal, operacional, mas que para muitos estrangeiros representa o primeiro contato com o Brasil. E esse contato é uma vitrine".

"No entanto, os partidos políticos no legislativo ainda não atentaram para a relevância da temática migratória, e ainda precisam de uma conscientização em torno da questão migratória. Já está consolidada a percepção, para muitos, de que o tema é urgente e relevante, mas ainda não são a maioria”.

"Hoje o [denominação da organização omitida] tem a meta, desde dezembro de 2013 , de alcançar $100 \%$ de seus processos sobre esse tema digitalizados, circulando entre as instâncias em meio digital. Já estamos quase alcançando essa meta. Hoje, acontece a seguinte situação: os trabalhadores estrangeiros que vêm ao Brasil por conta de um contrato de trabalho de dois anos, e que vão requerer uma permanência maior, eles não entram aqui. Esse pedido vai ser feito perante o [denominação da organização omitida], um pedido não de visto de temporário, mas de transformação em permanente, mas hoje o [denominação da organização omitida] ainda está trabalhando apenas com o processo físico, em papel. Então, de lá para cá, existe um estrangulamento, que é uma morosidade excessiva, porque tudo está tramitando em meio de papel".

"A lei é antiga, e o Estatuto do Estrangeiro realmente tem discurso com alguns elementos xenófobos".

“A Lei 6.815/80 está, sim, defasada nos dias atuais, e cabe uma atualização. Nós também reconhecemos essa necessidade. Mas que não se diga que é uma lei com problemas, pois foi uma lei muito bem elaborada. Em sua época, participaram dela renomados juristas, e ela foi pautada em aspectos muito coerentes. A questão é sua atualização, porque os tempos são outros, e trazem novas questões ainda não contempladas".

"Há que se prezar pelo acolhimento dos estrangeiros que vêm para o Brasil, e dos migrantes em particular".

"esse cenário traz desafios enormes. A gente trabalhava com uma imigração pequena, seletiva, até porque eram trabalhadores que vinham com uma qualificação muito mais baixa, aonde você tinha empresas que demandavam, então eles chegavam com a vida já resolvida. E você passa a ter outro cenário em que o Brasil passa a receber pessoas de uma maneira maior, sem as estruturas de recepção estabelecidas".

"Essa mudança de cenário, há muito tempo, já demandava uma mudança legislativa. O Brasil está atrasadíssimo na mudança de seu marco normativo".

"A Lei da Imigração, ainda é uma lei de critérios de admissão e de direitos, mas ela não chega nessa parte de acolhimento, e nem pode, porque para fazer isso seria necessária uma lei complementar. Seria outra dinâmica".

"E também falta toda uma regulação que envolve o tema da criação da forma de receber as pessoas. Se estamos aceitando que elas entrem, e elas estão entrando, temos que ter uma forma de receber, uma estrutura para receber essas pessoas, que minimamente possa oferecer algum tipo de processo de acolhida, que as pessoas não tenham que ficar dependendo da caridade, ou da ação de instituições que são ligadas a igrejas... aliás, que no Brasil fazem um belíssimo trabalho, mas sobre isso, o Estado deveria ter mais presença nessa questão da acolhida".

"Hoje nós vivemos situações na ponta que sobrecarregam instituições diferentes, muitas das quais já... enfim, vocalizam que não têm capacitação, não têm vocação, nem os incentivos institucionais para cuidar do tema, como a Polícia Federal... algumas que fazem, mas que são constrangidas a atender de uma forma diferente da forma que elas poderiam atender, porque o público delas, ou a estrutura de tomada de decisão delas não privilegia isso".

"Há também interação com a OIM, embora ainda haja problemas na conclusão do processo de adesão à OIM, o que ainda é um obstáculo para sua plena implantação. Apesar disso, a OIM tem contribuído, pois tem uma atuação muito pragmática voltada para a solução de problemas".

Fonte: elaboração do autor. 
Observa-se que os principais desafios correspondem a: defasagem da legislação migratória, falta de políticas de acolhimento aos migrantes, entraves burocráticos no processamento das solicitações dos migrantes a algumas instâncias governamentais, sobrecarga de alguns órgãos para lidar com as demandas decorrentes de fluxos migratórios.

De acordo com a maioria dos entrevistados, em consonância com dados obtidos em pesquisa documental, um dos principais desafios com que atualmente se deparam as instâncias brasileiras que atuam em âmbito migratório corresponde à premente necessidade de atualização da Lei $n^{\circ}$ 6.815/80, tida como antiga e anacrônica (na medida em que conteria elementos tidos como xenófobos, em aversão ao estrangeiro que a lei se destina a controlar), sob um viés de segurança pública ao invés do reconhecimento de direitos. Não obstante, as discussões sobre projetos de atualização do Estatuto do Estrangeiro encontram-se no Poder Legislativo, e muitos apontam falta de sensibilização de lideranças políticas no Congresso Nacional de modo a tratar o tema com a relevância e a tempestividade requeridas.

Salientam-se, ainda, as lacunas decorrentes na atuação das instâncias governamentais no tocante a políticas de acolhimento e de integração dos migrantes no país que os recepcionou. Diversos entrevistados salientaram suas preocupações com o fato de que o país não conta nem com regulamentação dessas políticas, nem com estruturas efetivas voltadas para a execução de tais atividades, relegando-as em grande parte à sociedade civil e a organizações não governamentais que operam em caráter filantrópico.

Como argumenta um dos entrevistados, "não há uma política para os migrantes já estabelecidos. A gente propôs essa política, mas a gente percebe que há setores no governo que têm uma dificuldade em adotar uma política com esse viés. Estamos muito atrasados com uma política de acolhimento”. Por políticas e ações de acolhimento, faz-se referência ao fornecimento de meios pelos quais o não nacional possa integrar-se à sociedade receptora, por meio de direitos, serviços e informações relevantes, a oportunidades para adquirir conhecimentos linguísticos e culturais, ao acesso a emprego, moradia e renda.

Além da lacuna em termos de regulamentação e de estruturas de políticas de integração e acolhimento aos migrantes, deve-se levar em conta que, para executá-las, é necessário aprimorar o relacionamento com outros atores de governo não só no governo federal, como també em Estados e Municípios, e a esse respeito um entrevistado argumenta que se trata de "uma série de fatores que a gente conseguiu muito pouco enfrentar". Ressalta-se, aqui, a importância da estreita concatenação de ações entre as instâncias governamentais, o que será analisado em seguida. 
De acordo com os dados coletados, há reconhecimento de que as instâncias governamentais no Brasil ainda clamam por políticas migratórias mais integradas e consistentes entre si, articulando de forma sistemática e racional a atuação das grandes instâncias envolvidas com a estrutura das migrações - o MTE, o MRE, o MJ, e também considerando o CNIg e o DPF -, bem como possibilitando o envolvimento de outros órgãos governamentais, outras esferas de governo e representantes do setor privado e da sociedade civil. Os entrevistados não divergiram em relação a tal reconhecimento, de modo que um dos entrevistados argumentou que "não me parece que haja um processo de descoordenação. Acho que podemos aprimorar a coordenação, sim, podemos estabelecer melhor as competências de cada órgão", enquanto outro ressaltou que "é apenas por meio do envolvimento e da participação ativa dos envolvidos nos mais diversos níveis, que poderemos formular e praticar uma política migratória realmente efetiva".

Adicionalmente, são tidos como pertinentes os esforços para desenvolver uma acomodação clara de competências entre as diversas instâncias, considerando ainda as interconexões em termos de atuação conjunta. Essa questão também implica racionalizar recursos e projetar programas interministeriais voltados a políticas públicas para os migrantes, em nível institucional. A esse respeito, um dos entrevistados salienta que "envolve também outros níveis, como o político, ou a dificuldade de lidar com a projeção que as pessoas têm a respeito de ganhar espaço, ou de perder espaço para outras instâncias", de modo que devem ser superadas quaisquer concepções de competição entre tais instâncias, e deve ser reconhecida a relevância de uma atuação mais sinérgica entre elas, quaisquer que sejam os desenhos institucionais assumidos nesse âmbito.

Em torno do desenho institucional assumido atualmente, dois órgãos receberam destaque - referidos tanto pelos entrevistados como nos documentos internos - a respeito dos esforços com vistas à articulação e à coordenação da atuação governamental: o DEEST/MJ e o CNIg/MTE. Em termos de aprimoramento dos mecanismos, a maioria dos entrevistados reconheceu o papel fundamental do DEEST/MJ no sentido de coordenar as ações entre os diversos ministérios, de modo um dos entrevistados ilustra esse entendimento ao afirmar que "o MJ tem feito um bom trabalho, articulando entre os órgãos".

Quanto ao CNIg, foi caracterizado como um órgão colegiado de composição quadripartite (com participação de governo, trabalhadores, empregadores e sociedade civil), que formula políticas migratórias e promove interpretações da legislação vigente por meio 
de suas resoluções, as quais podem ser normativas, ou relacionadas a questões laborais, ou à análise de casos omissos, por exemplo. Nesse sentido, corresponde a um "órgão de fundamental importância, e a gente costuma dizer que, se não houvesse o CNIg, não haveria política migratória no Brasil. Porque a lei de 1980, hoje, é extremamente acanhada para os desafios que país hoje tem que enfrentar. Então, se não fosse o CNIg normatizando, acolhendo essas reinvidicações e dando tratamento normativo a elas, não existiria política migratória", conforme salienta um dos entrevistados.

Desse modo, três dos cinco entrevistados no âmbito governamental ressaltaram a importância da atuação do CNIg, sob a ótica da articulação entre os que operam no âmbito migratório. A esse respeito, um dos entrevistados argumenta que " $o$ CNIg atende aos requisitos para atuar como instância para resolução dessas questões de ordem prática, ressalvando que o embate político a respeito do tema deve ser promovido no fórum apropriado, o Legislativo".

Outro entrevistado, por sua vez, ressalta que "as interações não só com os órgãos governamentais, mas com a OIM, a OIT e a Pastoral do Migrante são realizadas no fórum do CNIg, porque eles vão lá como observadores, apresentam seus projetos, e trazem contribuições a partir dessas interações", agregando perspectivas de diversos contextos em um fórum sobre questões migratórias. Nesse contexto, foi apontado que o CNIg, ao atuar como formulador da política, favorece tais interações sob ótica de gestão compartilhada.

Não obstante, dois dos entrevistados, apesar de reconhecer a importância do CNIg, apontaram ressalvas a respeito de sua atuação. Um deles argumenta que, "a respeito do papel do CNIg, é um processo de refinamento constante, porque em termos de política pública a ser implementada, a capacidade de formulação de política pública em um conselho muito grande é muito baixa”. Nessa perspectiva, a capacidade de formulação e a capacidade de discussão de diretrizes poderiam ser comprometidas com a forma de atuação como um conselho com a participação de muitos integrantes, uma vez que, como salienta o entrevistado, "esse conselho se reúne uma vez por mês, especialmente numa realidade que é mais e mais dinâmica. Há quinze anos atrás, talvez, ele desse conta de todo o processo da esfera social que um conselho teria que cumprir, mas cada vez menos isso é factível”.

Outro entrevistado reconhece que, enquanto não houver a aprovação do novo projeto de lei, a lei vigente pode ser apontada como de difícil aplicação, requerendo novas interpretações mais alinhadas aos tempos atuais. Não obstante, argumenta que "cada vez que nós passamos a ter mais clara a interpretação da lei, o espaço disso se racionaliza, isso se 
acomoda. E a gente não precisa ter tantos casos omissos como a gente tem hoje no CNIg, porque a legislação simplesmente não prevê um mecanismo de regularização migratória”, de modo que reconhecer a pertinência de tantos casos omissos seria algo "quase irracional".

Em face disso, os entrevistados se dividem em relação a seus posicionamentos acerca da possibilidade de criação de uma agência governamental criada exclusivamente para tratar das migrações, reunindo competências, atribuições e estruturas que hoje se encontram difusas entre diversas pastas ministeriais. $\mathrm{O}$ debate acerca de tal proposta atualmente se dá no âmbito do Poder Executivo e do Poder Legislativo. Para um dos entrevistados, "seria um retrocesso a criação de uma nova agência, desconsiderando a experiência de gestão compartilhada que conseguimos reunir até agora". Por conta disso, o entrevistado salienta que "a preferência seria pela manutenção da estrutura do CNIg tal como existe hoje".

Outros entrevistados, por sua vez, consideram válido discutir essa proposta. Um deles ressalta "a necessidade de aprimoramentos, de uma estrutura mais concatenada para a coordenação, seja pelo CNIg, seja por uma agência, contanto que se preserve a experiência de gestão conjunta". Outro entrevistado argumenta que "é indiferente aonde estará posicionado hierarquicamente o ente governamental responsável pela política migratória, o importante é que se mantenha o modelo quadripartite (governo, empregadores, trabalhadores, sociedade civil), inclusive em termos de cooperação e de construção de uma cultura compartilhada, com muito respeito em relação aos demais participantes e a preocupação em se chegar a um consenso".

Em suma, enquanto as propostas de nova lei para estrangeiros seguem em tramitação e a propostas sobre a criação de uma nova agência são discutidas em diversos níveis institucionais, observa-se que o clamor por maior articulação e coordenação entre as instâncias governamentais permanecerá por mais algum tempo, sob a forma de uma demanda por alinhamento institucional e por maior governança em âmbito migratório.

É relevante o reconhecimento de que há lacunas em termos de articulação e de coordenação entre as instâncias governamentais, bem como a vontade em superá-las, uma vez que são pertinentes para o êxito das políticas migratórias. Tal reconhecimento, ao desencadear medidas concretas para aprimoramento da governança, pode representar um relevante passo para aperfeiçoar tanto a formulação de políticas integradas como seu processo decisório e sua execução pelos diversos entes governamentais envolvidos, reduzindo a ocorrência de dissonâncias entre as instituições e, por conseguinte, redundância do trabalho, desperdício de recursos e falta de efetividade. 


\section{Percepções de dirigentes de organizações governamentais quanto às migrações}

\section{Quadro 7: Tendências em relação aos fluxos migratórios para o Brasil nos próximos anos}

Perspetivas e projeções a respeito do modo como os fluxos migratórios para o Brasil devem se comportar em curto e médio prazo, levando em conta aspectos relevantes às migrações na conjuntura nacional e internacional, bem como salientando a capacidade e a disposição das instâncias governamentais em monitorar o ambiente migratório e em prospectar seus impactos.

\begin{tabular}{|l|l}
\hline Ocorrências em verbalizações dos entrevistados & \multicolumn{1}{c}{ Ocorrências em documentos internos } \\
\hline - Elevação dos fluxos migratórios para o Brasil & - Estimativas de elevação dos fluxos migratórios \\
- Atualização da legislação sobre estrangeiros & - Tendência que fluxos continuarão a se diversificar \\
- Política migratória mais clara, menos fragmentada & - Persiste a demanda laboral por migrantes \\
- Maior capacidade analítica para formar cenários & - Tramitação do projeto de lei não avançará enquanto \\
- Novo arranjo institucional para lidar com migrações & não houver maior engajamento político \\
\hline
\end{tabular}

\section{Verbalizações desta categoria de análise}

"Caminhamos para a aprovação de uma nova lei para lidar com as migrações. Espera-se por uma menor fragmentação da política migratória no futuro, embora não haja como prever qual a velocidade desse processo".

“Agora, em termos de prognóstico, é muito difícil responder a essa questão. Porque em 2008, 2009, houve uma mudança tão grande, e a gente percebe que os fluxos migratórios são tão dinâmicos, que, qualquer mudança de cenário no país, ou na região, ou mesmo mudança de cenário global, tem impacto sobre as migrações. Então, é difícil dizer o que vai acontecer".

"mantidas as atuais circunstancias, e a gente espera que se mantenha, ou seja, que o Brasil se mantenha com baixo desemprego, e que continue gerando postos de trabalho... tende a uma situação que a Europa já viveu, que é a geração de postos de trabalho que nenhum europeu quer mais assumir aquilo. E isso já está acontecendo no Brasil, já há postos que quem está assumindo são os haitianos, são os ganeses, são os senegaleses, são eles que vão chegando. Então, mantida essa circunstancia, eu creio que as migrações no Brasil vão mudar significativamente nos próximos anos, porque alem das circunstancias serem favoráveis, em termos da teoria de atração e repulsão, ou seja... o Brasil tem sido um polo de atração, e há países que infelizmente continuam sendo um polo de expulsão de pessoas, de diáspora de pessoas, por razoes variadas, mas isso é tudo multiplicado pelo fenômeno de formação das redes. Então, esses migrantes vão formando redes, vão formando comunidades, uma rede mesmo, em que cada um desses se comunica com dez, vinte outros, e as pessoas vêm, e isso vai expandindo, e eu acredito que isso tenha um efeito multiplicador ao longo do tempo".

"Se nós pegamos os dados dos haitianos, em 2010, depois que começaram as migrações depois do terremoto, a gente praticamente multiplica por dez a cada ano o número de haitianos que chega ao Brasil. É possível que este ano a gente chegue a um número próximo de cinquenta mil haitianos no Brasil. E essas novas migrações africanas certamente vão passar pelo mesmo processo".

"Tem limites, também, porque são migrações que dependem não apenas do cenário econômico, mas também do cenário das políticas regionais. Porque não chegam viam Brasil, chegam por meio de outros países, então, tem uma questão conjuntural. Tem outra questão, também, de custos, porque há limites... a migração é cara, a passagem aérea, e as rotas que as pessoas têm que fazer. Então, há limites que podem impactar no numero final, no futuro. Então, eu diria que, ao menos ao curto prazo, a tendência é de forte elevação".

"Me parece que no espaço de desenho e formulação de políticas públicas, nós caminhamos em direção à necessidade de maior capacidade analítica para formar cenários. Cada vez mais a política pública precisa vir não dessa... intermitência, e cada vez mais um processo continuo, capacitado, interligado, que reúna capacidade de analise e obtenção de dados diretos e permanentes, acompanhamento real de movimentos que acontecem em termos de entrada no país, criação de um núcleo de inteligência em torno da questão migratória... e não estritamente policial, ou laboral, ou diplomático, enfim... que seja autonomamente um campo de decisão migratória. Autonomização de um campo de pensamento, de um campo de política publica, exige uma burocracia própria. O caminho natural é essa autonomização de um campo... e eu até amplio, para não falar só da política em si, mas um campo acadêmico, autônomo, de estudos migratórios, e um campo de políticas migratórias próprias, e uma burocracia autônoma. E autônoma em relação claramente ao que a gente tem hoje. De tudo o que foi contribuição de cada uma das instituições. Mas que seja autônoma em relação à segurança, às diversas fiscalizações... essa autonomização desses campos demanda uma burocracia própria, capaz de operar temas migratórios de forma autônoma. Que se forme para isso, que pense nesses termos. E que se module. Não estou pensando em uma burocracia grande, mas uma burocracia que se reconhece como tal".

"instituição de uma agência ou outro órgão para instituir políticas migratórias mais claras, de modo a atrair mão-deobra qualificada, satisfazendo as necessidades laborais de empregadores e as oportunidades de centros de estudos. Ao mesmo tempo, tais políticas devem assegurar o ingresso, o acolhimento e a integração de estrangeiros".

"Os haitianos estão aí, e outros contingentes de estrangeiros, e estão vindo num número cada vez maior. É uma tendência clara. Então, essas questões já estão aí na prática. É surpreendente, porque até 2008 nós não pensávamos nessas questões. E de repente, ocorreu essa mudança de modo tão dinâmico, que em poucos anos há uma inversão de sinal, há uma mudança bastante grande de cenário. Então, de certa forma, isso nos pegou um pouco de surpresa, e temos que nos adaptar para essa mudança".

Fonte: elaboração do autor. 
Acerca das principais tendências para os fluxos migratórios no Brasil em horizontes de curto e médio prazo, os entrevistados argumentaram acerca da dificuldade em projetar cenários diante de processo tão dinâmico e complexo, mas, ainda assim, apontaram algumas prospecções acerca do modo como o âmbito migratório pode se alterar nos próximos anos, dentre as quais: a (forte) elevação dos fluxos migratórios para o Brasil; a perspectiva de atualização da lei para as migrações; a formulação de políticas migratórias mais claras e menos fragmentadas entre várias instituições; o desenvolvimento de maior capacidade analítica por parte das instâncias governamentais para monitorar o ambiente migratório e preparar-se melhor diante das mudanças; e a discussão, reformulação e consolidação de um novo arranjo institucional para lidar com as migrações no Brasil, não apenas em termos da formulação de políticas, mas para implementação de medidas de recepção, registro, acolhimento e integração dos migrantes.

Por meio dos dados obtidos em pesquisa documental junto a relatórios, informes e outros documentos internos, foram reunidas informações que se alinham a tais tendências apontadas pelos entrevistados, sobretudo em termos dos seguintes aspectos: a elaboração de estimativas acerca de tendências para elevação dos fluxos migratórios; informes que sugerem a crescente diversificação dos fluxos em relação a países de origem; prospecções de que, mantida a capacidade de geração de empregos no país, tende a crescer a demanda laboral pelo trabalho dos migrantes; e parecer indicando que a tramitação do projeto de lei $\mathrm{n}^{\circ}$ 5.655 e de outros relacionados à atualização do Estatuto do Estrangeiro depende diretamente de maior sensibilização das lideranças dos partidos políticos no Congresso Nacional, ampliando o reconhecimento da relevância e o engajamento político em torno do tema.

Acerca da tendência de redesenho do arranjo institucional que pode emergir desse processo de reformulação normativo e administrativo em relação ao âmbito migratório no Brasil, alguns entrevistados ressaltaram que tal reconfiguração deve tirar o máximo proveito das estruturas anteriores, seja sob a forma de uma nova agência ou de uma nova conformação de competências a órgãos já existentes.

A esse respeito, um dos entrevistados ressalta a expectativa de que sejam levados em conta os pontos positivos decorrentes da atuação do CNIg como um conselho, argumentando que "apesar de todos esses problemas que a gente vive na questão migratória, acho que nós conseguimos desenvolver um modelo. E por mais que essa lei seja atrasada, e que nós tenhamos inúmeros problemas com essa legislação, pouquíssimos países abrem mão de que seus governos possam estabelecer regras migratórias. E aqui no Brasil, o governo entregou 
a um conselho, que delibera e aprova normas... e hoje a maior parte do conselho é da sociedade civil. Dos vinte membros, nós temos onze que são da sociedade civil, e nove do governo. E, apesar disso, temos uma forma de trabalho que consegue harmonizar interesses, e aprovar normas que atendem aos interesses de todas as partes envolvidas. Então, isso é muito interessante. E é raro de encontrar no mundo. E as decisões são legítimas. Então, assim, há um baixo percentual de questionamento dessas decisões".

Por sua vez, outro entrevistado salienta que "cada órgão do governo tem um papel. Não tem como dizer que as migrações têm dono, ou que vá haver um órgão que vai cuidar de $100 \%$ delas, isso não é possível". Desse modo, mesmo que haja várias formas de se lidar com o fenômeno migratório, "não seria a melhor forma juntar tudo num único órgão. Acho que cada órgão deve ter uma competência que tenha a ver com sua função principal".

\section{4 - Percepções dos representantes de organizações não-governamentais}

São consideradas a seguir as percepções dos representantes de cinco organizações não governamentais que operam em âmbito migratório, quais sejam: o escritório da Organização Internacional do Trabalho no Brasil; o escritório do Alto Comissariado das Nações Unidas para os Refugiados, situado em Brasília; a Organização Internacional para as Migrações (ainda em fase de implantação no Brasil); o Instituto para Migrações e Direitos Humanos, situado em Brasília; e a Missão Paz/Casa do Migrante, situada em São Paulo.

De modo análogo aos demais entrevistados da esfera governamental, firmou-se o compromisso de que nenhuma das verbalizações dos entrevistados em organizações não governamentais seria nominada, de modo a preservar suas identidades. Assim, sempre que detectado na verbalização o emprego de algum termo que pudesse identificar o entrevistado, optou-se por omitir de sua fala o trecho que permitisse tal identificação. Ademais, salientase que tampouco há qualquer tipo de ordenamento ou sequencia pré-definida para a listagem das verbalizações, ou no tocante aos dados coletados com as entrevistas e os documentos internos, de modo que tais elementos também foram propositalmente 'embaralhados'.

A seguir, são considerados os resultados obtidos no que diz respeito a duas categorias de análise em relação às percepções de representantes de organizações não governamentais que atuam em âmbito migratório, conforme os quadros 8 e 9, quais sejam: avaliação de iniciativas governamentais para políticas migratórias efetivas; e avaliação da atuação coordenada entre instâncias governamentais. 
Percepções dos representantes de organizações não governamentais Quadro 8: Avaliação de iniciativas governamentais para políticas migratórias efetivas

Opiniões a respeito da efetividade de ações formuladas e implementadas pelas instâncias governamentais brasileiras em âmbito migratório, em termos de eficácia e eficiência de tais medidas, considerando o atendimento de demandas dos migrantes que se deslocam ao país e o cumprimento de compromissos internacionais assumidos em torno do tema.

\begin{tabular}{|c|c|}
\hline Ocorrências em verbalizações dos entrevistados & Ocorrências em documentos internos \\
\hline $\begin{array}{ll}\text { - } & \text { Faltam políticas públicas claras para os migrantes } \\
\text { - } & \text { Migrações não deviam estar a cargo da polícia } \\
\text { - } & \text { Iniciativas pontuais, não sistemáticas } \\
\text { - } & \text { Disparidade entre discurso e prática de políticas } \\
\text { - } & \text { Governo relega a acolhida à sociedade civil }\end{array}$ & $\begin{array}{l}\text { - Governo federal tentou ordenar fluxos migratório } \\
\text { de não documentados, mas não obteve êxito } \\
\text { - Lacunas em ações públicas para acolher migrante } \\
\text { - Vulnerabilidades para migrantes em nível local } \\
\text { - Apoio de ONG's suprindo o papel do governo }\end{array}$ \\
\hline
\end{tabular}

Verbalizações desta categoria de análise

"Houve avanços, nos últimos anos, isso é inegável, em especial no âmbito do Mercosul. Mas a legislação em vigor teima em não avançar, apesar dos projetos e dos esforços que estão na ordem do dia. O Brasil legisla pontualmente, de acordo com seus interesses, como no caso específico dos haitianos. Legisla com portarias, buscando brechas aqui e ali. Isso em termos de legislação. No campo das políticas públicas, é preciso reconhecer que na área da saúde, os imigrantes que aqui chegam, independentemente da sua situação documental, gozam dos mesmos direitos que os nacionais. Na área da educação básica também houve avanços. Mas, nos demais campos, não há nenhuma política clara voltada para os imigrantes. O Estado brasileiro deixa que os próprios imigrantes se virem, ou que organizações da sociedade civil cuidem deles".

"No campo da legislação, a constituição do grupo de intelectuais que elaborou uma proposta de uma nova lei de migração também constitui parte do esforço para um avanço. Ou seja, há espaços abertos. Urgente seria o governo retirar da competência da Polícia Federal os trâmites realtivos aos migrantes, pois migração é não caso de polícia, e reconhecer a todo imigrante trabalhador o direito de residir legalmente no país".

"Acho que, em termos das medidas adotadas pelo governo brasileiro para atender as demandas dos migrantes, acho que tem progredido bastante. Do que existe hoje, não existia obviamente, não é? Há cerca de uma década atrás. Acho que algumas realizações são muito importantes, sem dúvida nenhuma que houve avanços com o fortalecimento do CNIg, que tem progredido bastante. Tem também essa resolução normativa nr. 106, do Conselho, para estender uma possibilidade de regularização aos imigrantes haitianos, isso mostra que se pode responder à demanda, exigência conjuntural específica, mas também que isso foi desenhado para enfrentar os desafios eventuais para essa comunidade de migrantes. Acho que isso... tem havido avanços importantes".

"o tema da integração da pessoa dentro do país, dentro da sociedade brasileira, normalmente tem sido mais um tema em nível local. Agora, sabemos também que, em nível federal, ainda há muito por fazer”.

"A respeito da avaliação das instâncias governamentais brasileiras no atendimento das demandas dos fluxos migratórios, acho que tem que ver com a realidade da pessoa quando chega ao Brasil. Em geral, eu diria que não é muito satisfatório, porque a gente tem duas demandas que são recorrentes entre os solicitantes de refúgio, e o governo não está prestando o serviço devido. Primeiro, a questão do idioma, porque não existe algo sério por parte do governo brasileiro em termos de preparação das pessoas, de modo sistemático e capaz de atender a demanda, em relação à língua, e a cultura brasileira. Isso não existe hoje de modo sistemático. E a questão da acolhida, que é muito complicada, porque a pessoa chega aqui sem lugar para ficar, e vai ser encaminhada para um albergue normal, onde tem pessoas com situações diversas, como moradores de rua que acabam pegando esse migrante e, por não falar o idioma, o enganam ou o assaltam, esse tipo de coisa. Lá muitas vezes têm pessoas que estão com problemas psíquicos, também, então, os migrantes ficam sujeitos a esse tipo de coisa".

"Aqui, não tem um lugar específico para o recolhimento dessa pessoa, onde se possa dar mais orientações, onde se possa atender às demandas específicas dessa população. Não existe. Essa fragilidade acaba comprometendo o processo de acolhida, porque acaba deixando as pessoas numa situação de risco. Elas chegam aqui numa situação de risco, e não existe um plano de governo para tentar contornar, na prática, a nova situação de risco à qual ela acaba submetida. A pessoa chega sem lugar para ficar, e sem entender nada do que acontece em volta dela. É complicada essa situação".

"Tem uma disparidade entre o discurso de acolhida, e a prática de acolhida, entre o discurso de atenção ao migrante e a prática de atenção ao migrante. E discurso político sempre é um discurso político, não é? Acho que é papel do político também colocar os pontos positivos numa determinada política de governo. A Comigrar, agora, por exemplo, foi um aspecto positivo, embora ainda não se saiba exatamente o resultado da Comigrar, o que vai ficar realmente da Comigrar, mas foi algo que se tentou construir em conjunto, com os diferentes atores, por meio do diálogo. Mas tem que ver quais serão realmente as consequências disso. Então, tem que destacar os pontos positivos, do ponto de vista da política pública, e tem que dar atenção aos pontos que estão sendo negligenciados". "É um desafio para o governo brasileiro lidar com as demandas dos migrantes, e ainda não é o ideal, e está longe do ideal em termos do atendimento dessas demandas das populações migrantes, mas há avanços, no sentido de dialogar em torno de propostas comuns, de reformular dispositivos legais que se encontram defasados, de repensar a divisão de competências entre os entes que são responsáveis pela adoção de medidas na área migratória".

Fonte: elaboração do autor. 
A respeito da avaliação acerca das iniciativas do governo brasileiro em termos de políticas migratórias efetivas, os representantes de organizações não governamentais, de forma geral, destacam que há boa vontade em avançar nesse âmbito, mas as dificuldades ainda são inúmeras. Muitos das dificuldades apontadas pelos entrevistados coincidem com aspectos identificados na Categoria 'Desafios no desenvolvimento de ações institucionais frente às migrações', tais como: marco normativo desatualizado, deficiências nas políticas de acolhimento e integração dos migrantes, adoção de iniciativas pontuais e não sistemáticas, papel exercido pela Polícia Federal em torno de questões migratórias.

Um dos entrevistados afirma que "há muito boas iniciativas por parte do MJ, do MTE e do MRE, temos diálogo constante, e percebe-se o interesse em avançar, tanto na perspectiva dos direitos como na possibilidade de inserção dos migrantes", mas também aponta que "ainda não é o ideal, e está longe do ideal em termos do atendimento dessas demandas das populações migrantes".

Documentos internos obtidos junto a algumas dessas organizações não governamentais ressaltam que a elevação dos fluxos migratórios para o Brasil tende a se perpetuar, impondo desafios à sociedade brasileira, em geral, e aos governantes, em particular. Como apontado em um informe, dezenas de imigrantes cruzaram a fronteira no Norte do Brasil em 2010, e chega-se a 2014 com estimativas que ultrapassam milhares, de modo que as tentativas do governo federal em ordenar esse fluxo foram ultrapassadas por fatos e situações de extrema vulnerabilidade que se instalaram em alguns municípios, principalmente em fronteiras do Norte do país.

A esse respeito, um dos entrevistados argumenta que "o visto humanitário concedido pelo governo brasileiro aos haitianos simboliza esse empenho em suprir as lacunas legais no sentido de desenvolver canais efetivos voltados à solução das demandas desses migrantes, seja por sua vulnerabilidade de sua situação que os impele a sair de seu país de origem, seja pela contribuição que eles podem produzir ao mercado laboral brasileiro". Por outro lado, reconhece que "ainda causa consternação a crônica falta de políticas para acolher o migrante, ou o refugiado, e de integrá-lo à sociedade, de forma digna".

Desse modo, muitos dos entrevistados salientam suas preocupações em relação ao processo de acolhida e de integração dos migrantes, mencionando que sua importância é tão relevante quanto a sua recepção ao cruzar a fronteira. Nesse sentido, esse é, de acordo com a maioria dos entrevistados, "um dos aspectos da questão migratória no Brasil em que mais se pode avançar", no sentido de oferecer aos migrantes tratamento mais digno, informações 
mais claras, estruturas de referência e acesso a emprego e renda, de modo que possam integrar a sociedade de modo pleno, com igualdade de oportunidades, como ressalta o texto constitucional. Essa questão, como afirma um dos entrevistados, envolve reconhecer que " $a$ migração não é um problema, mas acima de tudo um direito, e uma oportunidade para as nações que recebem aqueles novos habitantes, caso trate de reconhecê-los como cidadãos".

Outro entrevistado afirma que "o governo brasileiro parece ter uma política que a gente crê que está no horizonte certo, de proporcionar que esses movimentos migratórios ocorram de modo regular e documentado, e buscando proteção dos direitos humanos". Não obstante, ainda há "várias perguntas e inquéritos sobre o futuro dessa política, muitas em decorrência da falta de definição normativa". É visto como algo positivo o fato de que há vontade manifesta das instâncias do poder executivo em poder evoluir com a reforma da lei 6.815/80, embora ainda haja "questões que não dependem do poder executivo, que dependem de regulamentação pelo poder legislativo, e o tempo que leva essa tramitação".

Nesse cenário, enquanto não se avança em um novo marco regulatório, o representante de um dos organismos internacionais salientou " a fundamental importância da participação da sociedade civil, principalmente de instituições religiosas, como as que integram a Rede Caritas e a Pastoral do Migrante", as quais, com o auxílio de autoridades locais, buscam suprir lacunas deixadas pelo governo federal em relação aos migrantes.

Uma iniciativa que almejou ampliar o envolvimento da sociedade em torno da questão migratória foi a Conferência Nacional sobre Migração e Refúgio - Comigrar, realizada em julho de 2014 na cidade de São Paulo, coordenada pelo MJ, por meio da Secretaria Nacional de Justiça e o DEEST, em parceria com MTE e MRE, com o apoio da OIM e com a participação de migrantes, profissionais envolvidos na temática migratória, estudiosos e representações diversas que vivenciam a realidade da migração, para reflexão e aporte coletivos de insumos para a Política e do Plano Nacionais de Migrações e Refúgio.

A respeito dos resultados da Comigrar, um dos entrevistados argumenta que "pode contribuir se for incorporado em termos da elaboração das políticas públicas no Brasil, parece que essa é a intenção dos atores sociais, inclusive do governo brasileiro, mas tem que se mover e incorporar diretamente as contribuições dessa conferencia". Outro entrevistado salienta que a Comigrar "foi um aspecto positivo, embora ainda não se saiba exatamente o que vai ficar realmente da Comigrar, mas foi algo que se tentou construir em conjunto, com os diferentes atores, por meio do diálogo. Mas tem que ver quais serão realmente as consequências disso". 


\section{Percepções dos representantes de organizações não governamentais Quadro 9: Avaliação da atuação coordenada entre instâncias governamentais}

Opiniões acerca do grau de alinhamento e concatenação de políticas, programas e ações entre os órgãos governamentais que atuam em âmbito migratório, em caráter complementar ou não, considerando prioridades estabelecidas, estruturas constituídas, recursos investidos, canais de diálogo desenvolvidos, princípios evocados e atitudes de seus agentes acerca das migrações.

\begin{tabular}{|c|c|}
\hline $\mathbf{O}$ & Ocorrências em documentos int \\
\hline $\begin{array}{l}- \\
- \\
-\end{array}$ & \\
\hline \multicolumn{2}{|l|}{ Verbalizações desta categoria de análise } \\
\hline \multicolumn{2}{|c|}{$\begin{array}{l}\text { "Sinto que há um clima de colaboração entre as instituições públicas, e destas com a sociedade civil, e de vontade de } \\
\text { avançar. É preciso, porém, distinguir o que são as pessoas, como agentes que atuam no governo, e o que é o } \\
\text { Estado. As pessoas, com suas convicções, tomam decisões pontuais, que podem até ser bem favoráveis, mas é o } \\
\text { Estado que articula e institucionaliza por meio de políticas, de forma mais perene". }\end{array}$} \\
\hline \multicolumn{2}{|c|}{$\begin{array}{l}\text { "A respeito da articulação, acho que isso tem progredido, mas acho que pode ser melhorado. (...) vislumbrando essas } \\
\text { possibilidades de maior coerência, e coordenação, e integração, de políticas públicas através do CNIg. Acho que } \\
\text { (...) pela ênfase que deu ao CNIg, e ao fortalecimento do mandato dos conselheiros, isso mostra que o CNIg é, na } \\
\text { ótica da [denominação de organização omitida], um ponto estratégico focal, exatamente no sentido da sua } \\
\text { pergunta, sobre coerência e coordenação entre esses esforços. Eu entendo que tem ainda muito debate a ser feito } \\
\text { sobre essa questão". }\end{array}$} \\
\hline \multicolumn{2}{|c|}{$\begin{array}{l}\text { "Também cabe ressaltar a grande ramificação que a questão migratória impõe ao governo, de modo que não há } \\
\text { como não se envolver os Estados, os Municípios, os representantes da sociedade civil, as organizações não } \\
\text { governamentais, as entidades de classe, as empresas, os organismos internacionais". }\end{array}$} \\
\hline \multicolumn{2}{|c|}{$\begin{array}{l}\text { "Eu acredito que a tarefa importante para qualquer governo, esse desafio de coordenação, articulação e integração } \\
\text { das agências, dos ministérios de governo. E não apenas em nível federal, mas também estadual e municipal, isso é } \\
\text { absolutamente fundamental. E também de dialogo social constante com [denominação de organização omitida], } \\
\text { entre trabalhadores e empregadores, e outras organizações representativas da sociedade civil, nessa área. Bem } \\
\text { concentradas, em termos de exigências e demandas do desafio migratório para o Brasil". }\end{array}$} \\
\hline \multicolumn{2}{|c|}{$\begin{array}{l}\text { "Acho que o ponto essencial, primeiro, é uma nova lei migratória. Isso é ponto determinante. E isso acaba } \\
\text { influenciando muito o trabalho que realizamos junto ao público de migrantes, porque como a legislação do Brasil } \\
\text { está tão atrasada, várias pessoas que não são refugiados acabam utilizando a solicitação de refúgio para tentar } \\
\text { regularizar sua situação migratória. De modo que a solicitação de refúgio é a única maneira que eles encontram } \\
\text { para ficar aqui e trabalhar. Os migrantes utilizam isso para preencher a lacuna de sua situação migratória. Então, } \\
\text { acho que esse é o principal ponto que tem que ser analisado. Segundo, quem sabe, a criação de estrutura, ou uma } \\
\text { secretaria, ou um órgão de governo, que cuida das demandas e da situação do migrante. Não necessariamente do } \\
\text { migrante, mas por situaçães de risco a que o migrante fica sujeito por ser alguém de fora, a integração e a } \\
\text { acolhida. Acho que falta um órgão de governo que possa integrar ações entre diversos ministérios para focalizar a } \\
\text { situação de migrantes e refugiados". }\end{array}$} \\
\hline \multicolumn{2}{|c|}{$\begin{array}{l}\text { "particularmente acho que essas instâncias não têm agido em conjunto, e a minha impressão é que falta isso, quem } \\
\text { sabe uma secretaria vinculada à Presidência da República, que coordenasse os processos de acolhida e de } \\
\text { integração do migrante. Acho que falta um órgão para trazer diferentes ministérios para trabalhar juntos nessa } \\
\text { questão. Então, a gente vê dois órgãos como o MTE e o MJ, a gente vê que eles estão coordenados e têm diálogo } \\
\text { entre si, mas estão tomando posturas completamente diferentes. O próprio Estatuto do Estrangeiro, agora, com } \\
\text { diversos projetos para se chegar ao novo estatuto... a gente sabe que tem um projeto do MJ, de uma comissão de } \\
\text { especialistas, e do CNIg, também, que vai fazer o seu projeto próprio. Então, isso mostra que a gente não tem uma } \\
\text { coordenação coesa, consolidada, para tratar das questões envolvendo migrantes". }\end{array}$} \\
\hline \multicolumn{2}{|c|}{$\begin{array}{l}\text { "O que também chama a atenção de vários órgãos de governo, do próprio MTE. E também o cumprimento com as } \\
\text { leis brasileiras, inclusive na área do trabalho. Houve aqui algumas situações análogas a tráfico, migrações } \\
\text { involuntárias, no caso dos bolivianos aliciados para trabalhar na área de confecção em São Paulo. Um caso muito } \\
\text { conhecido de fornecedores para grandes marcas de roupas. Então, tem havido essas situações". }\end{array}$} \\
\hline \multicolumn{2}{|c|}{$\begin{array}{l}\text { "A articulação pode ser melhor, pois o que se percebe é que há interesses distintos que ainda não convergiram para } \\
\text { propostas que contemplem a todos os atores. Mas também sem a pretensão de impor respostas unilateralmente. } \\
\text { Seria como uma instância capaz de congregar a política migratória, sob a forma de um fórum, devidamente } \\
\text { legitimada. Dessa forma, todos poderiam expor suas perspectivas, e então, sob algum critério estabelecido } \\
\text { regimentalmente, poderia ser tomada uma decisão em conjunto, e a partir daí acatada por todos os envolvidos. } \\
\text { Qual o nome dessa instituição, ou a que ministério estaria vinculada, ou se ela já existe ou não, para nós essas são } \\
\text { perguntas que não nos competem, contanto que haja essa instância, e que ela passe a funcionar de modo } \\
\text { articulado". }\end{array}$} \\
\hline
\end{tabular}

Fonte: elaboração do autor. 
No que se refere à avaliação da atuação coordenada entre instâncias governamentais, os representantes de organizações não governamentais salientaram que ainda há campo para aprimorar tal atuação, de modo que urge o desenvolvimento de medidas migratórias mais alinhadas entre si. Como argumenta um dos entrevistados, "por situações de risco a que o migrante fica sujeito por ser alguém de fora, a integração e a acolhida, acho que falta um órgão de governo que possa integrar ações entre diversos ministérios para focalizar a situação de migrantes e refugiados".

A esse respeito, é oportuno mencionar que, ao confrontar tais observações com aspectos identificados na Categoria 'Articulação e coordenação das ações entre instâncias governamentais' - a qual faz referências às percepções dos dirigentes de unidades organizacionais que atuam com questões migratórias -, há convergência em termos de alguns dos pontos passíveis de aperfeiçoamento (tais como o clamor por uma política migratória mais coesa e menos pautada por ações pontuais, a importância da atuação do MJ e do CNIg, e a necessidade de articular ações junto a entes de outras esferas de governo). Porém, cabe ressaltar que as percepções dos representantes de organizações não governamentais indicam com maior ênfase não apenas a pertinência, mas a urgência de maior coordenação entre as medidas adotadas pelas instâncias governamentais em torno de questões migratórias.

Ilustra essa questão a identificação de desalinhamentos entre as ações promovidas por algumas instâncias governamentais, na percepção dos entrevistados. Nesse sentido, um dos entrevistados argumenta que "há interesses distintos que ainda não convergiram para propostas que contemplem a todos os atores", enquanto outro entrevistado salienta que " $a$ gente vê dois órgãos como o MTE e o MJ, a gente vê que eles estão coordenados e têm diálogo entre si, mas estão tomando posturas completamente diferentes".

A respeito dessas posturas distintas, o entrevistado faz referência a propostas para reformulação do Estatuto do Estrangeiro, as quais divergem em relação ao entendimento do MJ e do CNIg. Por conseguinte, o entrevistado ressalta que, claramente, "isso mostra que a gente não tem uma coordenação coesa, consolidada, para tratar das questões envolvendo migrantes".

É pertinente ressaltar que muitas dessas organizações não governamentais cujos representantes foram entrevistados vêm atuando no sentido instar aos órgãos de governo que adotem ações mais alinhadas entre si, favorecendo a articulação e a coordenação dessas 
instâncias. Um exemplo é o papel da OIM nesse sentido, por meio de parcerias com órgãos governamentais como o MJ e o MTE de modo a concretizar a Conferência Comigrar, bem como um projeto voltado ao mapeamento das instituições envolvidas na temática migratória no Brasil e com brasileiros no exterior.

O objetivo do projeto, intitulado 'Promoção de direitos no contexto da política migratória brasileira', é o de conhecer a realidade migratória brasileira, além de ampliar e fortalecer o diálogo social entre as principais entidades envolvidas com a temática no país, com a finalidade de revisar políticas públicas, melhorar serviços identificar freios e propor uma nova legislação. Após coletar tais informações, a OIM espera que os principais atores envolvidos possam se reunir para uma discussão aprofundada, a fim de fornecer a base para uma série de recomendações voltadas à definição de políticas migratórias, a fim de assegurar que os direitos dos migrantes estejam incluídos na nova lei de migração do país.

Cabe destacar que, para a maioria dos entrevistados dentre os representantes das organizações não governamentais, a questão dos fluxos migratórios para o Brasil ainda é um problema que necessita de uma ação coordenada, e não de ações pontuais. Como afirma um dos entrevistados, "não se pode colocar ênfase em uma só direção, como a regularização do status migratório, mas é preciso se pensar em políticas que possam permitir a integração dos migrantes na sociedade brasileira, como assim fizeram vários outros imigrantes que aqui chegaram no passado".

Trata-se, sem sombra de dúvida, de um processo longo e que deverá contar com a participação da sociedade civil, do governo e de organismos internacionais, que agora têm pela frente a responsabilidade de dar respostas às demandas dessas comunidades, e de levar o país a concretizar seu discurso de se tornar referência no respeito aos direitos humanos dos migrantes.

\section{5 - Esforços em favor de uma nova política migratória}

Neste tópico, são analisados alguns aspectos mencionados pelos entrevistados e/ou coletados junto à pesquisa documental, em referência a esforços institucionais - alguns inovadores - empreendidos no âmbito das instâncias governamentais brasileiras em favor de novas interpretações, entendimentos e práticas que favorecem a conformação de uma nova política migratória no Brasil. Nesse sentido, serão analisados a seguir: discussões acerca das perspectivas de atualização do Estatuto do Estrangeiro por meio de projetos de reforma do 
marco normativo sobre estrangeiros; atuação do CNIg, com novos posicionamentos e responsabilidades assumidos ao longo dos últimos anos para solucionar questões migratórias; e perspectivas que ensejaram a realização da I Comigrar - Conferência Nacional sobre Migrações e Refúgio, bem como as expectativas em relação aos resultados produzidos pela conferência.

\subsubsection{Projetos de reforma do marco normativo sobre estrangeiros}

Quanto à alteração da normativa interna, algumas tentativas de mudança vêm sendo empreendidas. O Projeto de Lei $n^{\circ} 5.655$, elaborado em 2009, é a mais conhecida delas. Em tramitação no Congresso Nacional, é uma proposta de substituição ao Estatuto do Estrangeiro que alegadamente pauta a aplicação da lei de acordo com os princípios de direitos humanos. No entanto, ainda preserva ideias como a defesa da segurança nacional e a primazia na concessão de visto a pessoas que se enquadram como mão de obra especializada, prevendo diferenças de tratamento conforme esse requisito. Por conta disso, vem sendo apontado pela sociedade civil como uma proposta de teor conservador, diante do quadro jurídico vigente.

Persistem algumas restrições aos estrangeiros no PL n ${ }^{\circ}$ 5.655/09, como a proibição de dirigirem veículos jornalísticos. Vale ressaltar que poucas reivindicações dos movimentos sociais de migrantes foram atendidas, como a transferência de competência dos trâmites burocráticos migratórios para um órgão civil. O PL n ${ }^{\circ}$ 5.655/09 enuncia um rol de direitos de forma geral e abstrata enquanto contém um conjunto de deveres extensos e específicos que restringem a amplitude daqueles direitos. Também propõe a alteração do CNIg para Conselho Nacional de Migrações, fortalecendo seu mandato como formulador da política migratória nacional.

Por conta disso, outro projeto de lei foi elaborado em 2013 pelo senador Aloysio Nunes (PLS n ${ }^{\circ}$ 288/2013). Um dos principais objetivos ancorados neste projeto de lei seria a adequação a princípios democráticos contidos na Constituição Federal de 1988 e a compromissos de direitos humanos firmados pelo Brasil perante o sistema internacional, preocupando-se com a assistência humanitária, a integração regional e a cooperação internacional.

Ainda que em vários aspectos avance em relação ao PL n 5.655/09, os críticos ao PLS n $n^{\circ}$ 288/13 argumentam que suas propostas estabelecem os direitos de forma vaga, sem 
intervir em condicionantes estruturais capazes de promover uma mudança efetiva. Não proporia, por exemplo, a criação de um órgão civil responsável pelo atendimento aos imigrantes, ou de um visto para estrangeiros sem o vínculo empregatício. Nesse contexto, o PLS no 288/13 pode ser caracterizado como tentativa de harmonização da legislação migratória com princípios constitucionais e com os tratados internacionais de direitos humanos, mas sem avançar em propostas de modificações institucionais concretas.

Diante de propostas de mudança na legislação distantes do considerado ideal por especialistas e pela comunidade migrante, em 2013, o Ministério da Justiça, por meio da Portaria $n^{\circ} 2.162 / 13$, criou uma comissão de especialistas com a finalidade de apresentar uma proposta de Anteprojeto de Lei de Migrações e Promoção dos Direitos dos Migrantes no Brasil. Tal comissão promoveu, além de reuniões com representantes do governo, acadêmicos e especialistas, audiências públicas com presença de movimentos sociais e da sociedade civil durante seu processo de elaboração.

$\mathrm{O}$ anteprojeto tem como principais características: a compatibilidade com a Constituição e Tratados Internacionais de Direitos Humanos em vigor no Brasil; a mudança do paradigma da visão sobre imigração, passando do viés securitário para o dos direitos humanos; a unificação de normas dispersas; a participação da sociedade civil; e o objetivo de preparar o país para novos ciclos migratórios internacionais.

Na perspectiva do Ministério da Justiça, a expectativa é que, por meio da discussão em âmbito legislativo em torno dessas propostas de alteração do Estatuto do Estrangeiro - o PL n ${ }^{\circ} 5.655 / 09$, o PLS $n^{\circ}$ 288/13 e o anteprojeto de lei lançado por meio da Portaria $n^{\circ}$ 2.162/13, bem como subsídios decorrentes dos resultados da I Comigrar -, seja promovido um debate erigido democraticamente, deslocando-se de um eixo de 'regime jurídico para estrangeiros' em direção a um 'regime de cidadania dos estrangeiros', considerando os migrantes que vêm ao território nacional.

Essa perspectiva emanada pelo DEEST/MJ, ao ser retomada no debate legislativo, vincularia vetores principiológicos para as propostas de ações em níveis que orbitam em torno dos temas da justiça e da cidadania para estrangeiros. O primeiro nível envolveria suprimir assimetrias de direitos entre nacionais e não-nacionais, entre cidadãos brasileiros e cidadãos estrangeiros fixados no Brasil. A partir dessa perspectiva, seria necessário identificar assimetrias em relação ao acesso a bens, a direitos e a serviços públicos, e minimizar os impactos dessa restrição, com base na nacionalidade, em relação a tal acesso. 
O segundo nível apontado pelo DEEST/MJ envolve a integração do tema das migrações às políticas públicas para que elas sejam eficazes para acomodar, acolher e integrar as pessoas migrantes, o que implica um conjunto de alterações em nível de políticas públicas universais e especializadas de modo a atender plenamente as demandas desses contingentes. E, nesse sentido, busca-se a adequação das políticas públicas para que possam atender de forma mais adequada os migrantes.

Em suma, tais novos enfoques em torno da discussão de propostas de reforma do marco normativo podem efetivamente configurar-se como perspectivas que culminem em nova vinculação entre a realidade migratória e o plano normativo de direitos, de modo que o ordenamento jurídico passaria, ao final desse processo, a conter competências mais claras e mais amplas de modo a lidar com questões de inserção dos estrangeiros sob a ótica de cidadania em sentido amplo.

\subsubsection{Atuação do CNIg na formulação de políticas migratórias}

Em termos gerais, a experiência do CNIg/MTE como formulador de políticas migratórias no Brasil tem sido elogiada por organizações governamentais e não governamentais, por sua composição em bases democráticas e como uma instância que detém competência normativa para opinar sobre a política migratória, bem como por sua ênfase em questões laborais que afetam em grande medida os contingentes de migrantes.

Diante da possibilidade de criação de uma autarquia que lide com a migração, vinculada ao MTE ou ao MJ, ou à Presidência da República, muitos dos participantes da pesquisa salientaram a importância de que a estrutura do CNIg se mantenha, e que sua composição continue sendo quadripartite. Assim, as novas responsabilidades que o CNIg vem assumindo denotam que houve mudanças recentes na forma como se trata a política migratória no Brasil, de modo mais ativo, com enfoque para a migração pautada por direitos humanos e questão laboral, e não só pelo viés da segurança nacional.

Um exemplo dessas novas responsabilidades refere-se à questão humanitária, de modo que, com base no princípio de direitos humanos, foi sinalizada a possibilidade de que essas pessoas possam vir ao Brasil por meio da concessão de um visto humanitário. E a instância que criou esse visto foi o CNIg, por uma questão de direitos humanos, de modo a impedir que aquela pessoa, ao migrar para o Brasil, pudesse ser vítima do tráfico de pessoas ou do trabalho escravo enquanto não tivesse sua situação regularizada. 
Desse modo, o CNIg acabou sendo demandado para solucionar problemas que, originalmente, não estariam em sua área de atuação, por não dizerem respeito à questão laboral. Como exemplos, algumas resoluções emitidas pelo CNIg a respeito da permanência com base em reunião familiar, da permanência com base em união estável, ou do modo como estrangeiros que cumprem pena no Brasil podem ter acesso a documentos acerca da liberdade condicional ou da progressão de regime. Como havia um clamor em relação a esses temas na sociedade, o CNIg trouxe para discussão em seu fórum e os normatizou. Poder-se-ia alegar que essas questões, afetas à competência de outras instâncias, não deveriam estar com o CNIg, mas por falta de atuação de outras instâncias, o CNIg passou a ser demandado e vem se engajando no sentido de dar respostas a essas demandas em termos de política migratória.

Tal é o papel que o CNIg tem se proposto a cumprir, diante da legislação desatualizada, ainda sob o viés da segurança nacional, onde o estrangeiro é considerado um agente potencialmente nocivo. Diante desse quadro, o conselho promove uma releitura da Lei $\mathrm{n}^{\mathrm{o}} 6.815 / 80$ - enquanto as propostas de reforma ainda são discutidas em âmbito legislativo -, pautada por garantias constitucionais e de forma democrática, para que ditames do Estado considerados como excludentes pudessem ser revistos. Nesse sentido, alguns entes da sociedade civil salientam que, efetivamente, o CNIg se reinventou nos anos 90, ganhando maior capacidade para compor debates e encontrar soluções para questões migratórias prementes, com políticas sustentáveis e discurso firmado em direitos humanos. Nesse prisma, o CNIg se consolida no aparato institucional brasileiro e, cada vez mais, como importante espaço de articulação de políticas vinculadas à questão migratória e laboral.

Ao alargar as possibilidades migratórias e estabelecer novos canais de ingresso para os migrantes, o CNIg também trata de desconstruir o imaginário de que o trabalhador estrangeiro migra para retirar o trabalho dos nacionais. Desse modo, o conselho conseguiu estabelecer, ao longo dos últimos anos, diversas novas possibilidades de vinda, como no caso do visto humanitário para a migração dos haitianos, e também no caso dos solicitantes de refúgio que em verdade têm motivação laboral, atuando junto CONARE de modo a criar meios para regularizar a situação migratória dessas pessoas.

Nesse contexto, discute-se a ampliação do CNIg e o fortalecimento de seu mandato como formulador da políca migratória nacional, de modo que, pela proposta que consta no PL n ${ }^{\circ} 5.655 / 09$, o conselho passa a se intitular Conselho Nacional das Migrações, com novos representantes, participação de representantes de grupos de emigrados e de grupos de 
migrantes. Além disso, essa mudança envolveria uma série de novas políticas de cunho migratório, inclusive para o brasileiro que migra para o exterior, ou que está retornando para o Brasil.

O CNIg também vem atuando de modo a firmar parcerias com diversos organismos não governamentais, tais como a OIM e a OIT, de modo que alguns deles têm acesso ao CNIg com o status de observadores. A esse respeito, destaca-se a celebração de um termo de cooperação com a OIT para apoiar no aprimoramento das políticas migratórias, e com o objetivo de implementar mais centros de informação para os migrantes - tais como o que já foi implantado na Casa do Migrante, em Foz do Iguaçu -, onde o migrante pode receber orientações e encaminhamentos, seja para retirar documentos, ou para atividades de assistência social, ou para conseguir emprego de modo mais ágil.

Em suma, por meio dos papéis assumidos pelo CNIg e pelas responsabilidades evocadas, o conselho se insere em um cenário marcado por alguns princípios: migrações como um direito; visão positiva das migrações; possibilidade de qualquer pessoa, independente de quem seja ou de suas qualificações, poder trabalhar e obter seus documentos; e uma política ativa de recepção aos que migram para o Brasil, contribuindo para desenvolvimento mais rápido do país.

Embora algumas instâncias governamentais questionem a capacidade de o CNIg estabelecer diretrizes e gerenciar a política migratória por meio de um conselho composto por tantos integrantes, e em que pese o reconhecimento por parte do conselho de que há divergências e formas distintas de entendimento nesse escopo, é inegável que o CNIg tem conseguido avançar bastante em seu papel como formulador de políticas migratórias no Brasil, bem como nesse posicionamento sobre as migrações internacionais como um direito. Salienta-se, acima de tudo, a transformação pela qual passou o CNIg, de um órgão inicialmente desenhado para exercer o controle sobre a migração laboral para uma instância que se configura como um fórum efetivo para debates na formulação de políticas e fornecimento de respostas institucionais às demandas migratórias no Brasil.

\subsubsection{Perspectivas decorrentes da I Comigrar}

A Conferência Nacional sobre Migrações e Refúgio, como uma primeira experiência - pois a intenção de seus organizadores é que ocorram regularmente outras conferências similares -, foi avaliada por diversos entes da sociedade civil como uma iniciativa positiva 
das instâncias governamentais envolvidas com sua preparação, em termos de apresentar e discutir propostas em torno dos mais diversos temas que afetam a situação no território nacional dos estrangeiros, em geral, e dos migrantes, em particular.

A conferência nacional - precedida de inúmeras conferências regionais e locais realizadas em todo o país - foi realizada em julho de 2014 na cidade de São Paulo, com a coordenação do MJ, por meio da Secretaria Nacional de Justiça e do DEEST, em parceria com MTE e MRE, com o apoio da OIM e com a participação de migrantes, profissionais envolvidos na temática migratória, estudiosos e representações diversas que vivenciam a realidade da migração, para reflexão e aporte coletivos de insumos para a Política e do Plano Nacionais de Migrações e Refúgio.

Foram quase 800 participantes, o que, na percepção dos organizadores, movimentou estruturas nacionais e internacionais, a fim de colocar em discussão aspectos da migração contemporânea com um olhar mais universal sobre a questão, compreendendo a migração sobre o enfoque do desenvolvimento. Assim, a Comigrar buscou contribuir para essa questão, de modo que os migrantes não fossem vistos apenas como um elemento isolado, mas que pudesse se articular, discutir e lançar propostas de aprimoramento de políticas migratórias.

Por meio de uma experiência como a Comigrar, algumas instâncias do governo brasileiro sinalizam a migração como um componente inserido dentro do conceito de desenvolvimento sustentável, pois é inegavelmente um conceito de riqueza, tanto para o país que fornece a mão de obra - por meio das remessas do migrante para o exterior -, como para o país de destino, que necessita dessa mão de obra, sobretudo naqueles países em que há envelhecimento da população, e a mão de obra do migrante é essencial. Esse também foi um dos fatores que impulsionou a realização da Comigrar, de acordo com seus organizadores, de modo a incentivar que as instituições brasileiras na área da migração passassem a compreender as migrações como um fator de desenvolvimento sustentável, e também como um fenômeno inevitável.

Tal reconhecimento também faz referência ao entendimento de que nem mesmo países em que há criminalização da imigração irregular têm sido capazes de deter a imigração, uma vez que aspectos de sobrevivência acabam se sobrepondo aos aspectos legais. Nesse contexto, o que acaba ocorrendo é que a própria lei restritiva, em algum momento, acaba sendo revista, tão logo questões laborais ou econômicas justifiquem a incorporação daqueles contingentes, por meio de anistias ou outros meios de regularização. 
Conforme foi reforçado durante a Comigrar, o migrante em situação irregular não deve ser tratado como ilegal, mas sim como uma pessoa com uma situação administrativa em vias de regularização.

Cabe destacar a participação maciça da sociedade civil e de organizações não governamentais durante a Comigrar, sobretudo a da OIM, que participou não apenas das discussões, mas também de preparação da conferência em parceria com instâncias governamentais, voltadas à mobilização e à logística requeridas, com intuito de fomentar a participação e recolher sugestões para o estabelecimento de políticas públicas voltadas para os migrantes.

A OIM salienta que, como foi a primeira vez que uma experiência ocorreu por iniciativa do poder público no Brasil, ainda há importantes aprimoramentos para que os resultados se concretizem, uma vez que o caminho entre o discurso e a prática é longo, mas apontando claramente para um novo momento no trato da questão migratória. Dentre tais aprimoramentos, o reconhecimento de que a Comigrar, como uma experiência muito válida, precisaria envolver ainda mais órgãos e outras organizações da sociedade civil, e que as ONG's pudessem ter mais acesso como observadores no âmbito de próximas iniciativas similares a essa conferência.

A respeito das expectativas do DEEST/MJ em relação à Comigrar, envolvem sobretudo o encaminhamento de subsídios para as propostas de reformulação do marco normativo sobre estrangeiros no Brasil. Nesse sentido, tais contribuições da conferência podem ser úteis para configurar um desenho do projeto de modo a mapear as redes de migrantes e a conformar as propostas em âmbito legislativo, bem como formatar críticas e monitorar o processo de reforma do Estatuto do Estrangeiro. A Comigrar buscou, assim, promover diálogo com a sociedade civil que executa medidas de apoio aos migrantes, suplementando a atuação do Estado.

No desenho da metodologia da Comigrar, estabeleceu-se que, nos meses que antecederam a conferência nacional, qualquer grupo acima de sete pessoas pudesse, por meio de conferências locais junto a grupos de migrantes e com o apoio de entes da sociedade civil, indicar delegados para o encontro nacional. Acima de tudo, ensejou-se um processo participativo, com capilaridade estadual, distrital e municipal.

O DEEST/MJ, a esse respeito, argumenta que tal processo foi de certo modo anárquico e autoimpulsionado, o que foi apontado como intencional, uma vez que a ideia era que o protagonismo nesse processo de escolha dos delegados fosse dos participantes: 
nacionais e/ou estrangeiros, permanentes e/ou provisórios, regulares e/ou nãodocumentados, refugiados e/ou solicitantes de refúgio. Ao final das conferências locais e regionais, caracterizadas como 'conferências livres', todas as propostas foram consolidadas em um caderno de propostas para o encontro nacional.

A título de exemplo, são mencionadas a seguir algumas dentre as propostas selecionadas para discussão na Comigrar nacional, a partir de uma conferência livre realizada na UnB, com participação de professores e estudantes, entre nacionais e não nacionais:

- Devem ser aprimoradas a disposição e a divulgação de informações sobre os direitos dos estrangeiros.

- Devem ser assegurados direitos de proteção e de combate à violência, e a preparação e o atendimento apropriado aos estrangeiros por parte dos órgãos que coíbem a violência.

- Devem ser cumpridos os compromissos em torno das garantias de leis de igualdade e justiça entre brasileiros e estrangeiros.

- Devem ser aprimorados os canais para participação dos estrangeiros nos processos de formulação da política migratória no Brasil.

- Deve ser mantida a mobilização para que tais propostas avancem em termos de um projeto de lei. Demonstra-se preocupação em relação aos documentos elaborados na Comigrar, por ainda não haver clareza do modo como serão levados em consideração nesse processo de atualização das leis para estrangeiros.

- Devem ser criados núcleos de apoio fossem criados nas regiões onde se concentra um maior número de imigrantes. Essa descentralização permitiria a agilização dos processos e a melhoria dos serviços. Outro ponto relevante é a possibilidade de contar com pessoal que entenda idiomas estrangeiros nos pontos de atendimento aos imigrantes.

Quanto aos resultados da conferência, o DEEST/MJ salientou que foram compartilhados com todos os ministérios que atuam na área migratória, bem como com instâncias do Legislativo, sob a forma de um caderno final com as propostas. Um caderno de insumos cuja ideia não foi a de hierarquizar, mas salientar as propostas mais recorrentes.

Nesse contexto, a Comigrar pode ser apontada como uma experiência positiva e exitosa em relação a vários aspectos, ao envolver órgãos de diversas esferas de governo com 
um plano para sensibilização da realidade migratória, também voltado para: mapear formas de articulação interna no âmbito da sociedade civil, após décadas de supressão à autoorganização; formar lideranças em torno desse tema, e gerar multiplicadores; e ensejar o fornecimento de respostas mais rápidas, com estruturas de atendimento mais preparadas e capacitadas.

A respeito das perspectivas de que Comigrar tenha cumprido plenamente esses objetivos, cabe destacar a preocupação expressa por alguns representantes de organizações não governamentais que participaram desta pesquisa, bem como mencionado em dados coletados junto a documentos internos. Nesse sentido, os participantes da conferência ainda detêm pouco ou nenhum conhecimento acerca do modo como as propostas emanadas poderão se concretizar em termos de um novo marco normativo, uma vez que não há delimitação clara do modo como o caderno final de propostas será tratado em termos da discussão dos projetos de lei no âmbito do Poder Legislativo. E salientam que tais propostas, para que a experiência da Comigrar seja realmente válida, devem ter o devido tratamento e atenção nesse debate.

O DEEST/MJ salienta que, a partir de agora, a população detém autotutela em torno dessa questão, de modo que a coordenação tripartite entre MJ, MTE e MRE não necessariamente tratará de vincular-se aos resultados da conferência conforme suas discussões em âmbito legislativo, com independência para quem produz os resultados, e independência para quem recebe os resultados. Preconiza-se, nesse sentido, a promoção de um debate aberto, a partir do impulso despertado pela Comigrar, e uma vez despertado, não se pode mais retê-lo. Nesse sentido, acima de tudo, a Comigrar realimenta as instâncias governamentais que atuam com as migrações, por meio de reflexões, recomendações e propostas de aprimoramento.

Por fim, denota-se que as instâncias governamentais brasileiras, sobretudo o DEEST/MJ e o CNIg/MTE, vêm se esforçando no sentido de promover ajustes na forma como as questões migratórias no Brasil têm sido tratadas. Por meio de medidas como as propostas de reforma do marco normativo, novas responsabilidades assumidas e iniciativas para reunir diversos segmentos vinculados aos migrantes para discutir propostas que aprimorem as políticas migratórias no país, tais instâncias denotam sua disposição em avançar, embora ainda haja um longo caminho pela frente, até que os migrantes possam ser apropriadamente recepcionados, acolhidos e integrados à sociedade brasileira. 


\section{5 - Considerações Finais}

O objetivo deste estudo foi o de examinar medidas implementadas por organizações públicas brasileiras no âmbito das migrações de pessoas, bem como caracterizar sua atuação, considerando aspectos específicos, articulação institucional e desafios inerentes aos fluxos migratórios de pessoas para o Brasil no início do século XXI. A esse respeito, pode-se afirmar que não há uniformidade nem unicidade na resposta institucional das instâncias governamentais brasileiras, a qual pudesse configurar-se como uma política nacional de imigração coesa e integrada, mas, sim, uma pluralidade de respostas institucionais, o que decorre da multiplicidade de atores envolvidos nos mais diversos âmbitos, bem como diversidade de interesses, perspectivas e posicionamentos acerca do tema.

Tal configuração requer, acima de tudo, enormes esforços voltados para a articulação e para a coordenação dessas respostas institucionais entre si e em relação às ações da comunidade internacional, embora até o momento tenham predominado iniciativas pontuais em relação a mecanismos e estruturas voltados a soluções mais amplas e sistemáticas. Não obstante, cada vez mais as respostas se aproximam de um eixo comum, em torno da proteção aos direitos dos migrantes, da compreensão das migrações sob o enfoque laboral e da necessidade de convergência das ações para que os não nacionais tenham acesso a políticas claras, que lhes possibilitem melhores condições de vida e que favoreçam sua acolhida e sua integração à sociedade brasileira.

Desse modo, o governo brasileiro vem se aprimorando não em torno de uma única política nacional de imigração, mas de várias medidas migratórias que por vezes são dissonantes entre si. Há avanços claros nesse processo ao longo dos últimos anos, mas, ainda assim, está longe do ideal. Esse aprimoramento vem ocorrendo, ainda de forma pontual, mas com diversos sinais de que tende a sistematizar-se, a partir das iniciativas de alguns órgãos que acabam estimulando que outros órgãos que também trabalham com o tema também busquem se atualizar. Desse modo, é cabível afirmar que, ao longo dos últimos anos, há um aprimoramento da atuação das instâncias governamentais brasileiras em torno das migrações, sobretudo por meio de um amadurecimento das discussões.

A esse respeito, os papéis exercidos pelo DEEST/MJ e pelo CNIg/MTE têm sido fundamentais, ao buscar articular os atores envolvidos, ao tratar de congregar diversas perspectivas distintas e incitar o desenvolvimento de soluções conjuntas para os desafios que 
afetam as questões migratórias, seja por meio da formulação de políticas, seja pela emissão de resoluções normativas. Conforme essa sistemática de funcionamento, alicerçada sobre uma gestão compartilhada e calcada em princípios democráticos, as situações que vão sendo debatidas nessas instâncias culminam em estímulos à troca de experiência e à conformação de entendimentos acerca da temática, as quais são extrapoladas para outros âmbitos de atuação institucional, dentro e fora do governo.

No entanto, ainda há grandes desafios a ser superados, dentre os quais a revisão do marco normativo, e a concretização de políticas efetivas para acolhimento e integração dos migrantes. Nesse sentido, na medida em que o país adote política de acolhimento, devem ser criadas estruturas preparadas para promover tal recepção, capacitadas para prestar tal atendimento e ramificadas por todo o território nacional, de modo que haja locais onde os estrangeiros possam ter assegurado seu acesso a direitos e cidadania.

Cabe, ainda, uma avaliação se deveria ser mantida, ou não, a estrutura institucional vigente, com a atual repartição de competências entre as instâncias governamentais do MJ, do MTE e do MRE, bem como a discussão acerca da competência da Polícia Federal não só para registrar como para expedir documentos dos estrangeiros no Brasil, a qual foi salientada por muitos dos entrevistados como um aspecto a ser ajustado, mediante a criação de uma estrutura burocrática específica para promover tal atendimento. Como argumentou um dos entrevistados, migração não seria assunto de polícia, mas, sim, de um serviço que os tratasse dignamente e que fosse preparado para apoiar o pleno atendimento de suas demandas.

Há que se reconhecer, no âmbito das instâncias governamentais brasileiras, sinais dos desafios envolvidos para calibrar as estruturas democráticas em torno do tema. Salienta-se, ainda, a necessidade de fomentar o diálogo interfederativo em torno das questões migratórias, levando em conta que há vulnerabilidades sociais que acometem os migrantes não apenas nas grandes metrópoles, como também em determinados contextos locais nos quais os impactos dos fluxos migratórios têm se manifestado com mais intensidade - tais como algumas localidades fronteiriças na Região Norte do Brasil. Salienta-se, ainda, o risco da importação de conceitos e categorias no contexto migratório que não têm base histórica no Brasil, a exemplo de comportamentos xenófobos e aversão a estrangeiros, levando em conta a marcada influência dos migrantes na composição da sociedade brasileira.

Nesse sentido, deve ser frisado o argumento proferido por alguns dos entrevistados, de que nenhuma lei conseguirá controlar e/ou limitar por completo os fluxos migratórios, de modo que muito mais racional é o entendimento das migrações como relevante 
impulsionador do desenvolvimento econômico e social por meio dos fluxos de pessoas, recursos e informações. Há, assim, espaço para que soluções institucionais sejam debatidas e resultem em medidas concretas sob a forma de uma política nacional de migração coesa e integrada, a qual ainda se encontra em fase de construção, a partir da revisão da legislação migratória e da reconfiguração de um aparato institucional capaz de atender plenamente às demandas dos migrantes.

Em suma, é em torno da identificação e da discussão desses aspectos que se configuram as principais contribuições da pesquisa, apresentando como se caracterizam os fluxos migratórios para o Brasil no início do século XXI, a partir de uma perspectiva institucional, bem como evidenciando aspectos pertinentes a atuação das instâncias governamentais que operam nesse contexto.

Dessa forma, em termos de princípios norteadores das ações institucionais em torno das migrações, foi identificada a influência dos seguintes princípios: migração como um direito; respeito aos direitos humanos; prestação de apoio em caráter humanitário; exercício da soberania; proteção das fronteiras nacionais; reciprocidade no trato com outros países; segurança nacional; e proteção da mão-de-obra nacional.

Quanto aos desafios ao desenvolvimento de ações institucionais frente às migrações, os dados obtidos com a pesquisa documental e com as entrevistas possibilitam a identificação dos seguintes aspectos que devem ser superados com vistas a formulação e implementação de políticas migratórias mais efetivas: defasagem da legislação migratória; falta de políticas de acolhimento e de integração aos migrantes; entraves burocráticos no processamento das solicitações dos migrantes em algumas instâncias governamentais; sobrecarga de alguns órgãos para lidar com as demandas decorrentes de fluxos migratórios.

Acerca de tendências em relação aos fluxos migratórios para o Brasil nos próximos anos, foram apontadas as seguintes projeções e estimativas: elevação na intensidade e na diversificação dos fluxos migratórios para o país; persistência da demanda laboral por trabalhadores migrantes; definição do novo marco normativo sobre migrações que possibilite a formulação de políticas migratórias mais claras; novo arranjo institucional para lidar com migrações.

Quanto à avaliação de iniciativas governamentais para formulação e implementação de políticas migratórias efetivas, os entrevistados manifestaram, dentre outras observações: o reconheciento de que há vontade em aprimorar a atuação institucional, mas que ainda não se concretizaram plenamente; falta de clareza nas políticas públicas para migrantes; lacunas em 
ações públicas para acolhimento e integração dos migrantes, relegadas à sociedade civil; iniciativas governamentais pontuais e não sistemáticas.

Por sua vez, ao avaliar a articulação e a coordenação entre instâncias governamentais, os participantes das entrevistas salientaram: o papel do CNIg/MTE e do DEEST/MJ de modo a fomentar a atuação conjunta; pontos de aprimoramento na coordenação; predomínio de iniciativas pontuais; ausência de uma política migratória coesa; composição do CNIg favorece soluções conjuntas; necessidade de ampliar participação de outras instâncias, bem como das esferas federal e municipal; necessidade de aprimoramento na articulação, na coordenação e na institucionalização de políticas públicas no âmbito migratório; disparidades entre o discurso e a prática em diversas instâncias governamentais; falta de convergência em decorrência de interesses distintos na atuação dessas instâncias; ensejo de envolver outras esferas de governo que lidam com migrações e fortalecer o diálogo entre tais instâncias.

Por fim, em termos de esforços em favor da definição nova(s) política(s) migratória(s) no Brasil, foi conferida especial atenção aos seguintes aspectos: discussões acerca das perspectivas de atualização do Estatuto do Estrangeiro por meio de projetos de reforma do marco normativo sobre estrangeiros; atuação do CNIg, com novos posicionamentos e responsabilidades assumidos ao longo dos últimos anos para solucionar questões migratórias; e perspectivas que ensejaram a realização da Comigrar, bem como as expectativas em relação aos resultados produzidos pela conferência

Os aspectos identificados no decorrer dessa pesquisa, além de salientar as percepções de instâncias diretamente envolvidas acerca da questão migratória em anos recentes, podem contribuir no sentido de fornecer um diagnóstico acerca dos avanços experimentados até agora, e acerca de quais os principais pontos passíveis de aprimoramento. Nesse sentido, os resultados obtidos são particularmente relevantes para formuladores e implementadores de políticas migratórias no Brasil, de modo a subsidiar ações enfocadas no fortalecimento dos aspectos positivos identificados e na superação de aspectos apontados como frágeis, e que ainda carecem de ação institucional mais efetiva.

Em termos de recomendações para estudos futuros, sugere-se que os pesquisadores dessa temática levem em conta, a partir da identificação de indícios acerca de disparidades entre o discurso e a prática no âmbito das instâncias governamentais que operam no âmbito migratório, o emprego da análise do discurso de modo entremeado à análise de conteúdo em relação aos dados coletados, de modo a evidenciar de modo mais contundente tais distinções 
que aparentam exercer influência significativa sobre os esforços para uma atuação mais articulada e coordenada entre tais instâncias.

Adicionalmente, sugere-se a opção por pesquisa longitudinal, ao invés de transversal, no sentido de identificar novos casos e aspectos relevantes à atuação dessas instituições, bem como que se acompanhe de que forma se concretizam, ou não, as tendências apontadas para as migrações nos próximos anos, a partir novas investigações em torno dessa temática, inclusive com a possibilidade de emprego de técnicas de pesquisa não apenas de cunho qualitativo, como também de cunho quantitativo.

Conclui-se que as respostas institucionais do governo brasileiro diante das questões migratórias, embora tenham evoluído em termos de novos posicionamentos em relação ao tema, ainda carecem de articulação e coordenação mais estreita entre as várias instâncias, assim como de maior atenção ao acolhimento e à integração dos migrantes à sociedade brasileira, de modo que se salienta a necessidade de avançar nesse sentido para que haja aprimoramento na atuação dessas instâncias e maior efetividade das políticas migratórias brasileiras, bem como maior correspondência entre o discurso e a prática em torno da questão migratória no Brasil. 


\section{REFERÊNCIAS}

ASSAD, L. Nova onda de estrangeiros chega ao Brasil. Revista Ciência e Cultura, v. 64, n.2, abr/jun. 2012, p. 29-44.

BAENINGER, R. Rotatividade migratória: um novo olhar para as migrações no século XXI. In: ENCONTRO NACIONAL DE ESTUDOS POPULACIONAIS, 16., 2008, Caxambu. Anais... Belo Horizonte: Associação Brasileira de Estudos Populacionais - ABEP, 2008. Disponível em: <http://www.abep.nepo.unicamp.br/encontro2008/docsPDF/ABEP2008_1254.pdf>. Acesso em: outubro 2014.

Notas acerca das migrações internacionais no século 21. In: ENCONTRO NACIONAL DE PÓS-GRADUAÇÃ̃ E PESQUISA EM CIÊNCIAS SOCIAIS, 37., 2013, Águas de Lindóia-SP. Anais... São Paulo: Associação Nacional de Pós-Graduação e Pesquisa em Ciências Sociais - ANPOCS, 2013. Disponível em: <http://portal.anpocs.org/portal/index.php?option=com_docman\&task=doc_details\&gid=8626\&Itemid=459>. Acesso em: outubro 2014.

BASSANEZI, M. S. C. B. et al. Atlas de imigração internacional em São Paulo 18501950. São Paulo: Ed. UNESP, 2008.

BATISTA, V. O. O fluxo migratório mundial e o paradigma contemporâneo da segurança migratória. Revista Versus, v. 3, p. 28-78, 2009.

BEIGUELMAN, P. A crise do escravismo e a grande imigração. São Paulo: Ed. Brasiliense, 1981.

BIZERRIL, J. Migrações: atravessando fronteiras nacionais, cruzando fronteiras disciplinares. In: PEREIRA, G. M. S.; PEREIRA, J. R. S. (Orgs), Migração e globalização: um olhar interdisciplinar. Curitiba: Editora CRV, 2012.

BOURDIEU, P. O poder simbólico. Rio de Janeiro: Bertrand Brasil, 2012.

CASTLES, S. ; MILLER, M. J. The age of migration: international population movements in the modern world. 4.ed. Londres: Palgrave Macmillan, 2009.

CASTRO, A. G. Abordagens teóricas da migração internacional. Revista Interdisciplinar, n. 5, p.23-29, 2011.

CAVALCANTI, L. Imigrantes, imigrados, estrangeiros... e a fabricação do outro imaginário. A presença brasileira no contexto da imigração na Espanha. Revista: Universitas Comunicação, v. 3, p. 37-52, 2005.

; PARELLA, S. El retorno desde una perspectiva transnacional. Revista Interdisciplinar de Mobilidade Humana - REMHU, v. 21, p. 9-20, 2013. 
; SIMOES, G. Assimilacionismo x multiculturalismo: reflexões teóricas sobre os modelos de recepção dos imigrantes. ESFERAS - Revista Interprogramas de Pós-graduação em Comunicação do Centro Oeste, v. 3, p. 153, 2013.

; OLIVEIRA, A. T.; TONHATI, T. (Orgs.) A inserção dos imigrantes no mercado de trabalho brasileiro. Brasília: Cadernos do Observatório das Migrações Internacionais, 2014. Disponível em: <http://portal.mte.gov.br/obmigra/imigracao>. Acesso em: 20/11/2014.

CERVO, A. L. Inserção internacional: formação dos conceitos brasileiros. São Paulo: Saraiva, 2008.

; BUENO, C. História da política exterior do Brasil. 3.ed. Brasília: Ed. UnB, 2008.

COGO, D. M. ; SOUZA, M. B. Guia das migrações transnacionais e diversidade cultural para comunicadores. Bellaterra: Instituto Humanitas Unisinos; Instituto de la Comunicación de la UAB, 2013.

DUTRA, D. Migração internacional e trabalho doméstico: mulheres peruanas em Brasília. Brasília: CSEM, 2013.

EISENHARDT, K. M. Building theories from case study research. The Academy and Management Review, v.14, n.4, p.532-550, 1989.

FRANCO, K. L. P. B. Análise de conteúdo. Brasília: Plano, 2003.

GÓIS, P. et al. Segunda ou terceira vaga? As características da imigração brasileira recente em Portugal. Revista Migrações, n.5, p. 111-133, 2009. Disponível em: <www.oi.acidi.gov.pt/docs/Revista_5/Migr5_Sec1_Art6.pdf> . Acesso em: outubro de 2014.

GURAK, D. ; CACES, F. Redes migratorias y la formación de sistemas de migración. In: MALGESINI, G. (org), Cruzando fronteras: migraciones em el sistema mundial. Barcelona: Icaria-Fundación Hogar del Empleado, 1998.

HAESBAERT, R. O mito da desterritorialização: do fim dos território à multiterritorialidade. $2^{\mathrm{a}}$ ed. Rio de Janeiro: Bertrand Brasil, 2006.

HELD, D. ; MCGREW, A. Prós e contras da globalização. Rio de Janeiro: Jorge Zahar, 2001.

KING, G. ; KEOHANE, R. ; VERBA, S. Designing social inquiry. London: Princeton University Press, 1996.

KING, N. Using interviews in qualitative research. In: SYMON, G.; CASSELL, C. (Org.), Essencial guide to qualitative methods in organizacional research. London: Sage, 2004, cap. 2.

KRISSMAN, F. Sin coyote ni patrón: why the "migrant network" fails to explain international migration. International Migration Review, v. 39, n. 1, p. 1-44, 2005. 
LOPES, C. M. S. Direito de imigração: o Estatuto do Estrangeiro em uma perspectiva de direitos humanos. Porto Alegre: Núria Fabris, 2009.

LÜDKE, M. ; ANDRÉ, M. L. Pesquisa em educação: abordagens qualitativas. 6.reimp. São Paulo: EPU, 1986.

MARINUCCI, R. ; MILESI, R. Migrações internacionais contemporâneas. IMDH, junho 2005. Disponível em: <http://www.migrante.org.br/as_migracoes_internacionais_contemporaneas_160505b.htm>. Acesso em: outubro de 2014.

MASSEY, D. et al. Theories of international migration: a review and appraisal. Population and Development Review, v. 19, n. 3, p.431-466, 1993.

Theories of international migration: a review and appraisal. In: MESSINA, A. L. (Org.), The migration reader exploring politics and policies. Londres: Lynne Rienner, 2006.

MILLER, D. C. Handbook of research design and social measurement. $5^{\text {a }}$.ed. California: Sage, 1991, cap. 2.

MOREIRA, P. G.; OLIVEIRA, A. C. V. Cruzando a fronteira: a questão das imigrações ilegais no Brasil, suas causas e impactos. Revista Observador Online, v.8, n.1, 2013.

OIM. World Migration Report - 2011. WMR, 2011. Disponível em: <http://publications.iom.int/bookstore/free/WMR2011_English.pdf〉. Acesso em: outubro de 2014. ISBN 978-92-9068-619-4.

ONU. World Economic and Social Survey. WESS, 2004. Disponível em: < http://www.un.org/en/development/desa/policy/wess/wess_archive/2004wess_part2_eng.pdf >. Acesso em: outubro de 2014. ISBN 92-1-109147-0.

PATARRA, N. L. Migrações internacionais de e para o Brasil contemporâneo: volume, fluxos, significados e políticas. Revista São Paulo em Perspectiva, v. 19, n. 3, p. 23-33, 2005.

PNUD. Relatório de Desenvolvimento Humano - 2009. RDH, 2009. Disponível em: <http://www.pnud.org.br/HDR/Relatorios-Desenvolvimento-Humano-Globais.aspx?indiceAccordion=2\&li=li_RDHGlobais\#2009>. AcesSO em: outubro de 2014. ISBN 978-972-40-3945-9.

PORTES, A. Migrações internacionais: origens, tipos e modelos de incorporação. Oeiras: Celta, 1999.

; GUARNIZO, L. E.; LANDOLT, P. The study of transnationalism: pitfalls and promise of an emergent research field. Ethnic and racial studies, v. 22, n.2, mar. 1999, p. 217-237.

RAMELLA, F. Por un uso fuerte del concepto de red en los estudios migratorios. In: BJERG, M.; OTERO, H. (Orgs), Inmigración y redes sociales en la Argentina moderna. Tandil: Cemla - IEHS, 1995. p. 9-21. 
SASSEN, S. Sociologia da Globalização. Porto Alegre: Editora Artmed, 2010.

SAYAD, A. A imigração ou os paradoxos da alteridade. São Paulo: Editora da Universidade de São Paulo, 1998.

SICILIANO, A. L. A política migratória brasileira: limites e desafios. 61 f. Dissertação (Mestrado em Relações Internacionais) - USP; São Paulo, SP, 2013.

SILVA, D. A. O Brasil nas migrações internacionais. In: SARAIVA, J. F. S.; CERVO, A. L. (Org.), $\mathbf{O}$ crescimento das relações internacionais no Brasil. Brasília: IBRI, 2005, p.111144.

TEDESCO, J. C. Modernidade e migração: o estrangeiro na globalização. In: PEREIRA, G. M. S.; PEREIRA, J. R. S. (Orgs), Migração e globalização: um olhar interdisciplinar. Curitiba: Editora CRV, 2012.

TÉLLEZ, M. E. A. Flujos migratorios em la fronteira norte mexicana: reflexiones sobre la EMIF. In: CAPELLO, H. M. (Org), Nuevos paradigmas sobre la frontera Estados Unidos-México: problemas asociados a uma larga transición. Cuernavaca: UNAM, Centro Regional de Investigaciones Multidisciplinarias, 2003.

VAINER, C. B. Migrações e mobilidade na crise contemporânea da modernização. In: HEIDEMANN, H. D.; SILVA, S. A. (Orgs), Migração: nação, lugar e dinâmicas territoriais. São Paulo: Associação Editorial Humanitas, 2007.

VERTOVEC, S. Conceiving and researching transnationalism. Ethnic and racial studies, v. 22 , n.2, mar. 1999 , p. 447-462.

ZANELli, J. C. Pesquisa qualitativa em estudos da gestão de pessoas. Estudos da Psicologia, n. 7, p. 79-88, 2002.

ZOLBERG, A. R. A nation by design: Immigration Policy in the Fashioning of America. New York: Russell Sage Foundation, 2006. 


\title{
APÊNDICE A \\ ROTEIRO DE ENTREVISTA "A"
}

(aplicado junto a dirigentes de unidades governamentais)

\begin{abstract}
Meu nome é Átila Rabelo, e sou mestrando em Relações Internacionais junto ao IREL / Universidade de Brasília. Investigo a atuação de órgãos e instituições governamentais brasileiras diante das demandas inerentes aos fluxos migratórios para o Brasil nos últimos anos, nesse início do século XXI. No caso, consideramos nessa entrevista a atuação do [menção à organização investigada]. Trata-se de uma investigação no âmbito dessa resposta institucional do Brasil às migrações internacionais ao longo da última década.

Antes de prosseguir, quero afirmar que todos os seus comentários são confidenciais, e serão utilizados apenas para fins da pesquisa. Você permite que eu grave essa conversa para análise posterior?

\{Resposta do entrevistado. Em caso positivo, continuar a gravação; em caso negativo, desligar o gravador, prosseguir com a entrevista e anotar os aspectos principais mencionados pelo entrevistado\}
\end{abstract}

Nesta entrevista, almeja-se conhecer a sua percepção acerca das demandas decorrentes desses fluxos migratórios, da atuação do [menção à organização investigada] e da articulação dessas ações com outros órgãos e instituições governamentais que atuam no âmbito das migrações. Assim, gostaria de apresentar algumas questões:

- De que forma o senhor caracteriza os fluxos migratórios para o Brasil ao longo dos últimos anos? Quais as principais demandas e/ou políticas inerentes a esses fluxos?

- Como descreve as ações implementadas pelo órgão ou unidade em que o senhor/a senhora atua no âmbito das migrações internacionais?

- Que princípios ou diretrizes norteiam a implementação dessas ações, aqui em sua unidade organizacional?

- Quais são as principais áreas e/ou unidades que estão diretamente envolvidos com o desenvolvimento e a implementação dessas ações aqui em [menção à organização investigada]?

- No ambiente externo, existe a atuação de indivíduos, entes ou outras organizações que influenciam a implementação dessas ações? Como ocorre essa participação?

- Em sua opinião, existem aspectos que facilitam o desenvolvimento e a implementação dessas ações aqui na sua unidade?

- Que tipo de desafios e/ou problemas surgem no desenvolvimento dessas ações frente aos fluxos migratórios? Comente a respeito desses desafios e/ou problemas, das lacunas envolvidas e das soluções encontradas. 
- Como avalia a articulação e a coordenação entre os órgãos e as instâncias governamentais que atuam no âmbito das migrações de pessoas para o Brasil?

- Em termos gerais, como caracteriza as tendências para as questões migratórias no Brasil em relação aos próximos anos?

- Que sugestões específicas o senhor/a senhora considera que poderiam aprimorar os esforços institucionais em prol das ações implementadas no âmbito do atendimento às demandas dos fluxos migratórios?

\section{Dados profissiográficos/biográficos:}

- Que cargo atualmente ocupa nesta unidade organizacional?

- Há quanto tempo atua em atividades relacionadas aos fluxos migratórios?

- Qual a sua formação acadêmica? (ensino superior, especialização, mestrado, doutorado) 


\title{
APÊNDICE B
}

\section{ROTEIRO DE ENTREVISTA "B"}

(aplicado junto a representantes de organizações não governamentais)

\begin{abstract}
Meu nome é Átila Rabelo, e sou mestrando em Relações Internacionais junto ao IREL / Universidade de Brasília. Investigo a atuação de instituições governamentais brasileiras diante das demandas inerentes aos fluxos migratórios para o Brasil nos últimos anos, nesse início do século XXI. No caso, consideramos nessa entrevista a atuação de instâncias como o MJ, o MTE, o MRE, o CNIg e o DPF. Trata-se de uma investigação no âmbito das respostas dessas instituições brasileiras às migrações internacionais ao longo da última década.

Antes de prosseguir, quero afirmar que todos os seus comentários são confidenciais, e serão utilizados apenas para fins da pesquisa. Você permite que eu grave essa conversa para análise posterior?
\end{abstract}

\{Resposta do entrevistado. Em caso positivo, continuar a gravação; em caso negativo, desligar o gravador, prosseguir com a entrevista e anotar os aspectos principais mencionados pelo entrevistado\}

Nesta entrevista, almeja-se conhecer a sua percepção acerca das demandas decorrentes desses fluxos migratórios, da atuação dessas instâncias governamentais e da articulação dessas ações entre órgãos que atuam no âmbito das migrações. Assim, gostaria de apresentar algumas questões:

1) De que forma o senhor caracteriza os fluxos migratórios para o Brasil ao longo da última década? Quais as principais demandas inerentes a esses fluxos?

2) Como descreve a atuação desta organização não governamental frente às questões migratórias mais relevantes nesses últimos anos?

3) Em termos gerais, como caracteriza as iniciativas do Estado brasileiro em torno do desenvolvimento de políticas efetivas em torno das migrações internacionais para o Brasil nos últimos anos?

4) Particularmente, como avalia a articulação e a coordenação entre os órgãos e as instâncias governamentais brasileiras que atuam no âmbito das migrações de pessoas para o Brasil?

5) Que sugestões específicas o senhor considera que poderiam aprimorar os esforços institucionais em prol das ações implementadas no âmbito do atendimento às demandas dos fluxos migratórios?

\section{Dados profissiográficos/biográficos:}

- Que cargo atualmente ocupa nesta unidade organizacional?

- Há quanto tempo atua em atividades relacionadas aos fluxos migratórios?

- Qual a sua formação acadêmica? (ensino superior, especialização, mestrado, doutorado) 
APÊNDICE C

INFORMAÇÕES SOBRE AS ENTREVISTAS REALIZADAS

\begin{tabular}{|c|l|c|c|}
\hline Entrevistado & Organização de que faz parte & $\begin{array}{c}\text { Data da } \\
\text { entrevista }\end{array}$ & $\begin{array}{c}\text { Duração da } \\
\text { entrevista }\end{array}$ \\
\hline 01 & DIM/DIJ/MRE & $06 / 06 / 2014$ & $1 \mathrm{~h} 10$ \\
\hline 02 & CGIg/MTE & $10 / 06 / 2014$ & $1 \mathrm{~h} 25$ \\
\hline 03 & CNIg/MTE & $30 / 07 / 2014$ & $38 \mathrm{~min}$ \\
\hline 04 & DEEST/MJ & $15 / 08 / 2014$ & $32 \mathrm{~min}$ \\
\hline 05 & OIT & $03 / 09 / 2014$ & $46 \mathrm{~min}$ \\
\hline 06 & Casa do Migrante & $10 / 09 / 2014$ & $31 \mathrm{~min}$ \\
\hline 07 & ACNUR & $22 / 09 / 2014$ & $33 \mathrm{~min}$ \\
\hline 08 & IMDH & $26 / 09 / 2014$ & $41 \mathrm{~min}$ \\
\hline 09 & OIM & $18 / 10 / 2014$ & $37 \mathrm{~min}$ \\
\hline 10 & CGPI/DPF & $23 / 10 / 2014$ & $42 \mathrm{~min}$ \\
\hline
\end{tabular}

